Please do not destroy or throw away this publication. If you have no further use for it write to the Geological Survey at Washington and ask for a frank to return it

UNITED STATES DEPARTMENT OF THE INTERIOR

Harold L. Ickes, Secretary

GEOLOGICAL SURVEY

W. C. Mendenhall, Direetor

Water-Supply Paper 773-C

\title{
ARTESIAN WATER IN THE FLORIDA PENINSULA
}

\author{
BY \\ V. T. STRINGFIELD
}

Contribntions to the hydrology of the United States, 1936

(Pages 115-195)

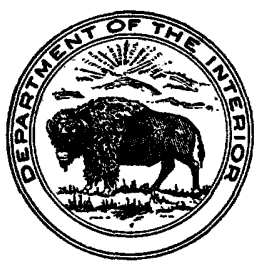

UNITED STATES

GOVERNMENT PRINTING OFFICE

WASHINGTON : 1936

For sale by the Superintendent of Documents, Washington, D. C. - - - - - Price 20 cents 


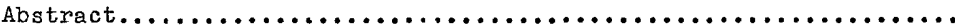

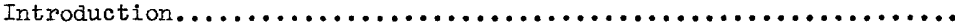

Previous reports...................................

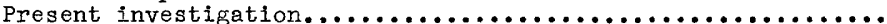

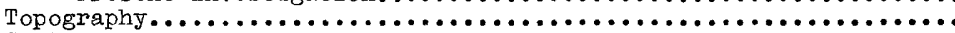

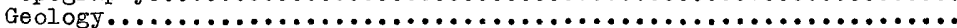

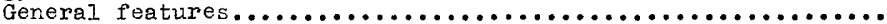

Geologic formations and their water-bearing properties.......

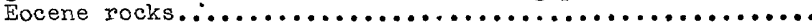

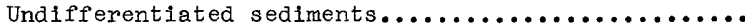

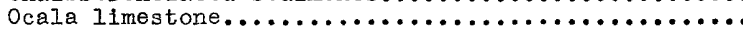

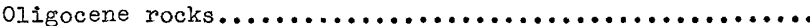

Vicksburg group...........................

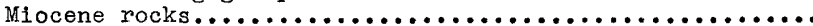

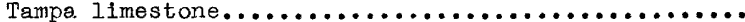

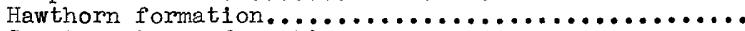

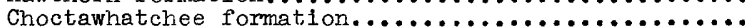

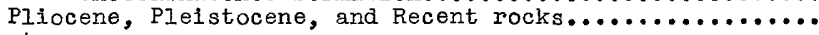

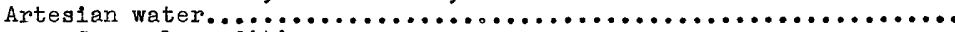

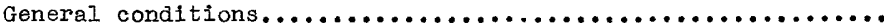

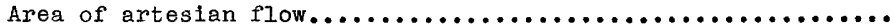

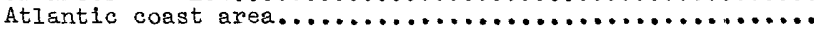

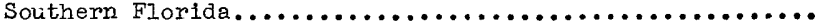

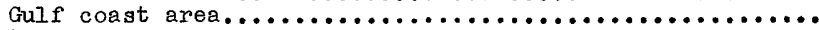

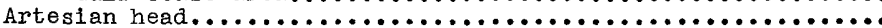

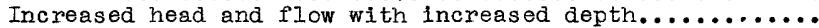

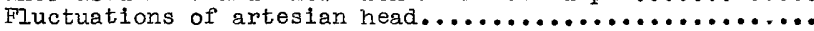

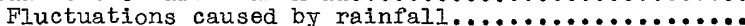

Fluctuations caused by changes in atmospheric

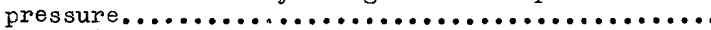

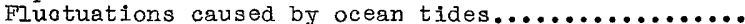

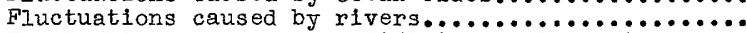

Fluctuations caused by artificial drainage into

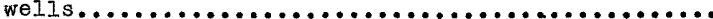

Fluctuations caused by natural artesian flow or

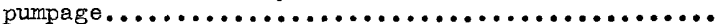

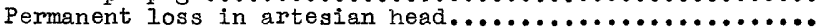

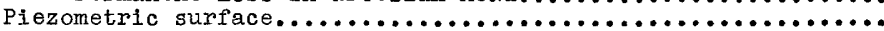

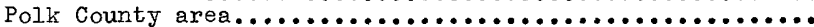

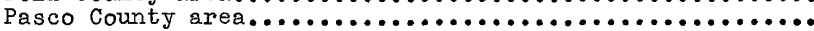

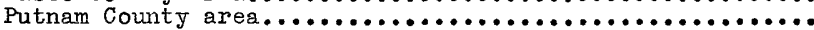

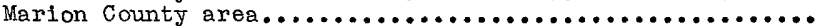

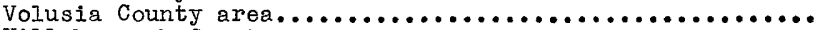

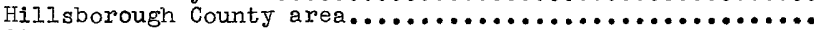

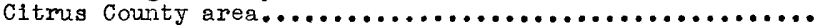

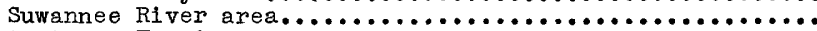

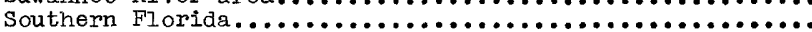

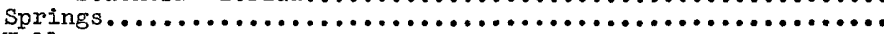

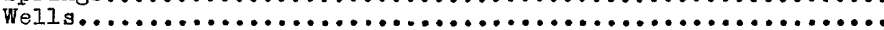

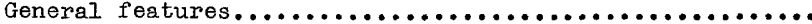

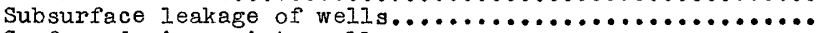

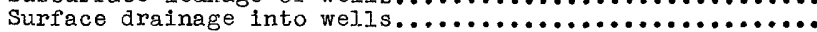

Areas of highly mineralized water and their relation to the

piezometric surface.............................

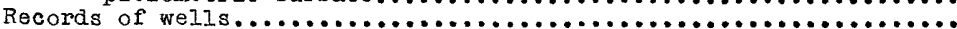

Records of measurements of pressure heads and water levels in weils

\section{ILLUSTRAT IONS}

Plate 6. Structure map of Florida peninsula..................

7. A, Exposure of about 120 feet of 0cala iimestone, show-

ing vertical solution channels or natural wells in

Crystal River rock quarry, Citrus County; B, Ocala

limestone filled with stratified clayey material in

a quarry south of Ocala, Marion County $\ldots \ldots \ldots \ldots \ldots \ldots$

8. A, old eroded surface of ocala limestone about $5 \frac{i}{2}$ miles north of Ocala, Marion County; $B$, Ocala Iimestone in quarry about $5 \frac{1}{2}$ miles north of Ocala, Marion County... 
Plate 9. A, Tampa limestone, showing bedding, in portland-cement quarry about 11 miles west of Brooksvilie, Hermando County; B, Tampa limestone, showing weathered limestone and pocket of clay, in portland-cement quarry about 11 miles west of Brooksville, Hernando County..... 128

10. Map of Florida peninsula showing areas of artesian flow... 132

11. A, Water-level recorder on well 9, Sarasota County; $B$, Water-pressure recorder on well 18, Duval County..... 134

12. Map of Florida peninsula showing piezometric surface..... 134

13. A, Silver Springs, Marion County, looking toward head of spring; $B$, Well 3 , Flagler county................... 150

14. A, Blue Springs, Marion County; B, Weekewachee Spring,

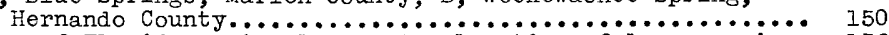

15. Map of Florida peningula showing iocation of large springs 156

16. Map of Florida peninsula showing areas in which the chloride content of the water is more than about 100 parts

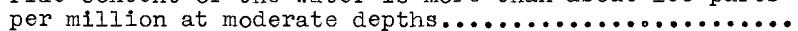
Figure 10. Sketch map of Florida and adjacent States, showing out-
line of Floridian Plateau and stracture by contour

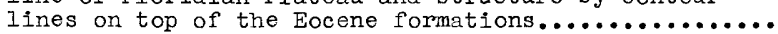

11. Fluctuations of ground-water level and rainfail in Marion County, by days, June to October $1933 . \ldots . \ldots .$.

12. Lowest water level in weil 9, Sarasota County, and rainfall at Sarasota, by days, October 1, 1930, to April

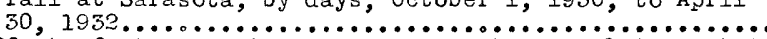

13. Effect of atmospheric pressure on water $\overline{l e v e i}$ in weil $\ddot{q}$, Sarasota County, by days, May 23 to June 12, 1931.....

14. Water level in weil 1 , Orange county, and rainfall, by

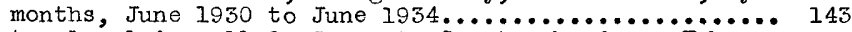

15. Water level in well 9 . Sarasota County, by days, Febmary 14 to March 3 , 1931, showing influence of draft

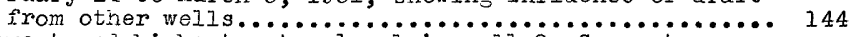

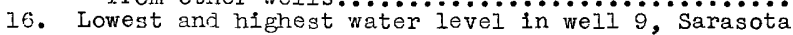
County, by months, october 1930 to March 1935........ 145

17. Profijes of piezometric surface across central and

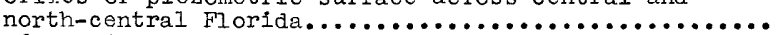

18. Profile of piezometric surface in the southern part of 
By V. T. Stringfield

\section{ABSTRACT}

Artesian water is the source of most of the large and many of the small water supplies in the Florida peninsula. The areas in which large amounts of artesian water are used include irrigation districts, as in Seminole, Manatee, and Sarasota Counties, and some of the cities, as Jacksonville. Some of the problems of the artesian supplies include (I) decline of head and of yleld of wells in areas of large draft from wells, (2) contamination of fresh artesian water by salt water, (3) subsurface leakage in wells, (4) drainage by means of wells.

The principal artesian formations are the Ocala limestone, of Eocene age, and the Tampa limestone and Hawthorm formations, of Miocene age. The older rocks underlying these formations are not important sources of water at present, because they are deeply buried in a large part of the peninsula and in some places contain highly mineralized water. The younger rocks, overlying the artesian formations, constitute the main source of nonartesian ground water. The Ocala and Tampa formations consist essentially of limestone, pert of which is porous and contains cavities. They contain large amounts of water and are the source of some of the largest limestone springs in the United States. The Ocala underlies the entire peninsula and crops out in the northwestern part. It has an estimated thickness of about 500 feet, overlies older undifferentiated Eocene rocks, and underlies the Tampa limestone. The Tampa underlies part of the peninsula and crops out in the northwesterm part. It has an estimated thickness of about 200 feet. The Hawthorn formation consists of about 500 feet of interbedded marl, limestone, clay, and sand. It rests on the Ocale Ilmestone in some localities and on the Tampa limestone in others. It underlies the entire peninsula except where the Ocala or Tampa is at or near the surface. In the southerm part of the peningula it is overlain by a considerable thickness of younger material. These formations are bent into an anticline that trends northward through the peninsule and plunges toward the south. The crest of the anticline is in the northwesterm part, where the Ocala limestone is estimated to be as much as 120 feet above sea level. The structure is favorable for artesian conditions, which are present throughout the peninsula except locally in recharge areas. In part of the area, however, the artesian conditions and the movement of the water are independent of the structure. The wells that are supplied from the artesian formations range in depth from less then 100 feet to more than 1,000 feet and in yield from a few gallons to several thousand gallons a minute. The areas in which wells will overflow at the surface lie chiefly along the coasta and in the southerm part of Florida. The helght to which water will rise above the surface of the ground ranges from a fraction of a foot to about 45 feet. In nonflowing wells in the higher areas the water may stand as much as 100 feet below the surface. The height above sea level to which artesian water will rise ranges from a few feet in some areas on or near the coast to 120 feet in the central part of the peninsula. Recorded fluctuations of head range from less than a foot to several feet. Some of the causes of these fluctuations are withdrawal of water from wells either by natural flow or pumpage, rainfall, discharge of surface water into drainage wells, ocean tides, changes in barometric pressure, and fluctuations of river levels.

The contour map representing the piezometric surface, or height above sea level to which water would rise in tightly cased wells, in 1934 Indicates the areas of large recharge and of large discharge, the hydraulic gradient, and the direction of movement of the water. The principal areas of recharge are in the central, north-central, and northwesterm parts of the peninsula and one area in Georgia that supplies part of the water for northern Florida. They include areas in which the artesian formations are at or near the surface, areas where sink holes extend from the surface to the artesian formations, and areas where drainage wells penetrate the artesian formations. The principal areas of natural discharge of artesian water are in the north-central and northwesterm parts of the peningula. ITis discharge occurs through large springs and seepages, some of which are submarine. The area of most obvious influence of natural discharge on the plezometric surface is in the north-central part of the peninsula, where the piezometric surface forms a low saddie that slopes to only a few feet above sea level along the coasts. One of the areas of most obvious influence of draft from wells on the piezometric surface is in Jacksonville and viloinity. 
Artesian water that contains more than 100 parts per million of chloride is present at moderate depths in parts of the coastal areas and in the valley of the St. Johns River, where the artesian pressure is small, and also in part of southern Florida. In some areas the pressure on the artesian water is great enough to cause the water to discharge into the ocean through submarine springs, and no encroachment of sea water is occurring now, but encroachment may occur if the pressure is lowered sufficiently. Some of the water is contaminated by salt water or mineral salts in the formation and not by the encroachment of sea water.

\section{INTRODUCTION}

\section{Previous reports}

The geology and ground water of Florida are described in several reports prepared by the State Geological Survey of Florida and the United States Geological Survey. One of the earliest of these is a report by Sel1 lards relating to the artesian water of central Florida. A report by Mat2 son and Sanford, published in 1913, is one of the most comprehensive reports on the ground water of the entire state. In the same year a report by Sel3 lards and Gunter on the artestan water of eastern and southern Florida was published. General information regarding the ground water is included in several later reports published by the Florida Geological survey. 4 The report by Gunter and Ponton Includes maps of the artesian water in part of the area. A detalled report on the artesian water in Sarasota County was published in 1933. A paper prepared by Collins and Howard includes a discussion and analyses of artesian water of the Florida peninsula.

The most complete description of the geology of the peninsula is given 7 in a report by Cooke and Mossom, which includes a geologic map showing the distribution of the geologic formations at or near the surface. A report by Mossom describes the geologic structure of the State.

1 Sellards, E. H., A preliminary report on the underground water supply of central Fiorida: Flortda Geol. Survey Bull. 1, 1908.

2 Matson, G. C., and Sanford, Samuel, Geology and ground waters of Florida: U. S. Geol. Survey Water-Supply Paper 319, 1913.

3 Seliards, E. H., and Gunter, Herman, The artestan water supply of eastern and southern Florida: Florida Geol. Survey 5th Ann. Rept., pp. 103$290,1913$.

4 Gunter, Herman, and Ponton, G. M. Need for conservation and protection of our water supply with special reference to waters from the Ocala limestone: Florida Geol. Survey 22d Ann. Rept., pp. 43-55, 1931. Thompson, D. G., and Stringfield, V. T. Ground-water resources of Fiorlda: Florida Geol. Survey Press Buli. 13, 1931. Stringfleld, V. T., Ground-water Investigations in Florlda: Fíorida Geol. Survey Buli. ii, 1933; Ground water in Seminole County, Fla.: Florida State Board Cons., Geol. Dept., Rept. I, 1934.

5 Stringfield, V. T., Ground-water resources of Sarasota County:

Florlda Geol. Survey 23d-24th Ann. Rept., pp. 121-194, 1933.

6 Collins, W. D., and Howard, C. S., Chemlcal character of the water of Florida: U. S. Geol. Survey Water-Supply Paper 596-G, pp. 177-233, 1928.

7 Cooke, C. W., and Mossom, Stuart, Geology of Flortda: Florida Geol. Survey 20th Ann. Rept., pp. 29-22́8, 1929.

8 Mossom, Stuart, A review of the stmucture and stratigraphy of Florlda: Florida Geol. Survey 17th Ann. Rept., pp. 171-219, 1926. 
A report of the U. S. Engineer office at Jacksonville contains information regarding the geology and ground water of the central and northern parts of the peninsula. It includes a map described as representing the water table in part of the peninsula. An unpublished report prepared for the water-supply commission of Jacksonville contains a map representing the artesian water in Jacksonville and vicinity and a map with generalized contours described as representing the ground-water table in the peninsula.

\section{Present investigation}

In recent years there have been new developments of ground-water supplies in Florida, and the consumption of water in some areas has steadily increased. Similar increases may be expected in the future. The yleld of wells has decreased as a result of heavy draft in some localities. In certain areas near the coast the decrease in head has permitted salt water tc enter the wells and contaminate the fresh-water supply to such an extent that it has been necessary to abandon the wells and develop new supplies. In other areas no salt-water encroachment has jet taken place, but with heavy draft from wells it may occur in the future. Among other problems are those that arise from subsurface leakage of water in improperly cased wells and the use of wells for dralnage of surface water into the underlying rocks.

In order to facilitate a better understanding and interpretation of hydrologic conditions relating to these local ground-water problems, a general survey of the artesian water in the Florida peninsula was undertaken in 1934, and this report is based chiefly on the results of that work. The investigation was under the direction of 0. E. Meinzer, geologist in charge of the division of ground-water work of the United States Geological Survey. The writer was in charge of the field work and spent about 8 months on 1t. Frank Westendick, assigned to the United States Geological Survey for the investigation, spent about 12 months in the fleld collecting data over a large part of the area. D. G. Thompson made valuable suggestions regarding the fleld work. Herman Gunter, State geologist of Florlda, gave hearty and valuable cooperation. Many of-

9 Geology and ground water (Appendix B, Waterway from Cumberland Sound, Georgla and Florida, to the MIssissippi RIver), manuscript report of Special Board, U. S. Engineer office, Jacksonville, Fla., Dec. 30, 1933.

10 Pirnie, Malcolm, Investigations to determine the source and sufficlency of the supply of water in the Ocala limestone as a municipal supply for Jacksonville, New York, Hazen \& Whipple, 1927. 
ficials, owners of wells, and others furnished information that made the progress of the investigation possible.

As a result of the investigation maps were prepared representing the head of the artesian water in the peninsula and the general areal extent of the highly mineralized water. The artesian map shows by contours the height to which water would rise above sea level in tightly cased wells In 1934. These contours indicate the areas of recharge, the areas of large discharge, the hydraulic gradient, and the direction of movement of the artesian water and aid in the explanation of the present distribution of the highly mineralized water.

\section{TOPOGRAPHY}

The topography of the Florida peninsula is described in a report by Matson and Sanford, which includes a generalized topographic map. It is also briefly described by Cooke and Mossom in a more recent publication. The United States Geological Survey has published detailed topographic maps of nine quadrangles in the north-central part of the peninsula and of fifteen quadrangles in the northeastern part of Florida and the adjacent part of Georgia.

Although the altitudes range only from sea level to about 300 feet, the topography presents considerable diversity. An upland, much of which is hilly, extends as a central ridge from the northern part of the peninsula to southern Highlands County. West of the central ridge is another irregular hilly area, which lies chiefly in Pasco, Hernando, and Citrus Counties. Much of the upland area contains numerous sink holes or other depressions and lakes that range in diameter from a few feet to several miles. The sink holes formed by the removal of underlying soluble limestone by ground water are typically developed in such areas as Alachua, Marion, and Citrus Counties. Lakes occupying depressions, part of which are probably old sink holes, are abundant in Lake and Polk Counties, which are within an area often referred to as the "lake region." Topography of this type bears an important relation to ground water, because it was formed chiefly by the action of ground water on the soluble underlying limestone and because surface water enters the formation through the sinks and lakes, thus recharging the water-bearing rocks, even though they may not be present at the surface.

11 Matson, G. C., and Sanford, Samuel, op. c1t., pp. 21-65, pl. 1. 12 Cooke, C. W., and Mossom, Stuart, op. cit., pp. 42, 43 . 
Adjacent to and bordering the upland sections are plains or terraces extending to the coast. As described by Cooke and Mossom, 13 "plains cover more than half of the State of Florida. Most of them are either coastal terraces, which are former sea bottoms, or drained lake basins. Terraces occupy the southern third of the peninsula and extend inland for considerable distances along both the east and the west coast. Most of the terraces on the west side of the peninsula north of Tampa are * * floored by Iimestone of Eocene and Miocene age, which are covered by only a thin veneer of Plelstocene or Recent sand. The terraces along the Atlantic coast have been built up by the sea, but farther inland erosion has been dominant. The terraces range in altitude from sea level to 200 feet or more above sea level."

\section{GEOLOGY}

\section{General features}

The Florida peninsula is underlain by 4,000 feet or more of sedimentary rocks that overlie a basement of metamorphic rocks. The formations exposed at the surface in different parts of the peninsula probably represent about 1,000 to 1,500 feet of the geologic section and include the Ocala limestone, of Eocene age, and younger formations of Miocene, Pliocene, Pleistocene, and Recent age. These formations yield the groundwater supplies. The sedimentary rocks older than the Ocala probably represent formations of Eocene and Cretaceous age but at the present time are not of importance as a source of potable water supplies because they are deeply buried and in mach of the area contain highly mineralized water.

According to Cooke and Mossom, "the oldest rocks in Florida of which there is any record are mica schists and quartzite that are reached by a deep well in Marion County but do not occur at the surface anywhere in the state. Although little is known about them by direct examination, it can be inferred that they form part of the great series of metamorphic and Igneous rocks that make up the Piedmont Plateau of Alabama, Georgia, and other Eastern States and that underlie the sediments of the Atlantic Coastal Plain wherever the sediments have been cut through by streams or penetrated by wells. Bedrock of this kind may underlie the entire State

13 Cooke, C. W., and Mossom, Stuart, op. cit., p. 43.

14 Idem, p. 44 . 
of Florida and extend beyond the shore line to the edge of the Floridian Plateau."*

Florida forms the emerged part of the Florldian Plateau, ${ }^{15}$ a peningula that separates the deep water of the Gulf of Mexico from the deep water of the Atlantic Ocean. The plateau includes not only the state of Florida but also part of the adjacent ocean floor that is less than 60 fathoms (300 feet) below sea level.

The outline of the plateau is shown in figure 10. Beyond a depth of 50 fathoms the ocean floor slopes abruptly to depths of more than 400 fathoms in the Straits of Florida and the Atlantic Ocean and more than 2,000 fathoms in the Gulf of Mexico. The edge of the plateau in the Gulf Iles

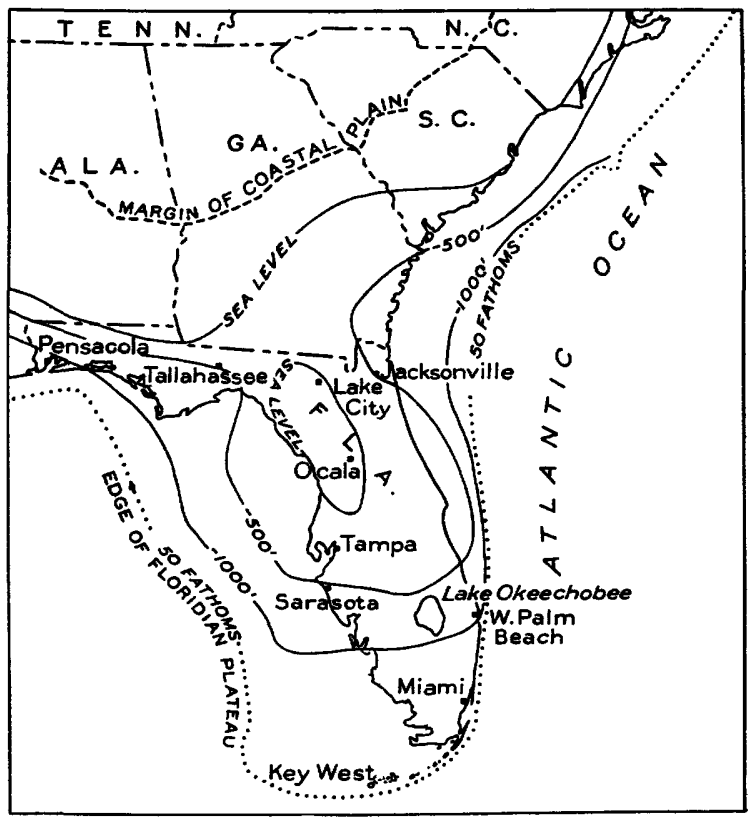

Figure 10.- Sketch map of Florida and adjacent States showing outline of Floridian Plateau and structure by contour lines on top of the Focene formation. (From State geologic map of Florida.)

from somewhat less than 75 miles to more than 100 miles west of the present coast of the Florida peninsula. Along the south and east coast of the peninsula from Key Weat to Palm Beach the edge of the Platean is lesa than 20.mles from the coast. Along the northerm part of the peninsula it is about 60 to $80 \mathrm{miles}$ east of the coast.

15 Cooke, C. W., and Mossom, Stuart, op. clt., p. 39. Vaughan, T. W., A contribution to the geologic history of the Floridian Platedu: Carnegie Inst. Washington Pub. 133, pp. 99-185, 1910. 


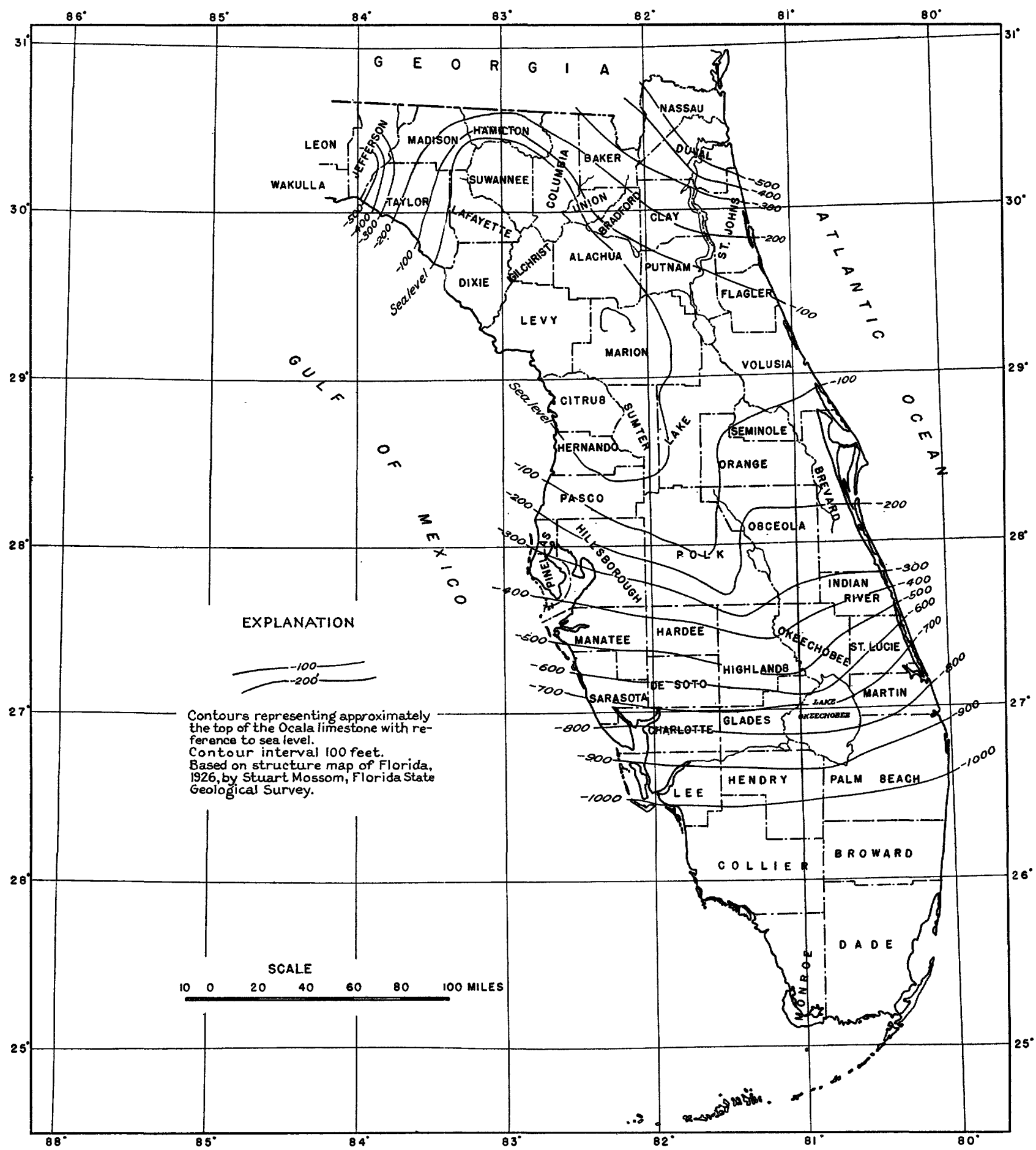

STRUCTURE MAP OF THE FLORIDA PENINSULA. 
The sedimentary rocks that overlie the basement rocks of the plateau are arched into a broad anticline or elongated dome that trends northwestward and plunges toward the southeast in the southern part of the Florida peninsula. The general features of this anticline are shown in plate 6 , and a report by Mossom ${ }^{16}$ contains a map and a description of it.

The crest of the fold is in the northwestern part of the peninsula, where the Ocala limestone lies at or near the surface. On some parts of the crest the Ocala is as much as 120 feet above sea level. It dips under the younger formations exposed on the flanks of the fold. This fold affords structural features favorable for artesian conditions. The formations on its flanks dip at low angles toward the Atlantic Ocean and the Gulf of Mexico. They crop out on the floor of the ocean or gulf some distance offshore, and some of them probably crop out on the edge of the Floridian Plateau.

\section{Geologic formations and their water-bearing properties}

The following table represents the formations that underlie the Florida Peninsula. The Ocala limestone and overlying younger formations are exposed at the surface in parts of the peninsula. The formations underlying the Ocala do not crop out and are known only through cuttings and records of wells that penetrate them. 
Geologic formations in the Florida peninsula

\begin{tabular}{|c|c|c|c|}
\hline Age & Formation & $\begin{array}{l}\text { Estimated } \\
\text { thickness } \\
\text { (feet) }\end{array}$ & Character \\
\hline $\begin{array}{l}\text { Recent } \\
\text { and } \\
\text { P1elstocene. }\end{array}$ & & $0-200 ?$ & $\begin{array}{l}\text { Undifferentiated sand and solis. } \\
\text { Yleld water to shallow wells. }\end{array}$ \\
\hline \multirow{3}{*}{ Pleistocene. } & Melboume bone bed. & $0-10$ & $\begin{array}{l}\text { Chiefly sand with characteristic } \\
\text { vertebrate fauna. }\end{array}$ \\
\hline & $\begin{array}{l}\text { Fort Thompson formation (contem- } \\
\text { poraneous with Miami oolite). }\end{array}$ & $0-10$ & $\begin{array}{l}\text { Sand, marl, and limestone rield } \\
\text { water to shallow wells. }\end{array}$ \\
\hline & \begin{tabular}{c|c|c|} 
Anastasia & Miami & Key Largo \\
formation. & oolite. & Imestone \\
\end{tabular} & $0-30 ?$ & $\begin{array}{l}\text { Coquina and limestone. Yleld water } \\
\text { to shallow wells. }\end{array}$ \\
\hline Pliocene(?). & Charlton formation. & $0-20$ & Limestone and clay. \\
\hline \multirow{3}{*}{ P11ocene. } & $\begin{array}{l}\text { Citronelle formation (exact strat- } \\
\text { Igraphic position uncertain). }\end{array}$ & $0-250\}$ & $\begin{array}{l}\text { Sand, gravel, and clay. Yields } \\
\text { water to shallow welis. }\end{array}$ \\
\hline & $\begin{array}{l}\text { Caloosahatchee marl (contemporaneous } \\
\text { with Alachua formation and Bone } \\
\text { Valley gravel). }\end{array}$ & $10-100$ & $\begin{array}{l}\text { Sand, shell, and marl. Yields } \\
\text { water to shallow weils. Some of } \\
\text { the water is highly mineralized. }\end{array}$ \\
\hline & $\begin{array}{l}\text { Alachua } \\
\text { formation. } \\
\text { gravel. }\end{array}$ & $0-50$ & Sand, clay, and phosphate. \\
\hline \multirow{3}{*}{ Mocene. } & Choctawhatchee formation. & $0-50 ?$ & Clay and marl. \\
\hline & $\begin{array}{l}\text { Hawthom formation } \\
\text { (of Alum Bluff group). }\end{array}$ & $0-500$ & $\begin{array}{l}\text { Interbedded sand, clay, marl, and } \\
\text { limestone. Important source of } \\
\text { water, part of which 1s under } \\
\text { artesian pressure. Locally in } \\
\text { some areas near the coast the } \\
\text { water is highly mineralized. }\end{array}$ \\
\hline & Tampa Iimestone. & $0-250$ & $\begin{array}{l}\text { Limestone. Important source of } \\
\text { water, mach of which is under } \\
\text { artesian pressure. Locelly in } \\
\text { some areas near the coast the } \\
\text { water is highly mineralized. }\end{array}$ \\
\hline oligocene. & $\begin{array}{l}\text { May be represented by a small } \\
\text { thickess of limestone (of } \\
\text { Vicksburg group) exposed on } \\
\text { the Suwannee River and in- } \\
\text { cluded in the base of the } \\
\text { Tampa limestone. }\end{array}$ & $0-70 ?$ & Limestone. \\
\hline \multirow[t]{2}{*}{ Eocene. } & Ocala limestone. & $500 \pm$ & $\begin{array}{l}\text { Limestone. Important source of } \\
\text { water, a large part of which is } \\
\text { under artesian pressure. Some } \\
\text { of the water is highly miner- } \\
\text { alized. }\end{array}$ \\
\hline & older Eocene. & & Deeply buried. \\
\hline \multicolumn{2}{|c|}{ Eocene- and Cretaceous. } & & $\begin{array}{l}\text { Undifferentiated sedimentary rocks } \\
\text { deeply burled; contain miner- } \\
\text { alized water. }\end{array}$ \\
\hline \multicolumn{2}{|c|}{ Paleozolc or older. } & & $\begin{array}{l}\text { Mica schist and quartzite. Meta- } \\
\text { morphic basement rocks, doeply } \\
\text { buried. }\end{array}$ \\
\hline
\end{tabular}




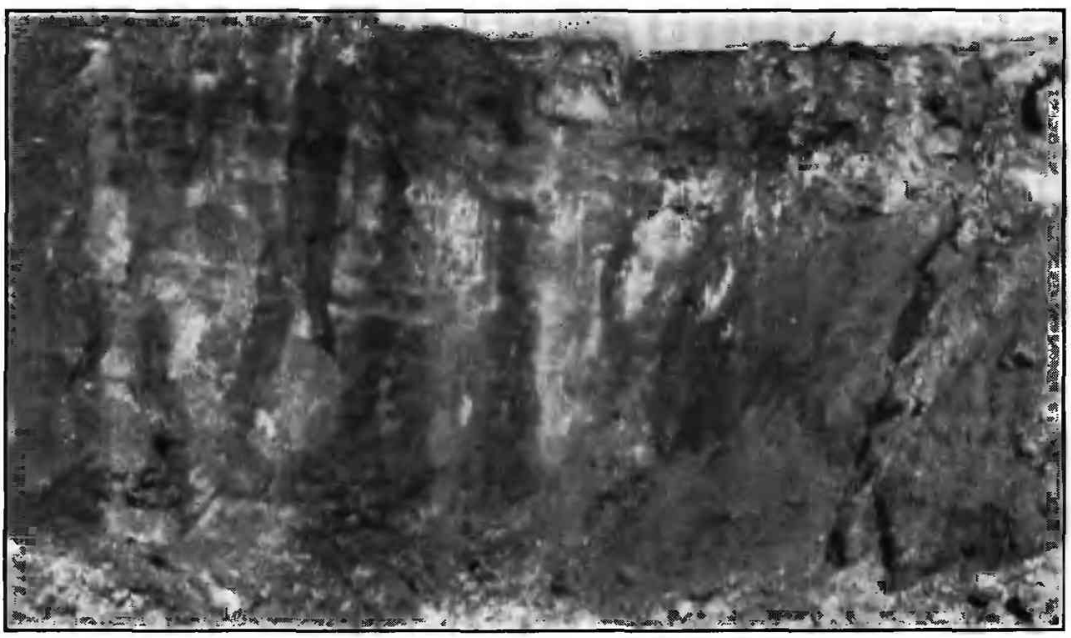

A. EXPOSURE OF ABOUT 120 FEET OF OCALA LIMESTONE.

Showing vertical solution channels or natural wells in Crystal River rock quarry, Citrus County.

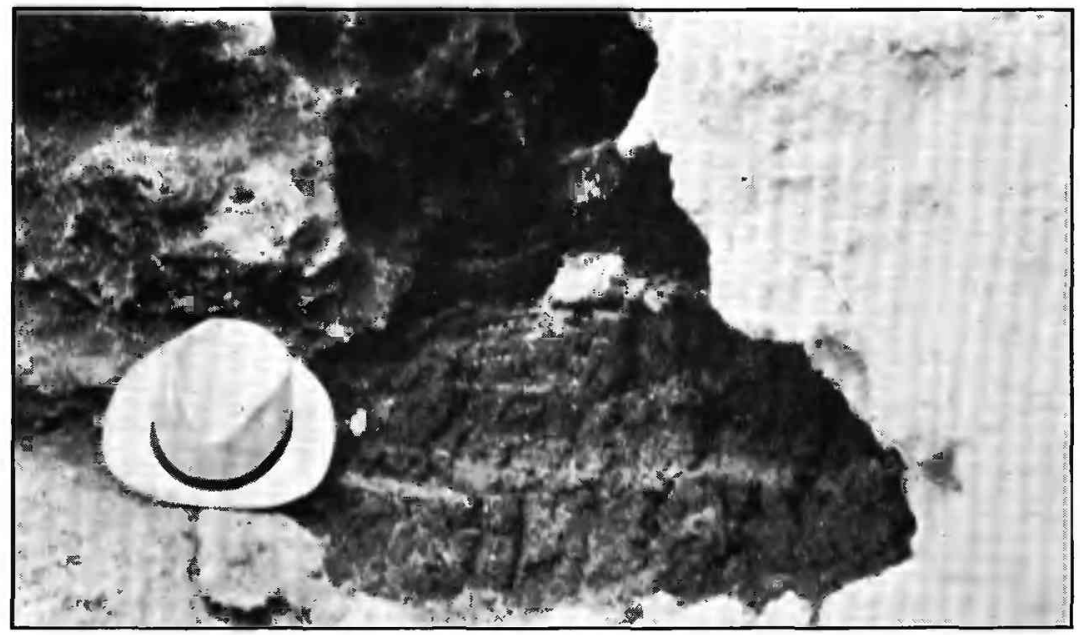

B. EXPOSURE OF OCALA LIMFSTONE FILLED WITH STRATIFIED CLAYEY MATERIAL. In a quarry south of Ocala, Marion County. 


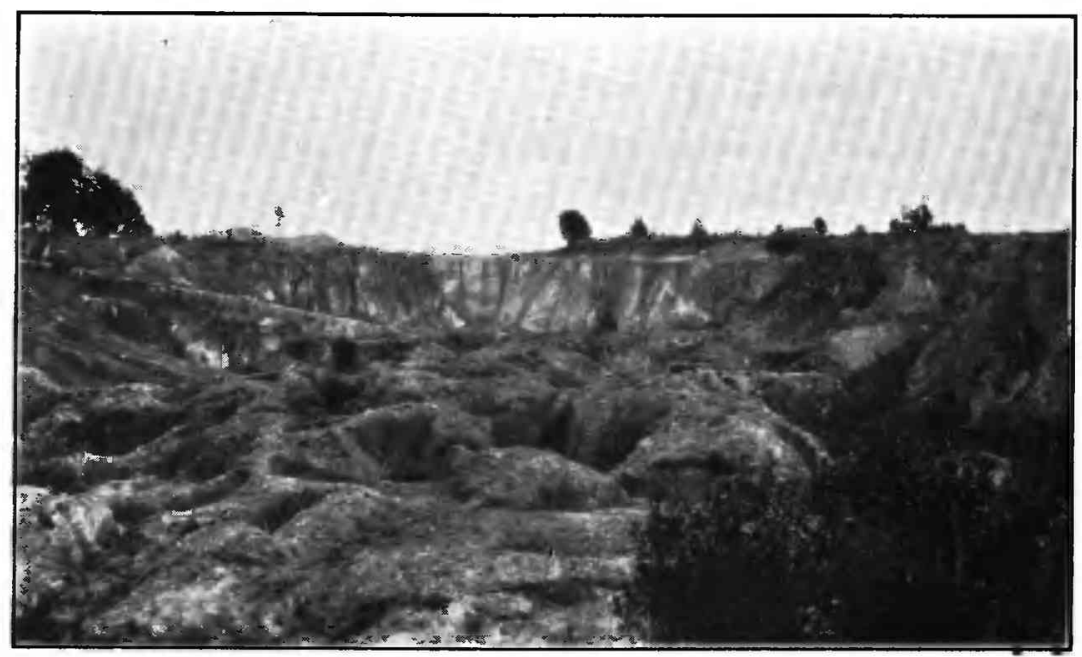

A. OCALA LIMESTONE SHOWING OLD ERODED SURFACE ABOUT $51 / 2$ MLES NORTH OF OCALA, MARION COUNTY.

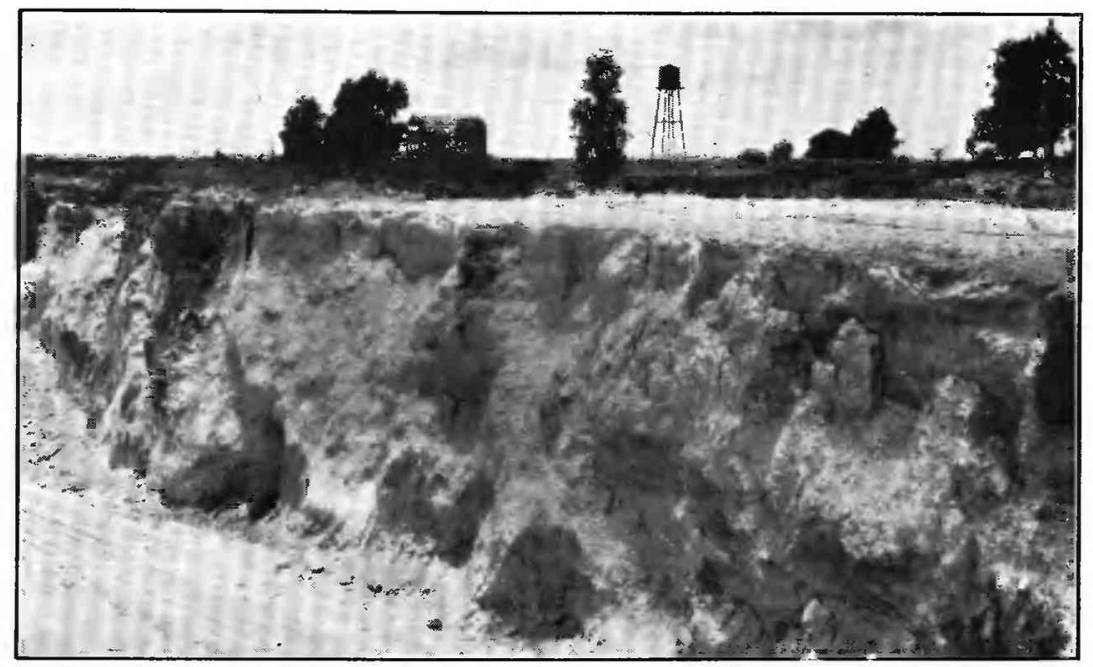

B. OCALA LIMESTONE IN QUARRY ABOUT 51/2 MILES NORTH OF OCALA, MARION COUNTY. 


\section{Eocene rocks}

\section{Undifferentiated sediments}

According to the correlation of the cuttings from a well of the Ocala 011 Corporation in sec. 10, T. 16 S., R. 20 F., south of York, in Marion County, by Gunter and Ponton, the Eocene rocks are represented in that well by about 3,260 feet of material consisting chiefly of limestone, with some gypsum, lignite, and clay, and the underlying Cretaceous rocks by about 840 feet of material, chiefly limestone and chalk, with some shale. The upper part of the Eocene rocks is assigned to the Ocala limestone, which is the oldest formation exposed at the surface in the state. In a correlation of the cuttings and the following well $\log ^{18}$ Cooke and Mossom placed the contact of the Ocala limestone and the underlying undifferentlated Eocene sediments at a depth of 570 feet.

\section{Cuttings from a well of the Ocala 011 Comporation, south of York}

Eocene: Ocala limestone, in part:

Feet

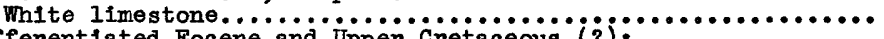

Undifferentlated Eocene and Upper Cretaceous $(i)$

Brownish porous limestone and vitreous flint................

Brownish finely granular limestone resembling brown sugar....

Dark-brown carbonaceous clay...........................

Brown sugary limestone...............................

carbonaceous clay............................ 880-920

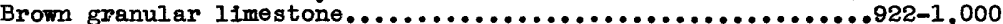

White chalky limestone.............................. $1,000-1,165$

Brown granular 1imestone............................. 1,165-1,280

Compact brownish Iimestone.......................... 1,280-1,400

Light-brown granular limestone....................... 1,400-1,600

White limestone containing many smail Foraminifera......... $1,600-1,850$

White calcareous clay.............................. 1,850-2,200

White limestone containing smail Poraminifera ( 2 samples). $2,200-2,350$

White anhydrite.................................. 2,350-2,370

White limestone containing smali Foraminifera............ 2,370-2,400

Soft white chalky limestone........................... 2,400-2,450 Light-brown limestone (3 samples at 100-foot intervals)... 2,450-2,700

White calcareous mud................................ 2,700-3,600

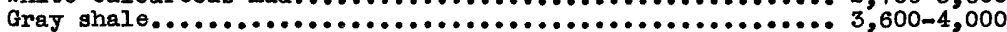

Probably Paleozoic or older:

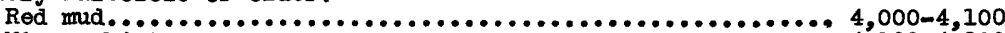

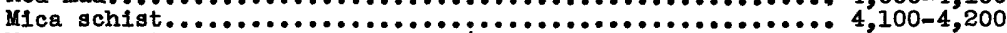

Mica schist and granular quartz ( 3 samples at $100-f o o t$

Intervals ).....................................4,200-4,500 White quartzite $(i 1$ semples) .......................... 4,500-6,180

Only a few of the deeper wells arliled for water in the peninsula extend into the undifferentiated sedimentary rocks. The upper part is probably comparable to the lower part of the overlying Ocala limestone.

17 Gunter, Herman, and Ponton, G. M., Need for conservation and protection of our water supply with special reference to the waters from the Ocala limestone: Florida Geol. Survey 2lst-22d Ann. Repts., for 1929-30, p. 49,1931 .

is Cooke, C. W., and Mossom, Stuart, op. c1t., pp. 44-45. 


\section{Ocala limestone}

The name "Ocala limestone" was first used by Dall in 1892 for the

tNummulitic limestone 20 exposed at the surface and in quarries in the vicinity of Ocala, in Marion County. The name is now applied to all Eocene rocks exposed in Florida.

The Ocala limestone underlies all of the Florida peninsula and lies at or near the surface in the northwestern part of the peninsula adjacent to the Gulf of Mexico. That area includes all or parts of Sumter, Hernando, Citrus, Marion, Levy, Alachua, Dixie, Gilchrist, Lafayette, and Suwannee Counties. In the northeastern part of the peninsula the Ocala is about 500 feet below the surface; in the southern part, 1,000 feet or more. The general position of the top of the formation with reference to sea level is indicated in plate 6 .

The formation consists essentially of limestone and is reported to have a thickness of at least 500 feet in the northern part of the peninsula and possibly is much thicker in the southern part. Predominantly the limestone is fairly soft and porous, some of it consisting entirely of remains of small fossil organisms. Part of the limestone, however, is dense and compact. Bedding planes are absent in exposed sections. In areas where the formation crops out the limestone ranges in color from wite to yellow and brown. Circulation of water through parts of the formation has formed cavities and caverns, especially were it is at or near the surface. In these areas sink holes are mumerous, and also cylindrical holes or natural wells, ranging from a fraction of a foot to more than 5 feet in diameter and from a fer feet to more than 50 feet in depth (pl. 7, A), that lead downward from the surface and connect with underground passages that represent former water levels in the rocks. Some of the passages are now interconnected with the present ground-water level. Solution channels formerly occupled by ground water but now filled with sand and clay are exposed in some of the limestone quarries in Marion County. An exposure of a small channel filled with clajey material is shown in plate 7, B. One of the largest channels ob-

$19 \mathrm{Dall}, \mathrm{W} . \mathrm{H}_{.}$, and Harris, G. D., Correlation papers - Neocene: U. S. Geol. Survey Búll. 84, pp.'103-104, 1892 .

20 A dagger $(\boldsymbol{T})$ preceding a geologic name indicates that the name has been abandoned or rejected for use in classification in publications of the U. S. Geological Survey. Quotation marks, formerly used to indicate abandoned or rejected names, are now used only in the ordinary sense.

21 Cooke, C. W., and Mossom, Stuart, op. c1t., p. 47.

22 Idem, p. 48. 
served, about 12 feet wide and 6 feet high, in Marion County, is filled chiefly with white quartz sand and some gray clay. It has a fairly flat floor and an arched roof. According to reports by drillers, many of the wells penetrating the Ocala limestone in the central part of Florida encounter cavities as much as 20 feet high, but in the southerm part of the peninsula, where the limestone is deeply buried, no cavities have been reported. Recently exposed surfaces of the Ocala show an old erosion surface at the top of the formation. (See pl. 8, A.) Records of wells indicate that old stream channels have cut into the formation to depths of more than 100 feet below the present sea level. Also, some sink holes, formerly several hundred feet deep but now filled with sand, are present.

Secondary deposition of silica, as layers or irregular masses of chert, has accompanied the leaching and solution of the limestone at many places. Such replacement is usually most extensive near the surface, but chert has been encountered at considerable depths in wells. The chert and silicified limestone are usually noticed by well drillers because they are much harder than other parts of the formation.

In different parts of the peninsula the Ocala limestone is overlain unconformably by the Tampa limestone, the Hawthorm formation, or younger material. In the northeasterm part of the peninsula it is overlain directly by the Hawthorm formation. Older unexposed Eocene rocks underlie the Ocala.

The lithology of the Ocala and the underlying Eocene rocks is sim1lar, and it is therefore necessary to distinguish the two units on the basis of a study of fossils collected from the well cuttings. No diagnostic fossils have been reported near the contact, and the lower limit of the 0cala has therefore not been definitely determined.

The Ocala limestone is one of the chief water-bearing formations of the peninsula because of its wide extent and its capacity to yield large quantities of water to wells. In parts of the formation the water occurs in caverns or cavities. Much of the limestone is so porous that water percolates freely through 1t. The chert and silicified limestone are relatively impervious and do not yield water to wells, but water is commonly encountered 1mmediately beneath these rocks. The capacity of the ocala formation to yield water to wells is less in the southerm part of the peninsula than in the central part. Some of the wells in Sarasota County that penetrate the Ocala limestone yield little or no 
water from that formation. 23 The Ocala contains water under artesian pressure that is confined by relatively impervious rocks of overlying formations and also by relatively impervious limestone and chert within the Ocala itself. It supplies water for many of the wells in the peninsula (se日 table at end of the report) and is the source of water for many of the public supplies. The public water supply for the city of Jacksonville, one of the largest supplies in the State, is obtained from wells penetrating the Ocala. The formation is the source of some of the large springs, such as silver Springs, in Marion County. In the southern part of the peninsula, however, the formation supplies few wells because of its great depth below the surface, its relatively small yield of water, and the saline water present in that part of the formation.

The fresh water of the ocala enters the formation in areas where it is exposed at or near the surface in the central part of the peninsula and in other places where it is overlain by permeable material that permits downward percolation of the water.

\section{Oligocene rocks}

\section{Vicksburg group}

In Florida, rocks of Oligocene age are referred to the Vicksburg group, which in the northwestern part of the state is represented by the Marianna limestone, the Byram marl, and the Filint River formation. 24 The Flint River formation is believed to correspond to the upper part of the Byram marl. The Glendon limestone, which in southerm Alabama and Mississippi underlies the Byram marl, was formerly supposed to be present in northern Florida also, ${ }^{26}$ but more recent work by Cooke has led him to doubt the presence of the Glendon in Florida, and the beds in southwestern Georgia and northerm Florida that were formerly called "Glendon" have recently been named by him "Flint River formation." At present no representative of the Vicksburg group is known to occur in the Florida peninsula, but it is considered probable by Cooke that the limestone exposed on the Suwannee River and now treated as the basal bed of the Tampa limestone may in reality be of vicksburg age.

23 Stringfield, V. T., Exploration of artesian wells in Sarasota County: Florida Geol. Survey 23d-24th Ann. Rept., pp. 199-227, 1933. 24 Cooke, C. W., Notes on the Vicksburg group: Am. Assoc. Petroleum Geologists Bull:, vol. 19, No. 8, p. 1170, 1935. 25 Idem, $p_{.} 1171$.

26 Cooke, C. W., and Mossom, Stuart, op. cit., pp. 68, 72.

27 Cooke, C. W., op. cit., pp. 1170-117i. 


\section{Miocene rocks}

The Miocene rocks in the Florlda peninsula are represented by the Tampa Ilmestone and the Hawthorn formation. The Hawthom belongs to the Alum Bluff group and is probably contemporaneous with the Chipola formation, the lowest formation of the Alum Bluff group of western Florida.

\section{Tampa Ilmestone}

The name "Tampa Iimestone" was used by $\mathrm{Dall}^{28}$ in 1892 , in describing rocks exposed at Ballast Point, near Tampa. A more recent conception of the formation includes Dall's Tampa Iimestone and, as mapped by Cooke and Mossom, not only the Tampa of early workers but most of the Chattachoochee and part of the Hawthorn formation of Matson and Clapp.

The Tampa limestone lies at or near the surface in an area that includes all or parts of Hillsborough, Pinellas, Pasco, Hernando, Sumter, and Citrus Counties, also in the northwestern part of the peninsula and in erosion remnants in a few areas where the 0cala limestone is near the surface. Well records indicate that the Tampa limestone is absent in the eastern and northeastern parts of the peninsula. The position of the Tampa limestone with reference to sea level may be estimated approximately by referring to plate 6 , which represents by contours the position of the top of the Ocala Iimestone.

According to Cooke and Mossom the Tampa limestone is apparently not more than 100 feet thick in the vicinity of Tampa, although Matson and 31

Clapp report the maximum thickness in that vicinity as more than 130 feet. Cooke states that the Tampa is about 100 feet thick near Iive 0ak, In Suwannee County. Records of wells near Lake City, in Columbia County, Indicate that the Tampa in that county is less than 100 feet thick and is locally absent. Wells in the northwestern part of Hillsborough County and in southern Florida penetrate locally as much as 250 feet of limestone that may be assigned to the Tampa.

The Tampa formation consists essentially of limestone that ranges in color from white to brown. In general the limestone is harder, more compact, and less porous than the 0cala. The texture and hardness are variable, however, and some parts of it consist of loose masses of fossil organisms and other parts are chalky, dense, compact, silicified,

28 Dall, W. H., and Harris, G. D., Correlation papers - Neocene: U. S. Geol. Survey Bull. 84, p. Il7, 1892 .

29 Cooke, C. W., and Mossom, Stuart, op. cit., p. 79.

30 Idem.

31. Matson, G. C., and Clapp, F. G., Florida Geol. Survey 2d Ann. Rept., p. 87,1909 .

$45152 \mathrm{O}-36-2$ 
and cherty. Unlike the Ocala, the Tampa limestone is bedded. (See p1. 9, A.) In some localities the circulation of ground water through the limestone has formed cavities and more or less vertical cylindrical holes or natural wells simflar to those developed in the Ocala limestone. (See pl. 7, A.) The formation is overlain by the Hawthorn formation and is underlain by the Ocala limestone.

The Tampa limestone is an important water-bearing formation of the peninsula, chiefly in the western and southwestern parts, as in Hillsborough and Pasco Counties. In parts of the formation water occurs in caverns and cavities and along joints and bedding planes. Some of the limestone permits free percolation of water through it, but the dense cherty and silicified limestone is relatively impervious. The formation contains water under artesian pressure, confined by relatively impervious material within the formation and the overlying rocks. Generally water can be obtained throughout the formation, but in the southern part of the peninsula some of the limestone yields little or no water. In Hillsborough, Pinellas, and Pasco Counties the formation yields large quantities of water to wells and is the source of water for domestic and public supplies, including the supply for the city of st. Petersburg. It is also the source of some of the large springs, such as sulphur Spring, near Tampa.

Fresh water enters the formation in areas where it is exposed at or near the surface.

\section{Hawthorn formation}

In western Florida the Alum Bluff group comprises the Chipola formation, the Oak Grove sand, and the Shoal River formation. In the peninsula, however, it is represented only by the Hawthorm formation, which is considered to be contemporaneous with the Chipola or lower formation of the group as developed in westerm Florida.

The Hawthorm formation was named by $\mathrm{Dall} 32$ in 1892 after the town of Hawthorm. As now defined, "the Hawthorn formation includes the original Hawthorm 'beds' of Dall, but excludes the Cassidulus-bearing limestone and chert, which Matson and clapp placed in the Hawthorm formation but which is known to be Tampa. With it are tentatively in-

32 Dall, W. H., and Harris G. D., Correlation papers - Neocene: U. S. Geol. Survey Búll. 84, pp. 107-1il, 1892 .

33 Cooke, C. W., and Mossom, Stuart, op. cit., p. 115. 


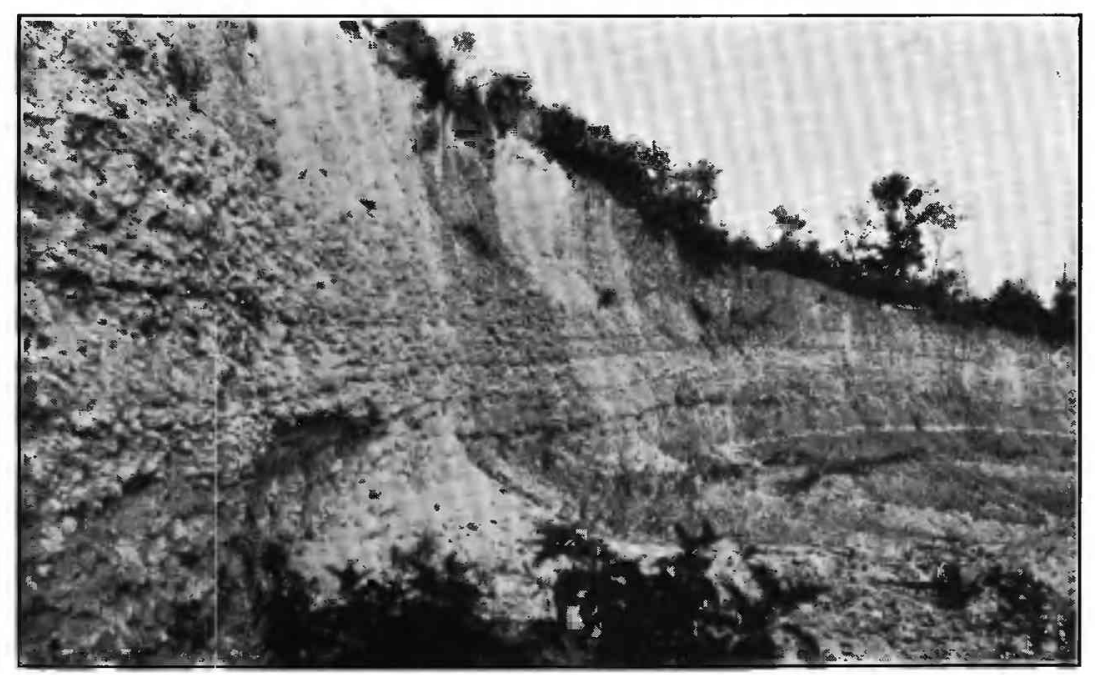

A. TAMPA LIMESTONE SHOWING BEDDING IN PORTLAND-CEMENT QUARRY ABOUT 11 MILES WEST OF BROOKSVILLE, HERNANDO GOUNTY.

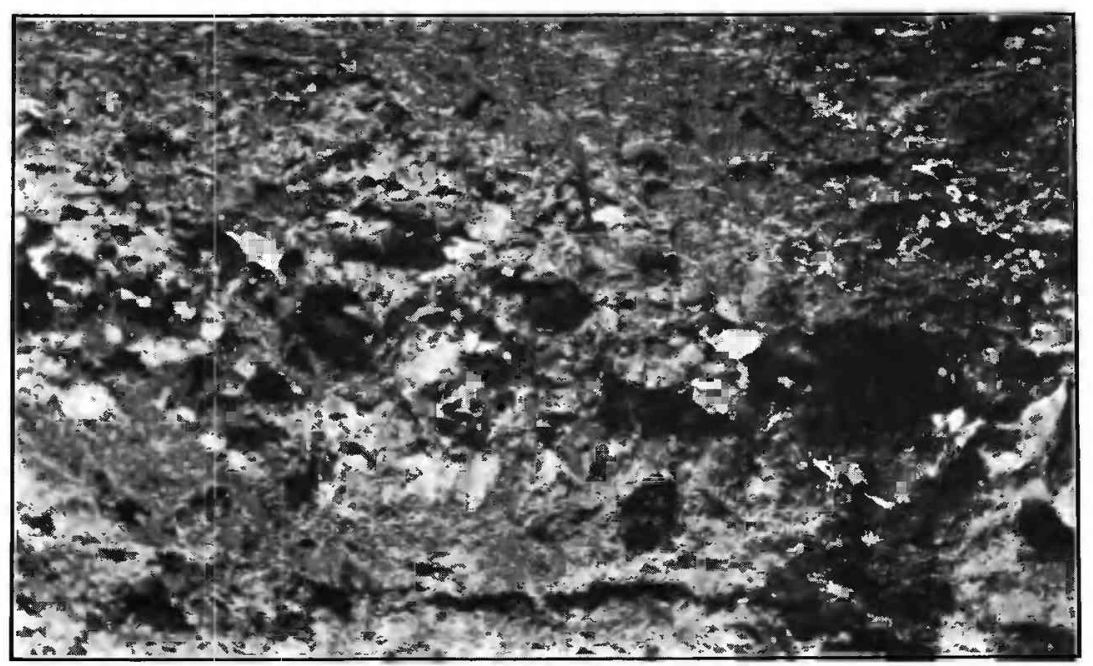

B. TAMPA LIMESTONE SHOWING WEATHERED LIMESTONE AND POCKETS OF CLAY IN PORTLAND-CEMENT QUARRY ABOUT 11 MILES WEST OF BROOKSVILLE, HERNANDO COUNTY. 
cluded Dall's 'Jacksonville Iimestone' 34 and 'Manatee Rlver marl, 35

which it has been impracticable to map separately, although their faunas seem to be younger than those of the typical Hawthorn. Dall's 'Sopchoppy Iimestone, ${ }^{36}$ of Chipola age, is also placed in the Hawthorn formation." As mapped by Cooke and Mossom,
37
near the surface in a large area that is in part adjacent to the outcrop of the Ocala and Tampa 1imestones and that extends from the northerm part of the peninsula to De Soto and Sarasota Counties, in the southerm part. It is one of the most extensive formations of Florida and is present throughout the peninsula except where it has been removed by erosion and the 0cala or Tampa limestones are present at or near the surface.

Records of wells in the peninsula indicate that the maximum thickness of the Hawthom formation is about 500 feet in the northeastern and southern parts of the peninsula. The formation consists essentially of several hundred feet of interbedded clay, sand, limestone, and sandy phosphatic IImestone and mar1. Some parts of the formation contain fuller's earth. According to Cooke and Mossom, the largest known exposure is at Devil's Mill Hopper, a sink about 6 miles northwest of Gainesville, in Alachua County, that cuts through at least 115 feet of Hawthorm beds to the Ocala IImestone, which doubtless lies not far below water level in the sink. The section at this place, as described and measured by Cooke, is as follows:

Section of Hawthorn formation at Devil's Mill Hopper

10. Covered; debris of calcareous sandstone................. Feet

9. Gray or cream-colored calcareous sandstone or sandy limestone containing round phosphatic grains, poorly preserved mollusks and echinolds; lower part more sandy and paler than upper; this bed has slumped several feet...... 15

8. Concealed; partiy encrusted with travertine.............. 27

7. Green sandy clay; upper part encrusted with travertine 1 inch to more than 4 inches thick and enclosing land

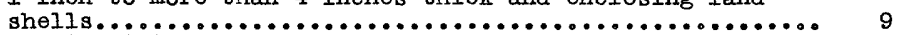

6. Hard silicified green clay or fulier's earth............ 5

5. Greenish-gray sand and fuller's earth ..................... 15

4. Covered........................................ 7

3. Hard cream-colored or yeliow phosphatic fossiliferous imestone at base, passing upward into sandy phosphatic limestone; probabiy a fallen block of bed $9 . . . \ldots . . . . . . .$.

34 Dall, W. H., and Harris, G. D., op. clt., pp. 124-125.

35 Idem, pp. 125-126.

36 Idem, pp. 119-120.

37 Cooke, C. W., and Mossom, stuart, op. c1t., p. 116, pl. 2.

38 Idem, p. 116 .

39 Idem, p. 129. 
Section of Hawthorn formation at Devil's Mill Hopper - Cont'd.

2. Soft calcareous sand with brown phosphatic pebbles and

Feet

molds of fossils; seen below waterfall on west side........ 2

1. White calcareous sandstone with phosphatic nodules; to

water level................................... 5

The Hawthorn formation overlies the Tampa limestone or, at many places in the peninsula, as in the eastern and northeastern parts, where the Tampa is absent, it lies directly and unconformably upon the 0cala limestone. It is overlain by the Choctawhatchee and younger formations. The Hawthorn includes permeable water-bearing beds of sand, limestone, and marl, above and below which are less permeable beds. In some localities the water-bearing beds contain solution channels that yield water to wells and springs. In general the lower part of the formation yields the most water, but usually wells supplied by water from the Hawthorn have only moderate yields, and where large supplies are required the wells are drilled into the underlying Ilmestones. With proper development, however, large supplies of water can be obtained from the formation. Much of the water in the Hawthorn is under artesian pressure, and the pressure head in the lower part of the formation appears to be comparable with that in the underlying limestone.

Fresh water enters the formation where it is exposed at or near the surface and in areas where it is overlain by permeable material.

\section{Choctawhatchee formation}

The Choctawhatchee formation as described by Cooke ${ }^{40}$ consists of beds of greenish or gray sandy and clayey micaceous shell marl and brown clay. Shell marl referable to this formation was penetrated between depths of 65 and 100 feet in a well at Kissimmee, in 0sceola County. On the Caloosahatchee River in Lee County Cooke and Mossom ${ }^{41}$ mapped a small area as Choctawhatchee formation because the soft limestone that underlies it contains a fauna of that age.

Except in certain Iocal areas, such as Osceola County, the Choctawhatchee formation is not considered an important water-bearing formation in the peninsula because of its slight areal extent.

40 Cooke, C. W., and Mossom, Stuart, op. cit., pp. 138, 149.

41 Idem, p. 140, pl. 2 . 


\section{Pliocene, Pleistocene, and Recent rocks}

The formations of Pliocene, Pleistocene, and Recent age in the peninsula are listed in the table on page 122. The character and distribution or these formations are described by cooke. In general they are surficial deposits overlying the older formations. The greatest thickness of these sedimentary deposits is in the southern part of the peninsula. They supply water to many shallow wells for domestic use and also to some wells for use as public supplies, such as those for Mlami and other cities in the coastal areas and southern Florida, where the deeper waters are highly minerelized.

\section{ARTESIAN WATER}

\section{General conditions}

Part of the water absorbed by the soil or surficial rocks percolates downward until it reaches a level where the rocks or soll are saturated with ground water. This saturated zone constitutes the body of ground water that jields water to wells, and its upper surface is known as the water table. The water table is not, as its name suggests, an even surface, because in general it is gently undulating, being highest beneath the hills and sloping toward nearby streams, lakes, or the ocean. The rainfall is large and makes large contributions to the ground water, and the water table is generaliy near the surface. In much of the southerm part of the peninsula, where the topographic relief is small and surface drainage is relatively sluggish, the water table is only a few feet in depth. Under the higher land, as in Pasco and Hernando Counties, and elsewhere in the central and west-central part of the peninsula, where the relief is relatively large, the water table lies deeper.

In some areas water percolates downward, encounters relatively Impervious material, and is prevented from reaching the main body of ground water. The water table thus formed is above and in part independent of the main zone of saturation and is known as a "perched water table." Where the static water level of nonflowing artesian wells is slightly above the main water table, as in some parts of Florida, care must be exercised to avoid interpreting the artesian water as representing a perched water table or the normal water table.

42 Cooke, C. W., and Mossom, Stuart, op. c1t., pp. 150-227, pl. 2. 
Under water-table conditions -- that is, where the water is not under artesian pressure -- many small water supplies are obtained throughout the peninsula. In the coastal areas and the southerm part, where the artesian water is too highly mineralized to be considered desirable for consumption, large nonartesian water supplies have been and may be developed in the future.

Many of the small water supplies and most of the large supplies in the peninsula are obtained from artesian weter. Where permeable rock strata are confined by relatively impermeable overlying and underlying strata, the water in the permeable strata is generally under hydrostatic pressure, and a well penetrating these strata is an artesian well, even though the water may rise in the well onj.y a short distance above the permeable rocks. Water from the surface enters the permeable rocks in areas of relatively high altitude where the impermeable material is not present. From such intake or recharge areas the water after it reaches the permeable rocks gradually moves laterally under the confining beds, in response to pressure produced by the recharge.

The Ocala limestone, the Tampa limestone, and the Hawthorn formation are the chief artesian water-bearing formations of the peninsula. The Hawthorn formation also contains relatively impervious beds that prevent or retard upward percolation from water-bearing zones of lower parts of the Hawthorn and from the underlying Tampa and Ocala limestones. The Tampa and Ocala also contain relatively impervious rocks, such as chert and silicified limestone, that prevent or retard upward percolation from lower water-bearing zones, and therefore artesian water is present in these formations in some areas where they are at or near the surface and the Hawthorn formation is absent. Artesian water is present throughout the peninsula except in parts of the recharge areas. The large rock fold shown in plate 6 provides the principal structural conditions for artesian water, but the recharge areas and the direction of movement of the artesian water are in part independent of the structure. (Compare pl. 12 and pl. 6.)

\section{Areas of artesian flow}

The general areas in which the artesian water is under sufficient pressure to rise to the surface and produce flowing wells are represented in plate 10. They include three principal areas -- the Atlantic coast, southern Florida, and the Gulf coast. The map indicates the limits of 


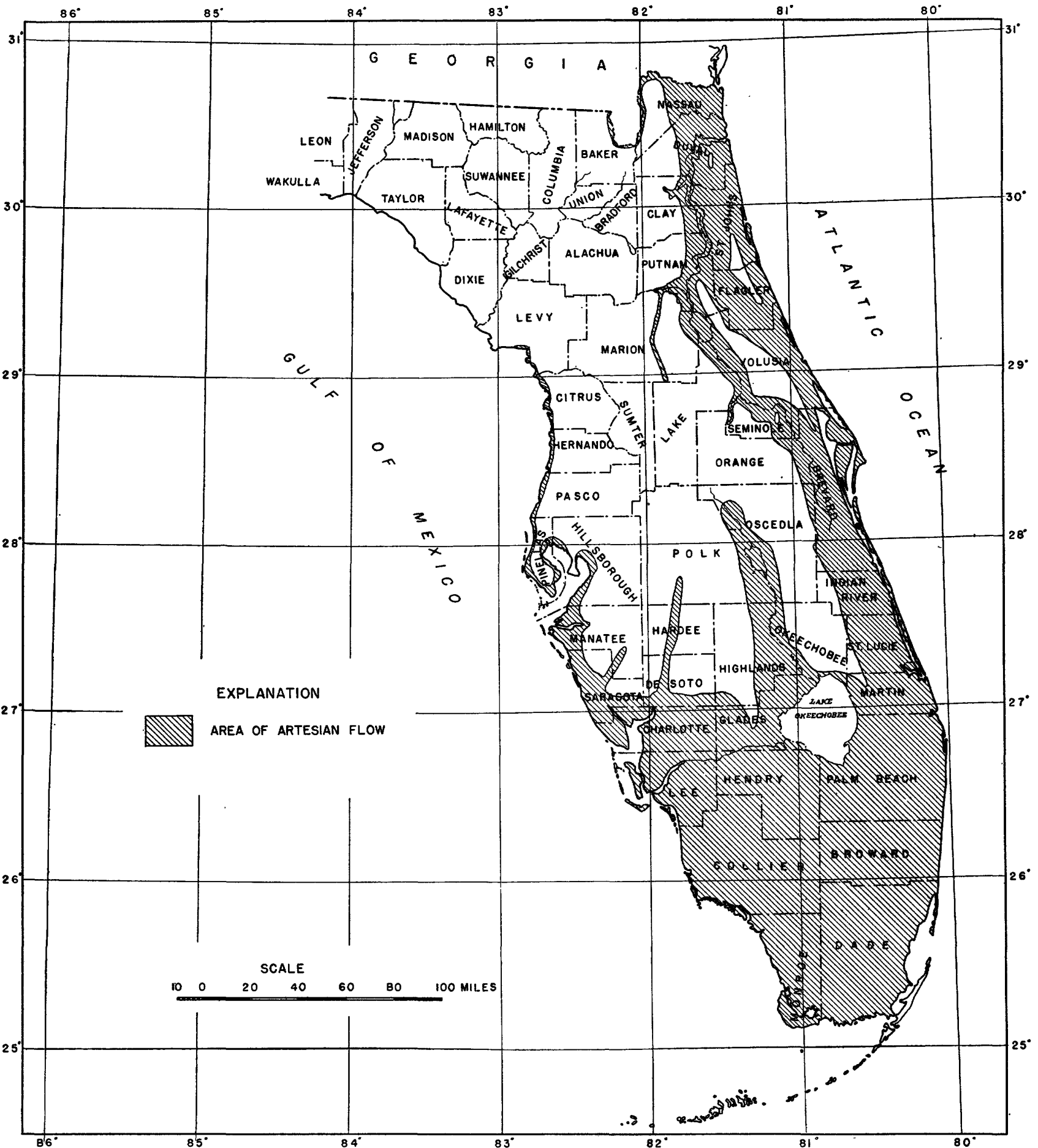

MAP OF FLORIDA PENINSULA REPRESENTING AREAS OF ARTESIAN_FLOW. 
the areas of flow only approximately, and more detalled work is necessary to determine the exact limits. Within the areas of flow there are relatively high districts in which wells will not flow; on the other hand, in parts of the peninsula shown as nonflowing areas flows may be obtained in some of the relatively low districts where the pressure head is relatively high.

Atlantic coast area.- The Atlantic coast area extends along the east coast of Florida from north to south. In the northern part it includes much of Nassau and Duval Counties and extends westward along the valley of the St. Marys River into Baker County. It includes the valleys of the St. Johns River and some of its tributaries, such as Black Creek and the Oklawaha and Wekiva Rivers. The area of flow along Black Creek and its tributaries extends into western Clay County. The area of flow along the Oklawaha River extends into the east-central part of Marion County. At the headwaters of the Oklawaha River, on the borders of some of the large lakes in Lake County, the artesian water in wells is near the surface of the ground. Flowing wells are obtained in the lowland bordering the southeast, south, and west sides of Lake Apopka, but on the north and northeast sides of the lake the pressure head is somewhat less and there are no flowing wells.

Southern Florida area.- The southern Florida area merges into the Atlantic coast and Gulf coast areas and covers all of the southerm part of the peninsula. It extends along the KIssimmee River Valley into northern Osceola County and along the Peace Creek Valley to the southerm part of Polk County. In the southern part of the peninsula there are a few relatively high areas, such as that west of Irmokalee, in northern Collier County, where wells will not flow. So far as known, wells on the Florida Keys are nonflowing, although the altitude of the surface is only a few feet above sea level.

Gulf coast area.- The Gulf coast area is chlefly a narrow strip along the Gulf of Mexico. It extends inland along the valley of the Miakka River in Sarasota and Manatee Counties and the larger valleys in Manatee and Hillsborough Counties. In Pasco, Hernando, and C1trus Counties flows may be expected only where the land surface is near sea level. 


\section{Artesian head}

The artesian head, sometimes called "pressure head" or merely "head", is the height with reference to some datum to which water will rise in a tightly cased well penetrating an artesian formation. The imaginary surface that represents the level to which water will rise in artesian wells is known as the "piezometric" or "pressure-indicating" surface. The piezometric surface may be represented by contours, or lines that pass through points where the head is at equal altitude above a given datum. (See pl. 12.) In order to determine the shape of the plezometric surface and the fluctuations of head, measurements were made of the water levels or pressure in observation wells at times when they were not discharging.

On wells with large pressure the head was determined by means of a pressure gage that indicated the height to which water would rise above the gage. On wells where the water would rise less than 5 feet above the surface the static level was determined by measuring the helght to which the water rose in a garden hose attached to the well. Where the water level stood below the top of the well casing the depth to water was measured with a steel tape. Continuous records of the fluctuations of water levels in a few wells were obtained by automatic recorders. (See p1. 11.)

The observed water levels and artesian head are shown in the table at the end of this report and are discussed below. The observed water levels range from a few feet above sea level in some areas near the coast to more than 100 feet above sea level in the central part of the peninsula.

\section{Increased head and flow with increased depth}

Differences in the head and flow at different depths may be expected in some parts of the peninsula. The head in the lower part of the Hawthorn formation and in the underlying formations differs from that in the middle and upper parts of the Hawthorm, as shown by wells in Duval County and many other parts of the peninsula. (See pages 165-189.) In general the head in the lower part of the Hawthorn formation is approximately the same as that in the underlying Tampa and Ocala, although most wells in the Hawthorn yield less water than those in the underlying formations. However, in certain areas increases in head and flow have been observed with increased depth. According to a record

43 Sellards, E. H. and Gunter, Herman, The artesian water supply of eastern and southern Florida: Florida Geol. Survey 5th Ann. Rept., pp. $146-147,1913$. 


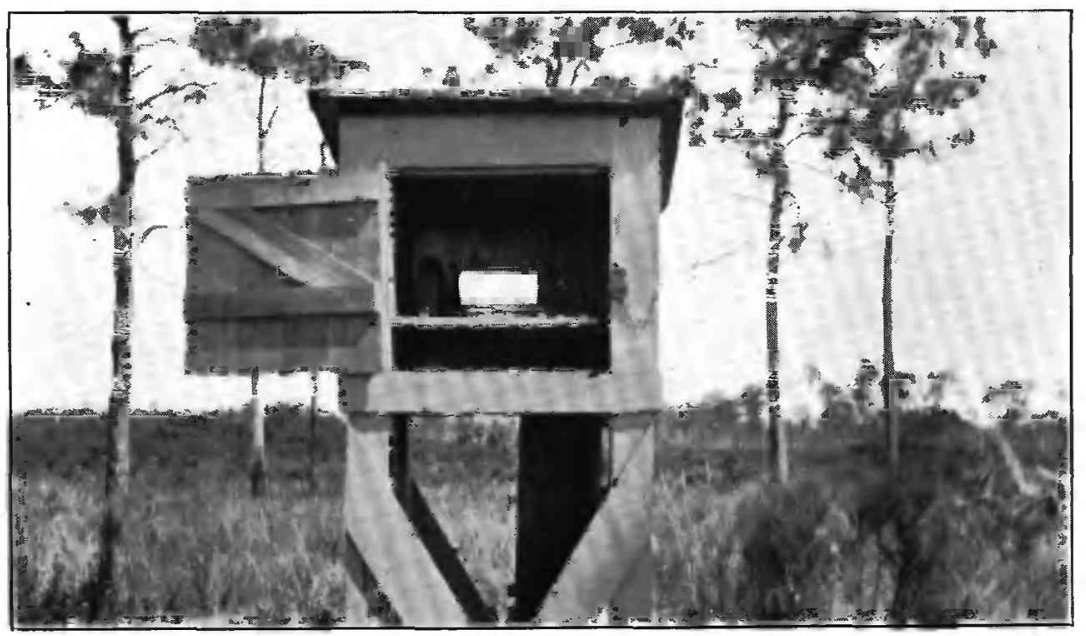

A. WATER-LEVEL RECORDER ON WELL 9, SARASOTA COUNTY.

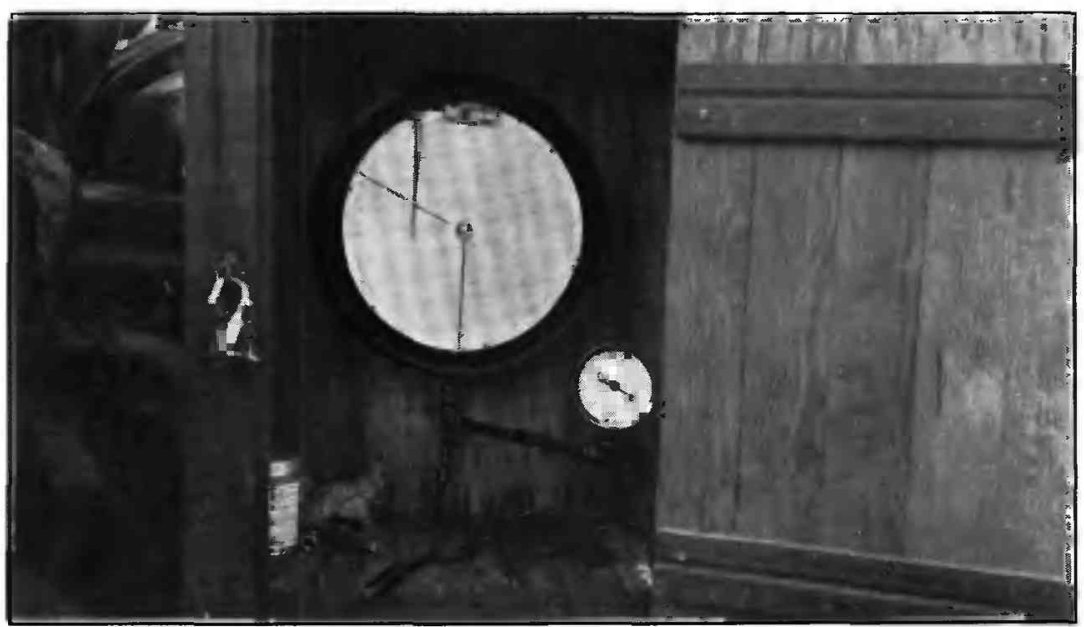

B. WATER-PRESSURE RECORDER ON WELL 18, DUVAL COUNTY. 


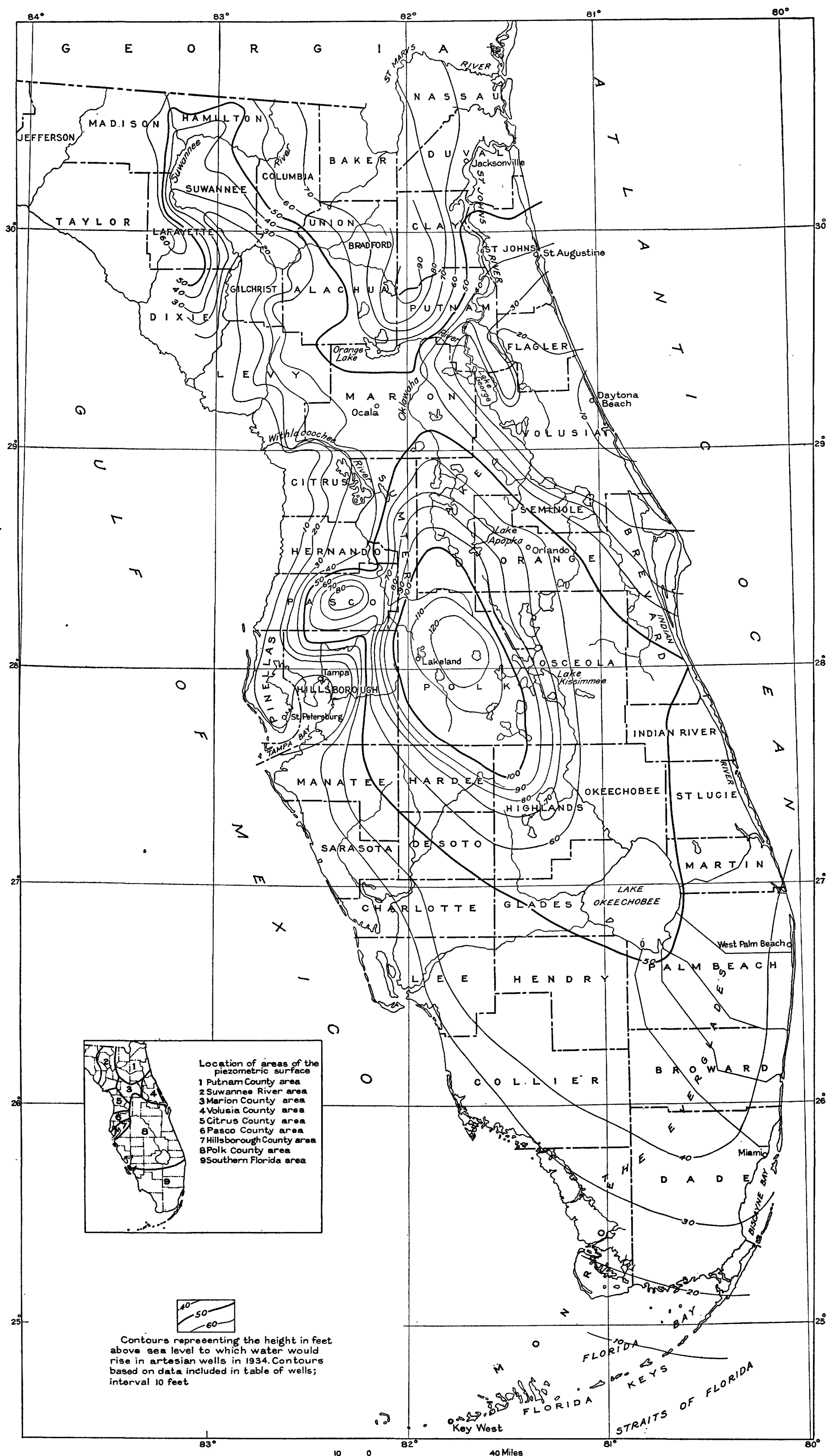

$10 \quad 40$ Miles 
of well 10 of the city water supply of Jacksonville, in Duval County, the artesian water had a pressure head of 27.72 feet with reference to the ground surface when the well reached a depth of 680 feet and a pressure head of 34.65 feet when it reached a depth of 900 feet. The flow was about 5 gallons a minute from a depth of 270 feet, 900 gallons a minute from a depth of 900 feet, and 1,500 to 2,000 gallons a minute from a depth of 980 feet. The well penetrated about 500 feet of the Hawthom formation and entered the 0cala limestone at a depth of about 510 feet.

An incomplete $\log ^{44}$ of the well at the Ponce de Leon Hotel, at St. Augustine (well 27, St. Johns County), indicates that the artesian water had a pressure head of 32 feet with reference to the surface of the ground when the well reached a depth of 170 feet, a head of 38 feet when the well reached a depth of 350 feet, and a head of 42 feet when the well reached a depth of 520 feet. The Ocala limestone was penetrated at a depth of about 170 feet. The pressure head of this well in 1930 (see pages 173, 187) was about 30 feet with reference to the surface of the ground. That pressure head appears to be about the average for wells penetrating the Ocala limestone in the vicinity of St. Augustine -- a fact which suggests that where wells penetrate water-bearing beds at several horizons with different artesian pressures there will be an equalization of pressure in the beds at different horizons in the vicinity of the wells, as discussed under "Leakage of wells", unless the wells are so cased that they will prevent such leakage.

A difference in pressure head at different depths is also reported in the Ocala limestone in Sumter County. See table of wells at end of report. However, in Volusia, Seminole, and Sarasota Counties and some other parts of the peninsula wells much deeper than the average have been constructed in an unsuccessful attempt to obtain larger pressure heads and yields. Several of the deeper wells penetrated beds yielding highly mineralized water.

\section{Fluctuations of artesian head}

Observations have indicated that the head of the artesian water is fluctuating almost constantly. In order that the character of the piezometric surface could be interpreted and the effect of recharge and discharge of water determined, it was necessary to ascertain so far as possible the causes and amounts of these fluctuations. They were found

44 Matson, G. C., and Sanford, Samuel, op. cit., p. 396. 
to range from less than a foot to several feet. Some of the observed causes of fluctuations are rainfall, barometric pressure, tides, rivers, drainage wells, and artesian flow or pumpage from wells.

Fluctuations caused by rainfall

In recharge areas, such as Marion County, the water levels in wells may rise as much as 10 feet within a period of a few weeks, and much of the rise may be attributed to rainfall that enters the water-bearing formations. The graphs based on intermittent measurements of water level in wells 40,41, and 42, Marion County (fig. 11) show examples of such fluctuations. Rainfall in Florida is often localized, and the record at Ocala represents only in a general way the rainfall in the intake areas of the wells. The effect of rainfall in the recharge area is transmitted to other parts of the formation, but this transmission is usually slow, requiring weeks or perhaps months, the time depending on the distance and the hydrologic conditions; moreover, with distance the magnitude of the effects decreases. In parts of the peninsula at some distance from recharge areas rainfall may indirectly cause fluctuations of water levels in wells. The hydrograph of well 9, Sarasota County, in an irrigation district, together with the record of rainfall show in figure 12, shows that there is a marked increase in head during some periods after rains. For example, in 1931 a considerable increase in head followed rains of 1.08 inches on February 17, 1.81 inches on March 2 , and 3.29 inches on April 15, with smaller amounts on the days immediately preceding and following. At certain other times, however, there has been considerable rainfall without such marked increase in the head. Generally when rain occurs in appreciable amounts auring the irrigation season many of the flowing wells are closed, and this reduction in withdrawal of artesian water is the principal cause of increased head.

Matson points out that rainfall may cause some increase in the head by the added welght of the rain water that may accumulate in the formation overlying the artesian formation. This weight may be transmitted to the underlying formation and may thereby cause an increase in artesian head. Increases of pressure after rains have been reported by owners of wells in Seminole County, but these wells are in irrigation districts, and the changes in head may be caused by the closing of the flowing wells, as described, above. Moreover, in Seminole County there may be local recharge of the artesian formations.

45 Matson, G. C., and Sanford, Samuel, op. cit., pp. 238-239. 


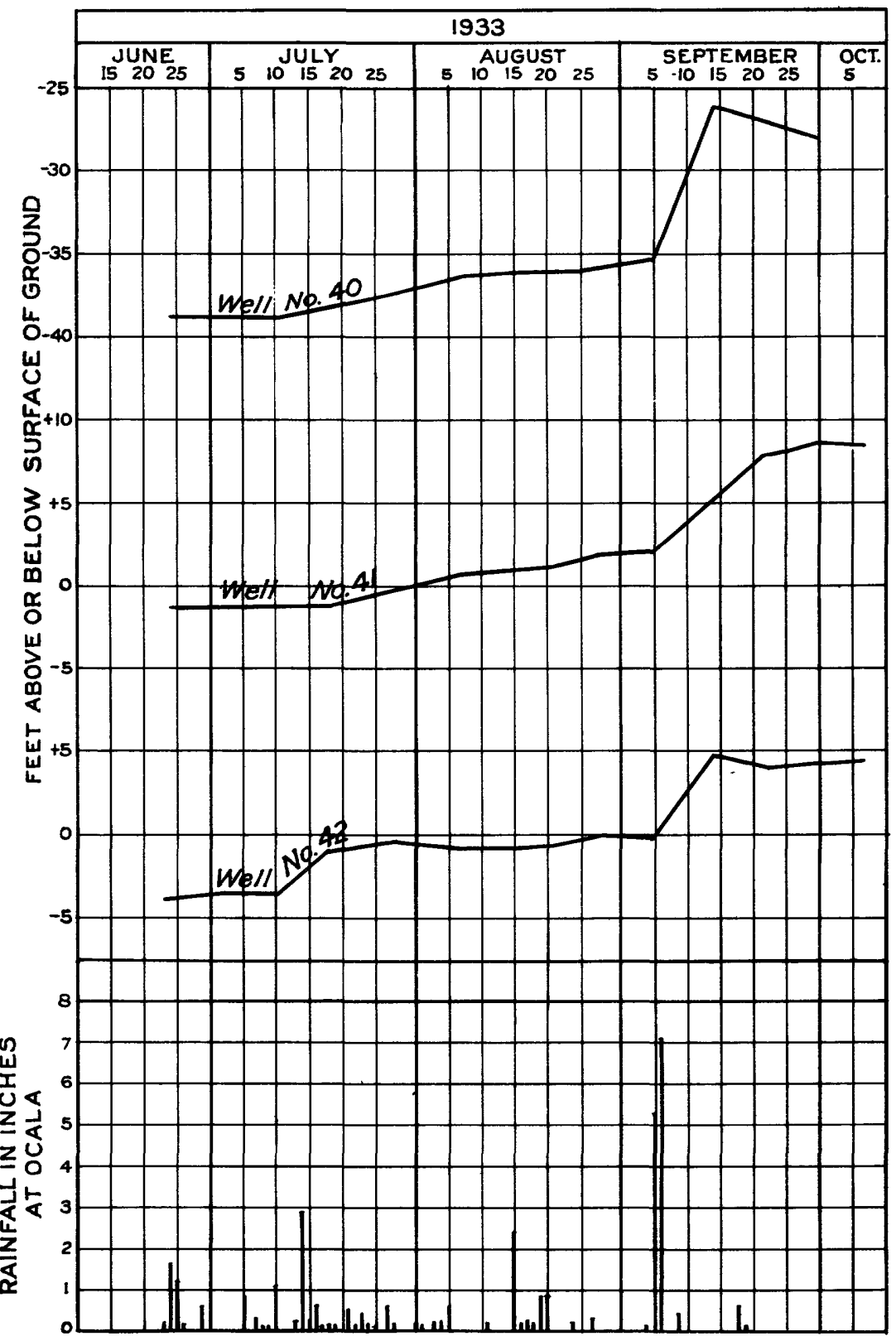

Figure 11.- Fluctuations of ground-water level and rainfall in Marion County, by days, June to October 1933. 


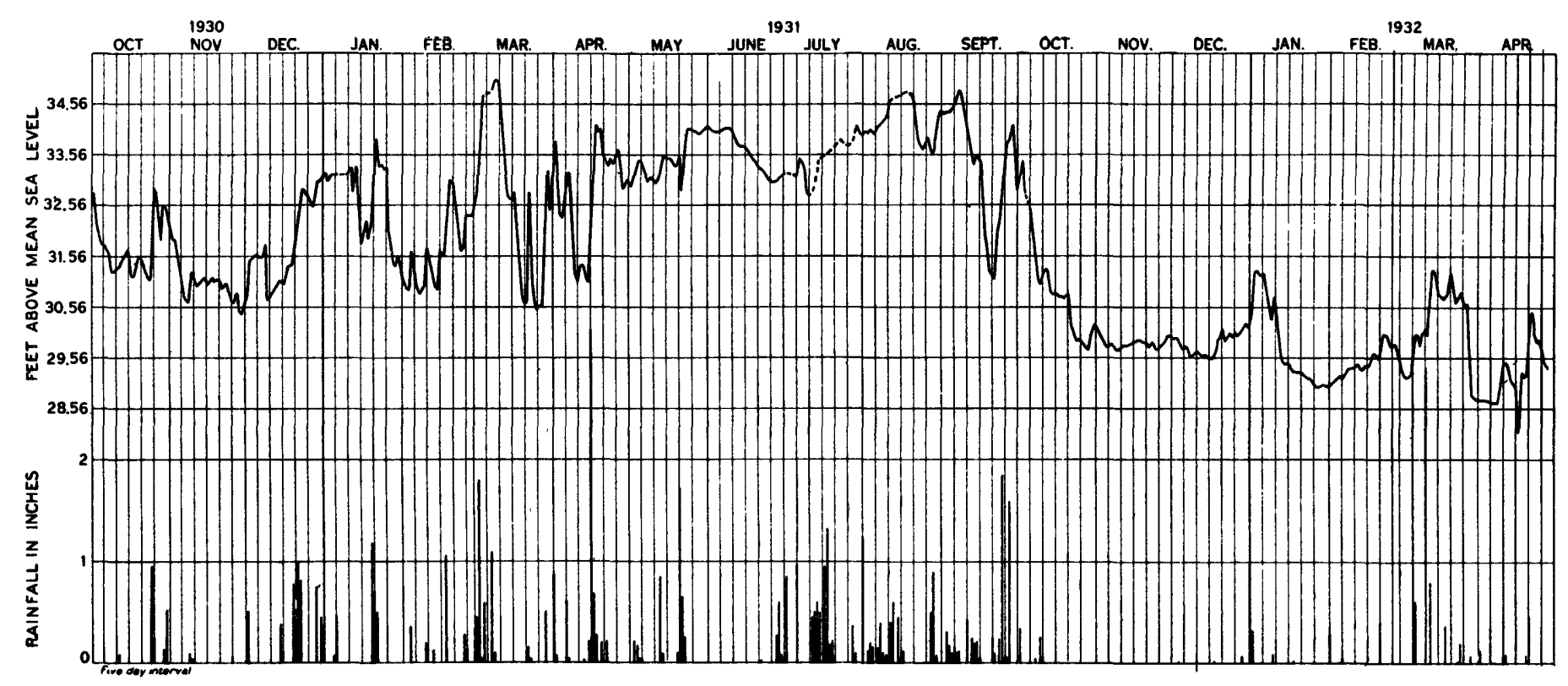


Fluctuations caused by changes in atmospheric pressure

Variations in atmospheric pressure probably tend to cause fluctuations in the head of water in all artesian wells, but these fluctuations may be masked by greater fluctuations due to other causes, chiefly variations in withdrawal of water. The fluctuations of the water level in well 9, Sarasota County, during a period when there was little discharge of water from artesian wells in that vicinity, is represented in figure 13. This diagram also shows the fluctuations in atmospheric pressure as recorded by a barograph in Sarasota. The barograph record, representing atmospheric pressure in inches of mercury, has been transformed to equivalent pressures in feet of water, and the graph inverted in order that it may be compared more readily with the graph representing the fluctuations in water level. As plotted, a downward trend of the barometric graph represents an increase in barometric pressure, and vice versa. The similarity of the two graphs is evident and is caused by changes in barometric pressure. The lack of similarity at some points may be attributed in part to differences in the sensitivity of the recording instruments and to the fact that the original barograph record is on a small scale, in which it is difficult to detect slight differences that would appear clearly in the graph made by the water-stage recorder. The two graphs in figure 13 show a semidiurnal cycle which is a characteristic of changes in barometric pressure. In addition to these small fluctuations more gradual changes appear on both graphs, which during a period of several days -- for example, between June 8 and 12 -- amount to as much as 0.5 foot. Such fluctuations of atmospheric pressure in cycles of a few days of stormy and fair weather, together with the semidiurnal cycles, reveal the close relation between fluctuations of the water level and changes in barometric pressure. The movement of water level is nearly equal in amount to the change in barometric pressure expressed in terms of feet of water pressure.

Barometric fluctuations of water levels in wells have been observed in many localities, and the explanation of this phenomenon has been discussed by Meinzer. 46

46 Meinzer, O. E., Outline of methods of estimating ground-water supplies: U. S. Geol. Water-Supply Paper 638, pp. 140-142, 1932. 


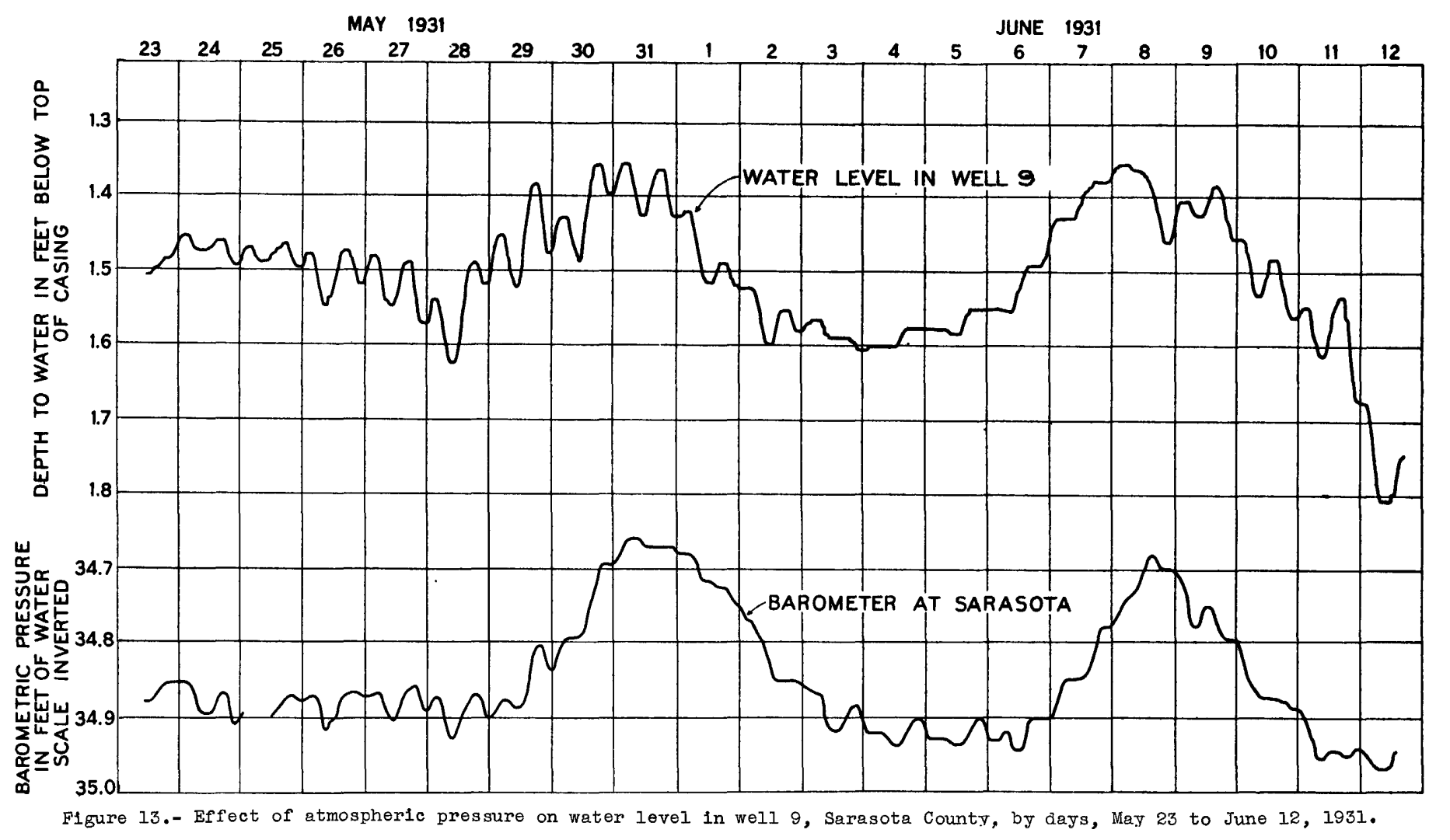

葆 
Fluctuations caused by ocean tides

According to the records of a continuous water-stage recorder, a few observations, and many reported measurements, the head and yield of artesian wells near the coast of the Florida peninsula are affected by ocean tides. The maximum fluctuation observed that can be definitely attributed to that influence amounts to about 1 foot in wells near the Gulf of Mexico and 2 feet in wells near the Atlantic Ocean. The farthest point inland at which tidal fluctuations in head were definitely observed was about $0.2 \mathrm{mile}$ from the nearest tidal water body.

The continuous records indicate that there is a semidiurnal variation of 1 to 2 feet in the artesian head on the Atlantic coast at Jacksonville Beach,in Duval County. The variation is undoubtedly caused by the tides in the ocean. The maximum pressure corresponds to the high tide, and the low pressure to the low tide.

Tidal fluctuations in wells may be attributed to one of two causes -(1) the transfer of water between the ocean and the ground water through the water-bearing formations; (2) the alternate compression and expansion of the water-bearing formations by the added weight of water transmitted in the vicinity at high tide and the removal of the weight at low tide. The conditions in much of the coastal area of the peninsula, so far as they affect the occurrence of water in the artesian formations, are reported to be somewhat comparable to conditions in the vicinity of Atlantic City, N. J., where it has been demonstrated by Thompson ${ }^{47}$ that fluctuations in the head of water in wells drawing from a bed at a depth of 800 feet are due to the alternate tidal loading and unloading in the immediate vicinity and not to any pressure change transmitted from the suboceanic outcrop of the bed.

\section{Fluctuations caused by rivers}

In the northwestern part of the peninsula, along the Suwannee River and the lower course of the Santa Fe River, and in the west-central part, along the lower course of the Withlacoochee River, any change in the stage of the rivers affects the ground-water level. In parts of their courses these rivers flow on the water-bearing formations.

47 Thompson, D. G., Ground-water supplies of the Atlantic City region: New Jersey Dept. Cons. and Devel. Bull. 30, pp. 27-30, 57, 113, 1928, and unpublished data. 
The ground-water level near the streams is generally about the same as the water level in the rivers, but during flood stages the rivers lose water to the formations and thereby cause the ground-water levels in adjacent areas to rise. Such fluctuations have been noted in a well at High Springs, in Alachua County; in a well at Branford, in Suwannee County; and in Falmouth Spring, near Falmouth, in Suwannee County.

Fluctuations caused by artificial drainage into wells

In areas where there is artificial drainage of surface water into wells the water levels in the other wells may rise several feet during and after periods of heavy rainfall. The record of a continuous water-level recorder on a well near 0coee, in Orange County, shows the marked influence of drainage wells in that vicinity. Although no water entered the mouth of the recorder well, there was a rise in water level after each rain, and the maximum rise was about 6 feet, during a 3-day period. At Orlando, in 0range County, where there are numerous drainage wells, water levels in wells rise as much as 10 feet after periods of large rainfall. Figure I4 is a graph representing intermittent measurements of water levels showing fluctuations over a period of several years in a typical drainage well in orlando.

Fluctuations caused by natural artesian flow or pumpage

In some of the irrigation districts, as in Sarasota, Manater, and Seminole Counties, and some of the cities, such as Jacksonville, large fluctuations of water level are caused by variations in the draft from wells. Figure 15 shows the movement of the water level in well 9 in Sarasota county and illustrates typical fluctuations at certain times of the year when artesian water is being used for irrigation. During such times the head in the well fluctuates considerably because of the opening and closing of wells on farms within a radius of about 2 miles. In 1 day the water moved as much as $I$ foot, and in a period of 3 weeks the maximum range in head was about 4 feet. Figure 16 shows the fluctuations in this well from October 1930 to March 1935.

A fluctuation of about 18 feet has been recorded on a well at the Water Works Park in Jacksonville (well 18, Duval County). That fluctuation is undoubtedly caused by changes in the rate of draft from the wells that furnish the public supply and possibly from nearby industrial wells. Well 9 in Sarasota County, mentioned above, is some distance from a discharging well. Obviously the fluctuations may be much larger in wells from which the water is being withdrawn. 

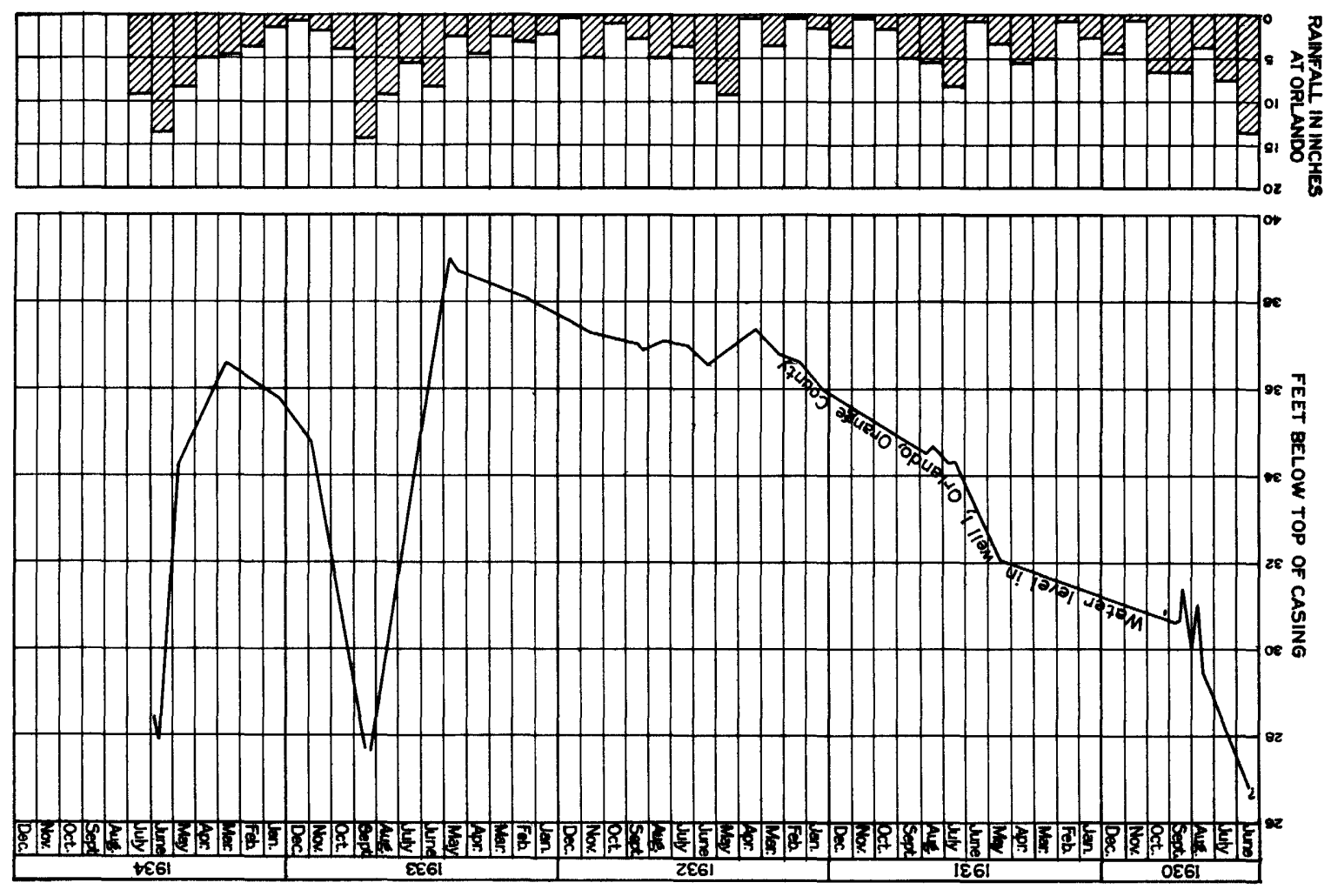

F1gure 14.- Water level in well 1, Orange County, and rainfall, by months, June 1930 to June 1934. 


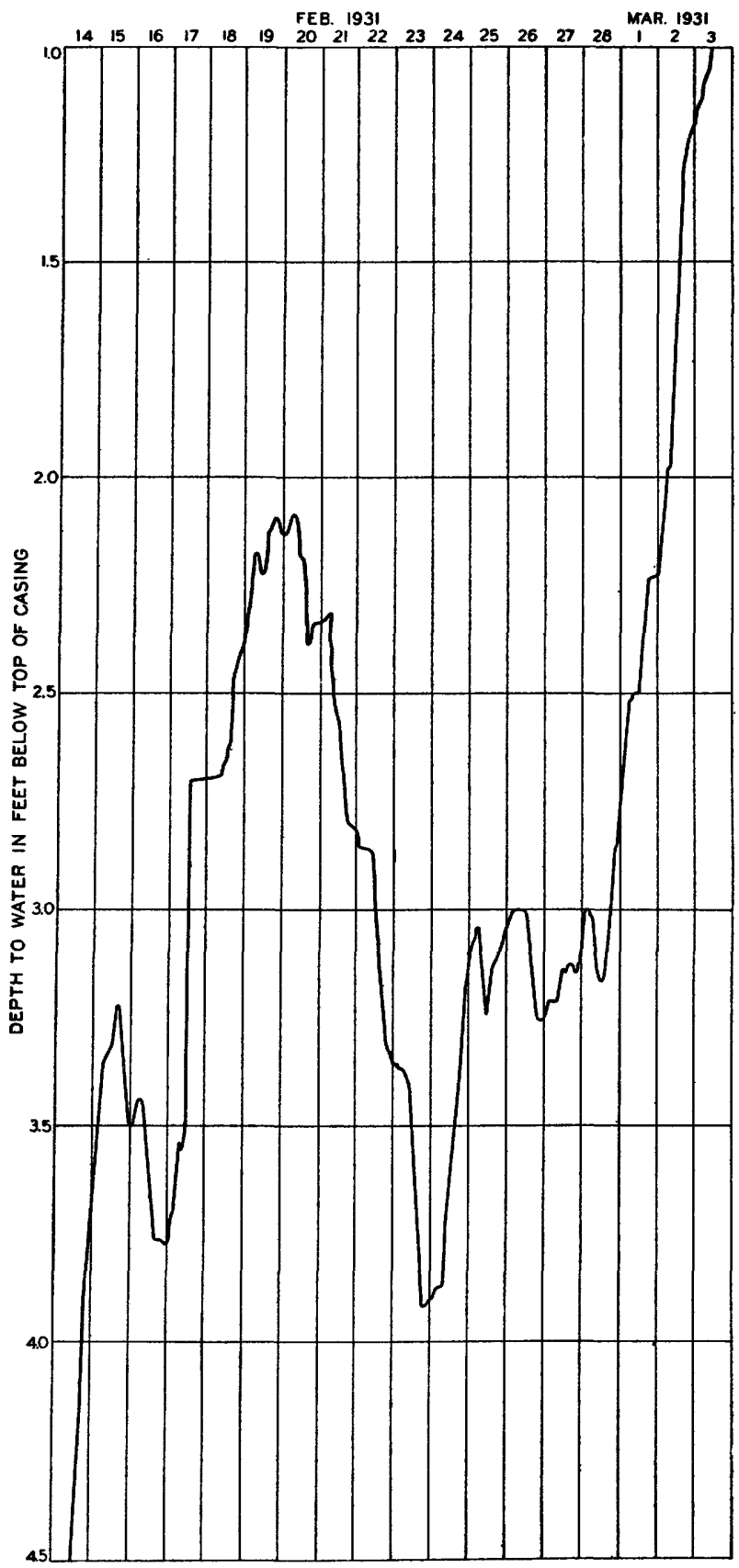

Figure 15.- Water level in well 9, Sarasota County, by days, February 14 to March 3, 1931, showing influence of draft from other wells. 
Permanent loss in artesian head

Details of the history of the artesian head in the peninsula are not complete, but general and incomplete data indicate a permanent loss of head in some localities where mach artesian water is being used. The loss of head is a normal process that invariably accompanies the withdrawal of artesian water in large amounts.

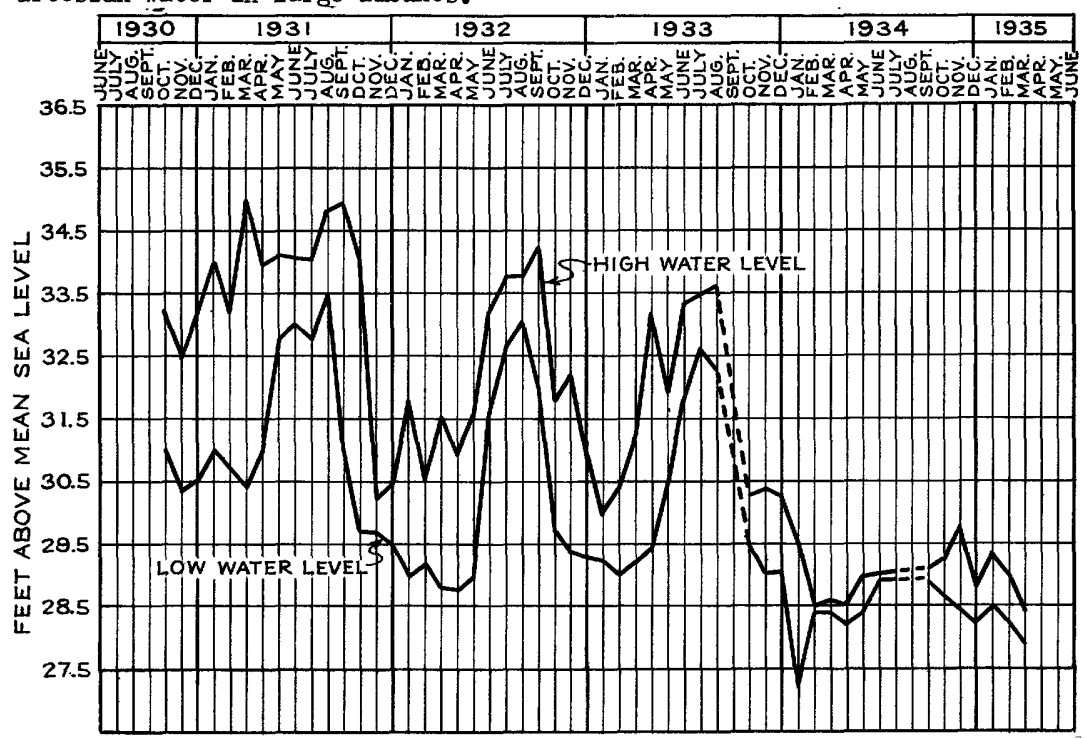

Figure 16.- Lowest and highest water level in well 9, Sarasota County, by months, October 1930 to March 1935 .

The initial head in a 10-inch well 980 feet deep, drilled in Jacksonville in 1903 by R. M. Ellis, was 58 feet above the surface, or about 68 feet above sea level. ${ }^{48}$ Well data compiled in 1905 by Darton show that several of the representative wells of Jacksonville had heads of about 62 feet above the surface. At the present time the minimum head noted in this vicinity is about 30 feet above sea level, and the maximum is about 54 feet above sea level. In other areas of large draft where many wells are in use, as in Volusia, Seminole, Manatee, and Sarasota Counties, a comparison of recent measurements with reported records indicate a loss of head of 5 to 10 feet. However, in mich of the peninsula the draft of artesian water is widely distributed, and no considerable loss of head has yet been caused by withdrawal of the water.

48 Fuller, M. Io, and Sanford, Samuel, Record of deep-well drilling for 1905: U. S. Geol.' Survey Bull. 298, p. 47, 1906.

49 Darton, N. H., Preliminary list of deep borings in the United States: U. S. Geol. Survey Water-Supply Paper 149, p. 25, 1905. 


\section{Piezometric surface}

The piezometric surface, or pressure-indicating surface, shown by means of contour lines on plate 12, represents the height to which artesian water would rise above mean sea level in 1934 in tightly cased wells that yield water from the Ocala or the Tampa limestone or in some localities from the lower part of the Hawthorn formation. Records of the wells are given on pages 165 to 189. The water in the Ocala and Tampa Iimestones and the lower part of the Hawthorn formation is under approximately the same pressure, but the water in the middle and upper parts of the Hawthorn formation has pressure heads that may be higher or lower than those in the underlying rock.

The high areas of the piezometric surface in general indicate recharge, and the low areas indicate discharge. However, recharge may occur in some of the areas of relatively low pressure. The water moves from the higher to the lower areas of the piezometric surface and at right angles to the contour lines representing that surface.

The map of the piezometric surface is based chiefly on observations made in 1934 and shown in the tables at the back of the report. Some of the well records obtained in the north-central part of the peninsula by the United States Engineer office at Jacksonville are also included. The altitudes of the measuring points of some of the wells in Sarasota, Orange, and Seminole Counties and of the wells measured by the United States Engineer office were determined by instrumental leveling and are recorded in the table on pages 165 to 189 to the nearest tenth of a foot. The altitudes of the measuring points of the other wells were determined by means of surveying aneroids and are shown in the table only to the nearest foot. The limits of error were sufficiently small to permit a fairly correct representation of the major features of the piezometric surface.

Obviously because of fluctuations of the pressure head the position of the piezometric surface is changing almost constantly, and a representation of it at any one time shows only approximately the conditions at any other time. Nevertheless, the map represents the major features, wich do not change except in details from time to time.

In the central and northern parts of the peninsula (figs. 17, 18) the piezometric surface is 90 feet or more above sea level, but in the intervening saddle it is only about 40 to 50 feet above sea level. It slopes toward the Gulf coast to an altitude of about 2 to 10 feet and toward the Atlantic coast to an altitude of 10 to 50 feet. In the southerm 
part of the peninsula it is relatively flat and ranges from only a few feet to about 50 feet above sea level.

For convenience in describing the piezometric surface the peninsula is divided into nine areas, each of which includes one or more of the major features. The general location of these areas is shown on the inset in plate 12.
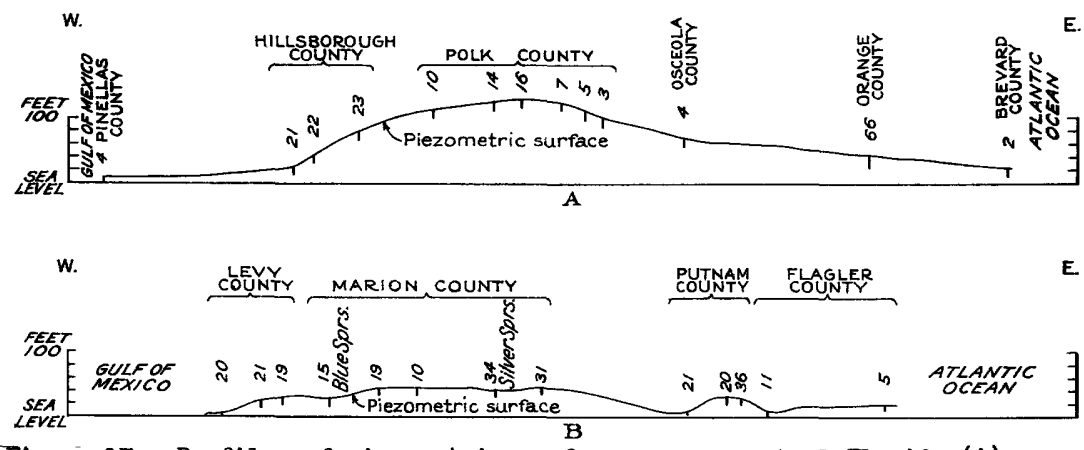

Flgure 17.- Profiles of piezometric surface across central Florida (A) and north-central Florida (B). Numbers are well numbers.

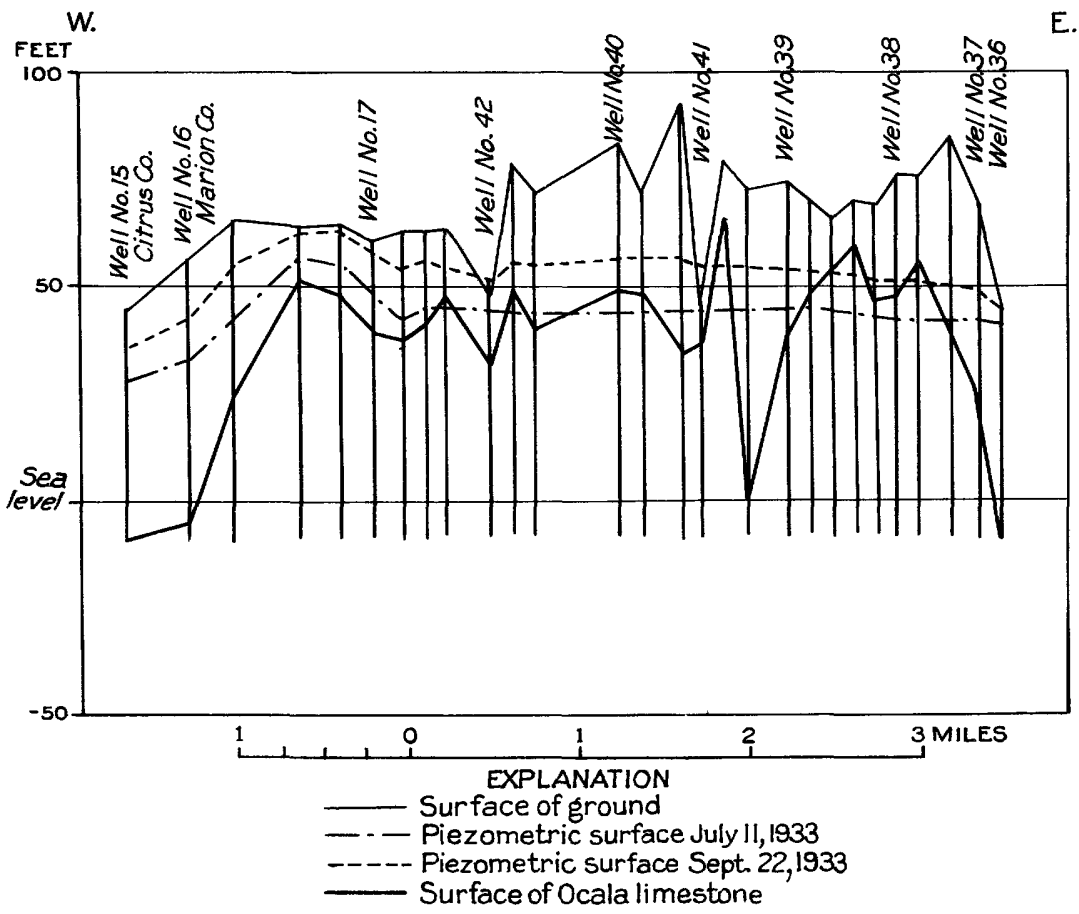

Figure 18.- Profile of piezometric surface in the southern part of Marion County. 


\section{Polk County area}

One of the most conspicuous features of the piezometric surface is in the central part of the peninsula, in Polk and adjacent counties, where this surface has the shape of an elongated dome, a large part of which is 90 to 120 feet above sea level. This dome extends northward into Marion County to an altitude of about 50 feet. It extends southward into the southern part of the peninsula, where it merges about 50 feet above sea level into a relatively flat part of the piezometric surface. The total north-south extent is about $150 \mathrm{miles}$. It extends to the Atlantic coast on the east, where it has an altitude of about 40 to 50 feet. On the west it extends to Tampa Bay, where it has an altitude of 10 to 20 feet. On the northwest it merges into a relatively small saddle and dome-shaped feature in Pasco County. The total east-west extent is about 120 miles. The piezometric surface in this area indicates local recharge of the water-bearing formations, largely in Polk County. It appears that some recharge may take place in the lake region in the northwesterm part of Highlands County and the south-central part of Lake County and in the lake region of Orange County. The recharge through drainage wells at Orlando and in adjacent parts of Orange County is evident.

The Ocala and Tampa limestones are overlain in part of the Polk County recharge area by relatively impervious members of the Hawthorm formation. However, well records indicate that in parts of the area the Hawthorn formation is relatively thin or absent and pervious sands rest directly on the water-bearing formations. For example, the $\log$ of a well at Davenport (well 5, Polk County) indicates the presence of unconsolidated quartz sand to a depth of lilo feet. Phosphatic marl, probably representing the Hawthorn formation, occurs in the interval between 110 and 120 feet, below which is soft limestone of the Ocala. Under such conditions local recharge of the ocala limestone may readily occur. Also within the area there are numerous lakes that probably occupy old sink holes now filled with sands that permit downard percolation of water. There are few surface streams in this area, and the rainfall drains into the numerous lakes and depressions, providing a large source of water for recharge.

Lateral movement of ground water takes place in all directions from the central part of the Polk County recharge area. It supplies the fresh artesian water of the Ocala, Tampa, and Hawthorn formations in the southern part of the peninsula and contributes artesian water to other adjacent areas. 


\section{Pasco County area}

In a relatively small area in northeastern Pasco County, west of the Polk County area, the piezometric surface is about 80 feet or more above sea level. It slopes northward into Hernando Courty to an altitude of about 30 to 40 feet and westward to the Gulf of Mexico and southward to Tampa Bay to an altitude of about 10 feet. On the east it is bordered by a small saddle about 60 to 70 feet above sea level. In most of the area the Tampa limestone is at or near the surface and permits ground-water recharge. The Hawthom formation with relatively impervious material overlies the Tampa limestone in northeastern Pasco County, where the piezometric surface is 80 feet or more above sea level. However, within that area there are sink holes and lakes occupying sink holes through which recharge may take place, accounting in part for the high water levels. The geology, topography, and ground-water conditions in some respects are comparable to those of the Polk County area.

Lateral movement of the ground water takes place in all directions from the central part of the recharge area. This recharge area furnishes fresh ground water in the Tampa and Ocala formations in most of Pasco County, parts of Hernando and Pinellas Counties, and the northwestern part of Hillsborough County.

The water in well 11, Pasco County, in sec. 16, T. 25 S., R. 21 E., stands 190 feet above sea level and 120 feet above the piezometric surface in that locality. This well, however, taps ground water in the Hawthorn formation, and the water level is not part of the piezometric surface.

\section{Putnam County area}

In the northwesterm part of Putnam County and the adjacent parts of Clay, Bradford, Baker, and Alachua Counties the piezometric surface is about 50 to 90 feet above sea level. On the north, in Bradford and clay Counties, it forms a ridge 70 to 80 feet above sea level and extends at that altitude into Georgia. On the east it slopes to the Atlantic Ocean to an altitude of about 30 to 50 feet. On the south it merges into a broad saddle about 40 to 50 feet above sea level in Marion County. On the west it forms a broad area in Alachua County about 40 to 50 feet above sea level. It also extends to the Suwannee River Valley, where it ranges from a few feet to about 50 feet above sea level. 
The artesian formations are not exposed where the piezometric surface has an altitude of 70 to 90 feet, but typical sink-hole topography affords conditions favorable for recharge. In the southern and western parts of the area recharge takes place through sink holes or directly into the ocala and Tampa Iimestones where they are present at or near the surface.

In Baker County, in the northerm part of the area, although the piezometric surface of the water in the Ocala limestone may be 70 feet or more above sea level, no recharge of the Ocala takes place locally because it is overlain by relatively impervious beds of the Hawthorn formation. However, water is supplied through a recharge area in Georgia.

Well I in Baker County is the only well reported in that county that probably penetrates the Ocala Iimestone. The other wells reported terminate in the middle and upper parts of the Hawthorn formation, and in parts of this area the water levels in such wells will rise higher than water levels in wells penetrating the Ocala. In parts of Duval and Nassau Countles, however, the pressure head of the artesian water of the Hawthorn formation is less than that of the 0cala.

In Jacksonville and vicinity, in Duval County, the piezometric surface has the shape of an inverted cone about 6 miles in diameter and 30 feet deep. The apex of the cone is in the vicinity of Water Works Park in Jacksonville and is about 30 feet above sea level. This was described in a manuscript prepared in 1927 by Malcolm Plrnie, consulting engineer, who made a careful study of artesian conditions for the clty of Jacksonvilie. This cone of depression doubtless is caused in part by the draft from wells in that vicinity, estimated to be about 20 million gallons a day.

At Green Cove Springs and vicinity, in Clay County, a small local depression carries the piezometric surface to about 30 to 40 feet above sea level. The draft from wells in this area is relatively small and appears to be insufficient to cause the depression, which may be due in part to subsurface leakage from wells. The flow of Green Cove Springs doubtless affects the head of water in the Hawthorn formation in the vicinity of the springs, but it probably does not affect the head in the underlying Ocala limestone.

In the southern part of the Putnam County area the water in the Ocala and Tampa limestones moves laterally from the recharge area into Putnam, Alachua, Marion, Clay, and Bradford Counties. In the northerm part of the area some of the water moves to the east and southeast, into Nassau and Duval Counties, and some of it moves to the west, toward the Suwannee River. 


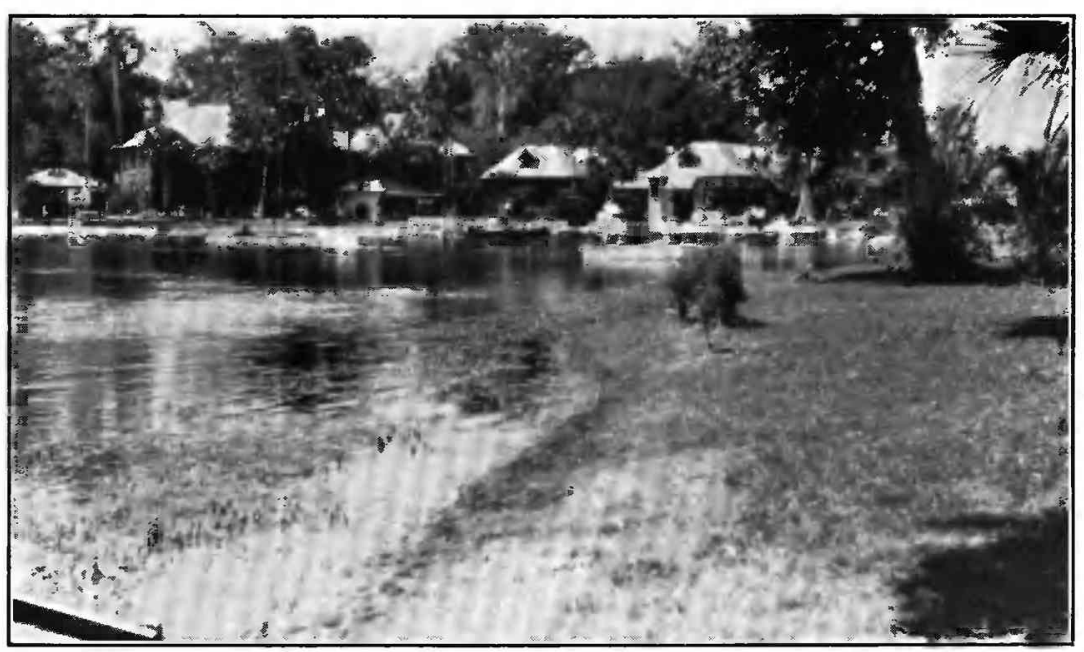

A. SILVER SPRINGS, MARION COUNTY, LOOKING TOWARD HEAD OF SPRINGS.

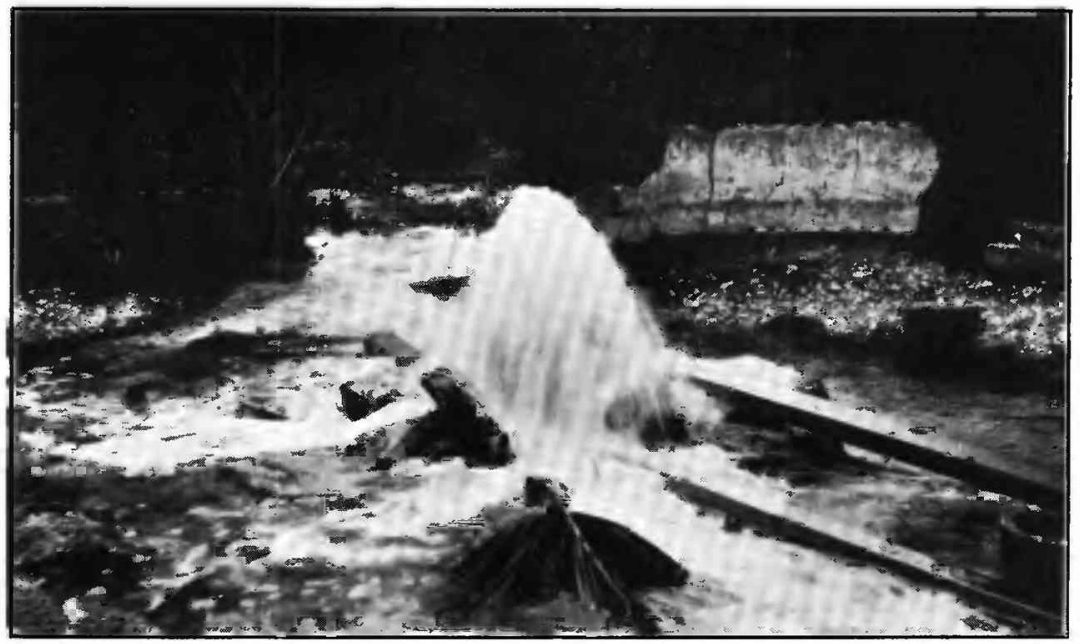

B. WELL 3, IN FLAGLER COUNTY, FLOWING ABOUT 750 GALLONS A MINUTE. 


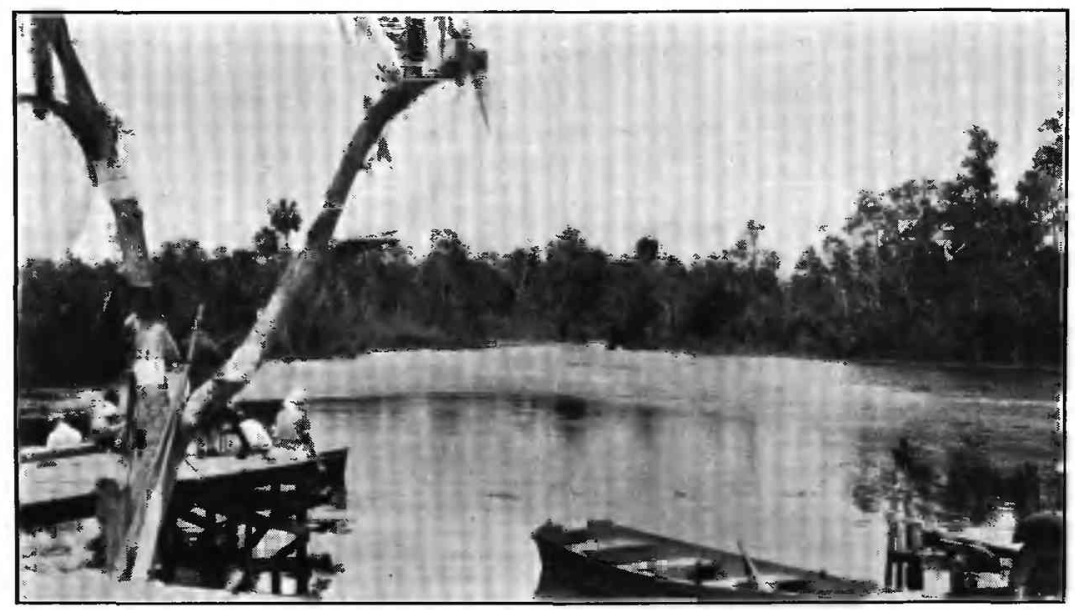

A. WEEKEWACHEE SPRING, HERNANDO COUNTY.

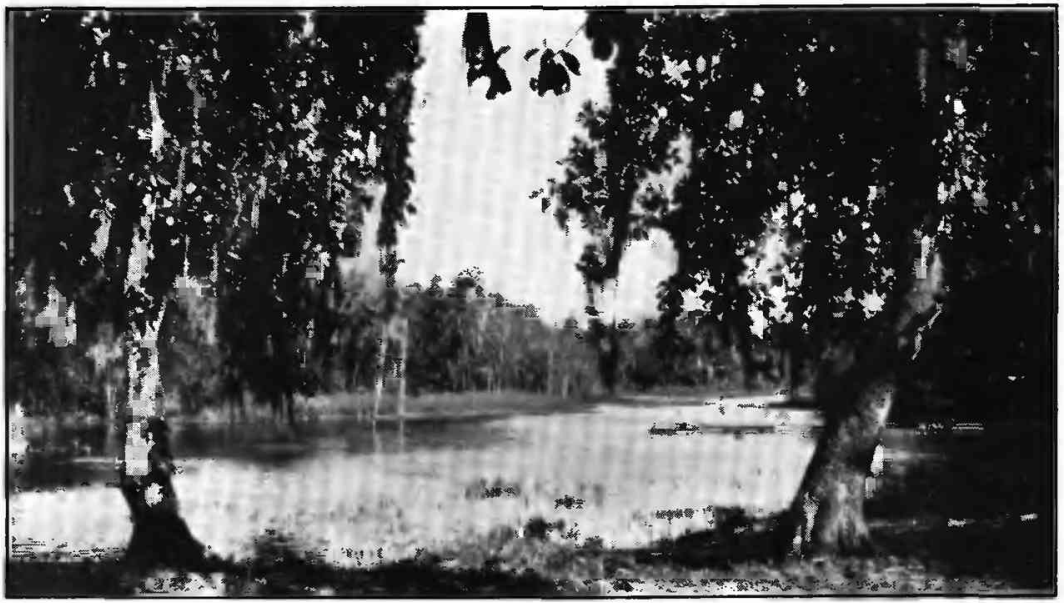

B. BLUE SPRINGS, MARION COUNTY. 
The hydraulic gradient in the eastern part of Nassau and Duval Counties is relatively low, but the piezometric surface is 55 to 60 feet above sea level. Such conditions might be expected because in that area the 0cala. limestone is overlain by about 500 feet of the Hawthorn formation with relatively impervious members, and the submarine outcrop of the Ocala is probably as mach as $70 \mathrm{mlles}$ off the coast.

\section{Marion County area}

In Marion County the piezometric surface forms a broad saddle, about 40 to 50 feet above sea level, between the Putnam County area on the north and the Polk County area on the south. In this area the Ocala limestone is at or near the surface, and sink holes are well developed, affording favorable conditions for recharge. Large recharge doubtless takes place, and the area also receives some water from the Polk County and Putnam County areas. The limestone in this area is porous and in part cavernous, and the water may move freely through it. During and after periods of large rainfall part of the saddle is as much as 10 feet higher than in normal times. Under such conditions the 50-foot contour lines, instead of closing on the north and south side of the saddle, as mapped in plate 12, will extend along the east and west parts of the saddle and connect the Polk County area with the Putnam County area.

This is also an area of very large discharge. It furnishes water for Silver Springs and Blue Springs (pls. 13, A, and 14, A), two of the largest springs in the State. The discharge of these springs, with a combined maximum flow of about 2,000 second-feet, 50 or about 896,000 gallons a minute, in part causes the saddle in the piezometric surface. Part of the ground water from the Marion County area flows eastward into the easterm part of Marion County, and part of it flows westward into Levy and Citmus Counties.

\section{Volusia County area}

One of the most extensive low-pressure areas in the peninsula is in Volusta and Flagler Counties and parts of the adjacent counties, where the piezometric surface is only about 10 to 20 feet above sea level. This low pressure is caused in part by the discharge of ground water through springs in the St. Johns River Valley and submarine discharge through springs and outcrops in the Atlantic Ocean. One of these submarine

50 Discharge measurement made by D. S. Wallace, district engineer, J. S. Geological Survey. 
springs is about $2 \frac{1}{2}$ miles offshore east of Crescent Beach. A similar spring is reported near Port Orange, which lies just south of Daytona Beach, In Volusia County. A large spring is reported about 16 miles off the coast east of a point about midway between Coronado Beach, in Volusia County, and Canaveral, in Brevard County.

Extending from the southeasterm part of Putnam County into the northwestern part of Volusia County is a long, narrow district between the St. Johns River Valley and Crescent Lake in which the piezometric surface is from 20 to 30 feet above sea level. Sink holes and lakes occupying old sink holes afford opportunity for recharge, which accounts in part for this ridge in the piezometric surface. There is a similar area, including De Land, Orange City, and Lake Helen, in the southwestem part of Volusia County east of the St. Johns Valley, but the piezometric surface in that area lies in the interval between 10 and 20 feet above sea level and is not shown by a contour line.

\section{Hillsborough County area}

The plezometric surface in Hillsborough County ranges from less than 10 feet to more than 50 feet above sea level. At Port Tempa (see well 16, p. 168) it is only about 3 feet above sea level. From Tampa and vicinity northeastward to Pasco County the piezometric surface has the shape of a valley that heads in a saddle in Pasco County and lies between the Pasco County and Polk County areas. This valley is caused in part by leakage of artesian water through springs in the outcrops of the Tampa limestone along the valley of the Hillsborough River. The largest of these springs is Sulphur Spring, near Tampa, and one of the best known of the smaller ones is Crystal Springs, near the town of Crystal Springs.

\section{Citrus County area}

In Citrus County and adjacent parts of Hernando and Levy Counties the plezometric surface slopes from an altitude of about 40 feet in the easterm part of the area to less than 5 feet in the western part, on the Gulf coast. The artesian water in this area is supplied in part from the Marion County, Polk County, and Pasco County areas. The Ocala limestone or the Tampa limestone is at or near the surface, and sink holes are well developed, especially in Citrus County, facilitating local recharge. The Ocala limestone is porous and even cavernous and thus per- 
mits fairly free movement of the water. The general direction of movement is toward the west, and most of this water appears as springs on the west coast.

The alinement of some of the sink holes in Citrus County is in an east-west direction, indicating the course of some of the underground streams. Such an alinement might be expected, because the contours representing the piezometric surface indicate movement of the ground water toward the west. In the northern part of Citrus County, along the Withlacoochee River, the ground-water level during normal stages is about the same as the water level in the river. During flood stages the river may lose water to the Ocala Iimestone.

\section{Suwannee River area}

The piezometric surface forms a valley along the Suwannee River, and the ground-water level in the bottom of the valley is generally about the same as the water level in the river. The piezometric surface slopes from about 50 or 60 feet above sea level near the State line on the north to less than 10 feet above sea level on the Gulf of Mexico. On both sides of the valley it rises to 50 feet or more above sea level. The gradient on the east side, however, is lower than that on the west.

The Ocala and Tampa limestones are present at the surface in this area and thus receive recharge. During low stages of the Suwannee River its flow is largely derived from ground water, but during flood stages it loses water to the formations. These relations between surface water and ground water also exist along the lower course of the Santa Fe River, a tributary of the Suwannee.

Near Falmouth, in Suwannee County about 3 miles east of the Suwanne River, a small section of the roof of an underground stream has collapsed, and the stream is exposed at the surface. It is known as Falmouth Spring. During normal stages of the Suwannee River the water level of Falmouth Spring is a few feet higher than the river and water from the spring flows westward to the river. However, during flood stages the river is somewhat higher than the spring and contributes water to the underground stream and the flow of Falmouth Spring is reversed. 


\section{Southern Florida}

The plezometric surface in southern Florida ranges from a few feet to about 50 feet above sea level. In most of the area it is relatively flat and more than 30 feet above sea level. In the southern part of the area only a few wells penetrate the lower part of the Hawthorn formation and the underlying rocks, and therefore only a few control points are avallable to represent the piezometric surface. According to records of wells 1, 2, and 3 on the Florida Keys, in Monroe County (p. 183), the piezometric surface is approximately at sea level in that area. Records of wells 1 and 2 at Mlami, in Dade County, indicate that the piezometric surface is there 40 feet or more above sea level. It thus appears to slope southward toward the Florida Keys.

The artesian water-bearing formations are deeply buried in this area, and no recharge takes place locally. Fresh water enters the formations in the Polk County area, but the low hydraulic gradient indicates that there is slight movement of artesian water toward the south. The ocean floor is more than 2,000 feet below sea level about 20 to 30 miles of the coast in the Straits of Florida, and therefore it appears 1ikely that the formations have submarine outcrops within that distance offshore. The artesian pressure in part of the area appears sufficient to overcome back pressure from the salt water on the submarine outcrops, and some artesian water is escaping through them. The low pressure in the wells on the Florida Keys might be suggested as an indication of leakage through outcrops in the Straits of Florida, but this appears unlikely, because the pressure is not sufficient to displace the salt water at the submarine outcrops. Such low pressures will permit encroachment of sea water in the area if the formations are sufficiently permeable, and the high salinity of the water in wells on the Florlda Keys may be attributed to sea water.

Information regarding the casing in the wells on the Keys is meager. and it is entirely possible that if the casing is insufficient subsurface leakage may occur. Under these conditions the head in the wells may be reduced approximately to sea level. On the other hand, the Florida Keys are at a considerable distance from the recharge area of the artesian formations. The formations appear to become thicker and less permeable toward the south, and although the general direction of movement of the ground water is southward some of it moves to the east and west, and smaller amounts of this water reach the Florida Keys. 


\section{Springs}

Most of the large springs of the peninsula yield water under artesian pressure from the $0 \mathrm{cala}$ and Tampa limestones and are situated in parts of the northerm half of the peninsula where these formations are at or near the surface. The Hawthorn formation is the source of a few of the large. springs, such as Rock Spring, in Orange County, and of numerous smaller springs. In the northeastern and southern parts of the peninsula, where the formations are deeply buried, no large springs are present. The following list represents the largest springs in the peninsula, and plate 15 shows their distribution. The discharge measurements have been furnished by D. S. Wallace, of the United States Geological Survey. Among the var- . ious reports that contain data on the springs of Florida, a paper by Meinzer includes a description of some of the large springs.

Large springs in the Florida peninsula

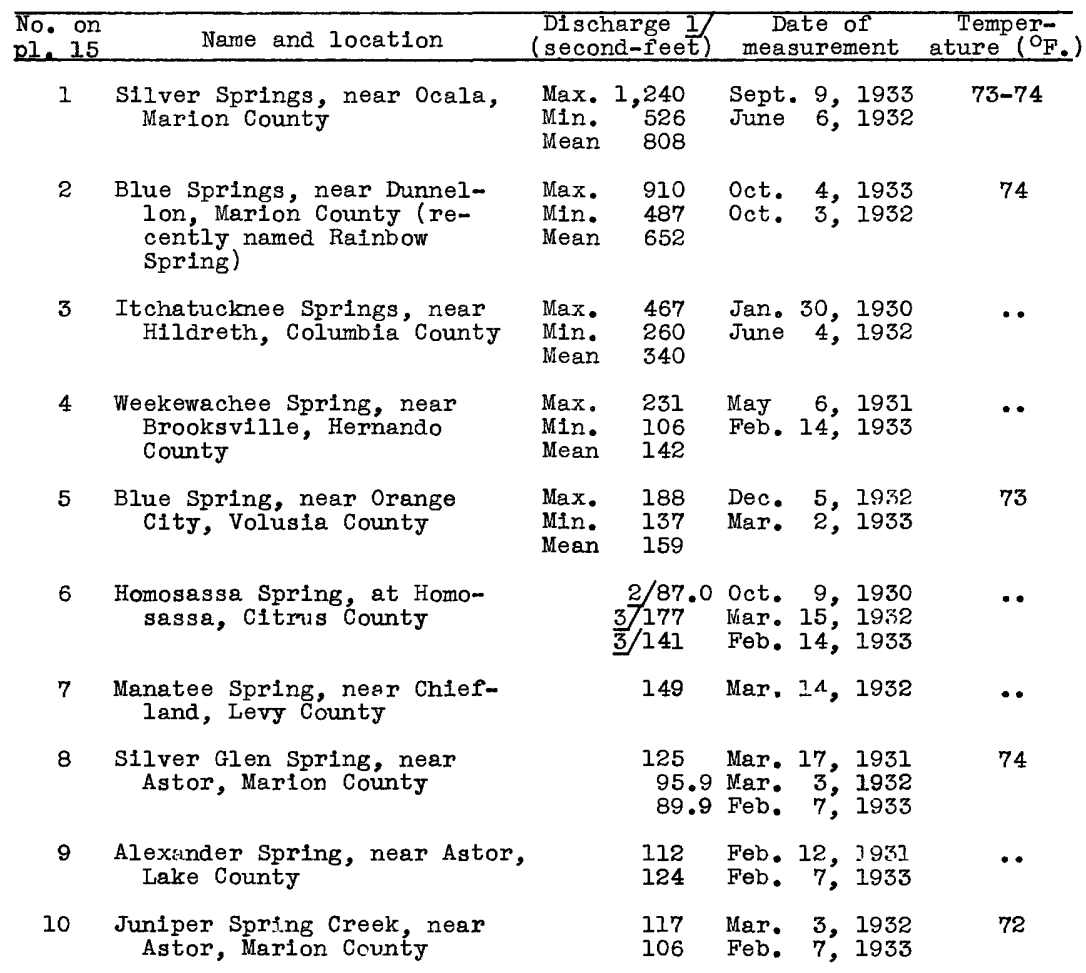

1 One second-foot equals 448.8 United States gallons a minute, or 646,317 gallons a day. Mean represents the average of measurements made to date.

2 only main spring. Estimate 42 second-feet in second channel.

3 All springs.

51 Meinzer, 0. E., Large springs in the United States: U. S. Geol. Survey Water-Supply Paper 557, pp. 8-13, 1927. 
Large springs in the Florida peninsula - Continued

\begin{tabular}{|c|c|}
\hline $\begin{array}{l}\text { No. on } \\
\text { pl. } 15 \\
\end{array}$ & Name and location \\
\hline 11. & $\begin{array}{l}\text { Fannin Spring, near Wilcox, } \\
\text { Levy County }\end{array}$ \\
\hline 12 & $\begin{array}{l}\text { Salt Spring, at Lake Kerr, } \\
\text { Marion County }\end{array}$ \\
\hline 13 & $\begin{array}{c}\text { Chassahowitska Spring, near } \\
\text { Homosassa, Citmus County }\end{array}$ \\
\hline 14 & $\begin{array}{l}\text { Wekiva Spring, near Gulf Ham- } \\
\text { mock, Levy County }\end{array}$ \\
\hline
\end{tabular}

Sulphur Spring, near Tampa, Hill sborough County

Poe Spring, near High Springs, Alachua County

Hunter Spring, at Crystal River, Citrus County

Blue Spring, near Lee, Madison County

White Spring, at White Springs, Hamizton County

Wekiva Spring, near Apopka, Orange County

21 Crystal Springs, near Crystal Springs, Pasco County

Rock Spring, near Apopka, Orange County

Kissengen Spring, near Bartow, Polk County

Swanacoochee Spring, at Ellaville, Madis on County

25

26

Seminole Spring, near Sorrento, Lake County

Ponce de Leon Spring, near $\mathrm{De}$ Land, Volusia County

27

Discharge
second-feet) Date of $\begin{gathered}\text { Temper- } \\ \text { mesurement ature (OF,) }\end{gathered}$

$\begin{array}{rrlr}\text { Max. } & 105 & \text { May } 5,1931 \\ \text { Min. } & 61.8 & \text { Feb. } 7,1933 \\ \text { Mean } & 85.1 & & \\ & 4 / 101 & \text { Oct. } 9,1930 \\ 98.1 & \text { Mar. 15, } 1932 \\ & & \\ 64.7 & \text { Feb. 21, } 1917 \\ 100 & \text { Feb. 1, } 1929 \\ 75.2 & \text { Oct. 25, } 1930 \\ 81.3 & \text { Feb. 9, } 1931 \\ & 55.1 & \text { Mar. 16, } 1932\end{array}$

Max.

Min.

Mean

92.3 May 9, 1930

12.9 Feb. 12, 1934

45.1

86.5 Feb. 19, 1917

31.2 Mar. 14, 1932

15.6 Mar. 15, 1932

$87.0 \mathrm{Feb} \cdot 14,1933$

5/75.0 Mar. 16, 1932

55.9 Feb. 5, 1931

51.9 Mar. 8, 1932

54.2 Feb. 10, 1933

19.2 June 11,1932

30.2

40.8 Nov. 6,1931

18.3 Mar. 16, 1932

27.1 Feb. 5, 1931

6/10.2 Mar: 8, 1932

$35.8 \mathrm{Feb}$. 10, 1933

22.0 Feb. 1I, 1929

20.4 Mar. 7, 1932
67.2 May 8, 1927

46.4 Mar. 17, 1932

43.1 Apr. 20, 1932

63.9 Mar。 8, 1932

66.9 Feb. 10, 1933

74

57.4 Jan. 6, 1933

53.0 Feb. 17,1933

67.2 Jan. 15, 1934

57.7 oct. 25,1934

43.6 Oct. 11,1933

73

........... $\quad y / 71 \frac{1}{4}$

76

75

-

$\cdots$

$\bullet$

74

-

-

$\cdots$ east of Crescent Beach, St. Johns County

4 Total flow of river.

5 Estimated.

6 Does not include all springs. 7 Temperature at a depth of lil feet. Measured by the U. S. Coast and Geodetic Survey. 


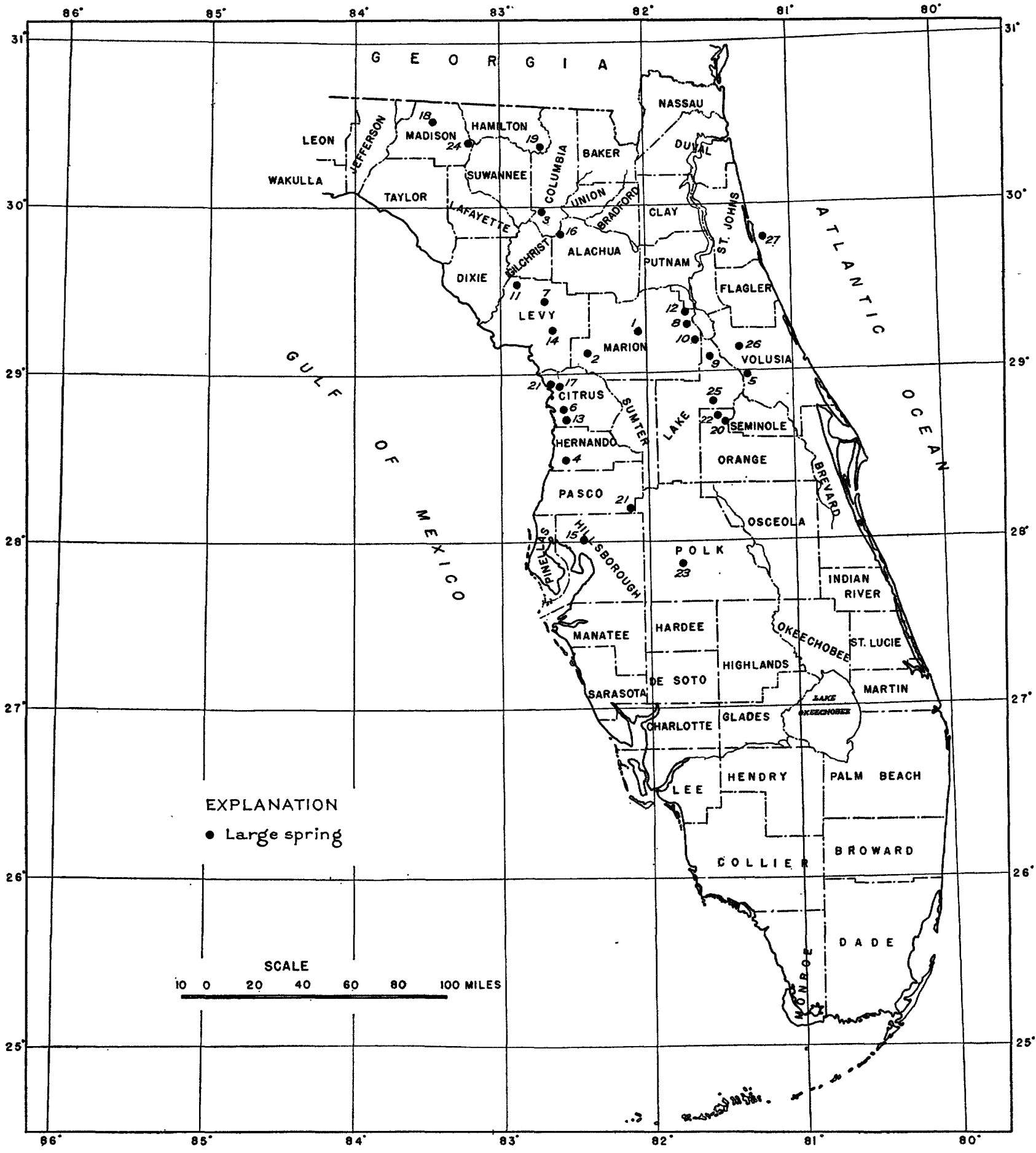

MAP OF FLORIDA PENINSULA REPRESENTING LOCATION OF LARGE SPRINGS. 
The two springs with the largest discharge are Silver Springs and Blue Springs, in Marion County. (See pls. 13, A, and 14, A.) Rock Spring, in Orange County, is one of the few large springs with an outlet of the underground stream in part above the water level. Most of the large springs emerge more or less vertically as boils out of deep pools. One of the deepest of these pools is that of Weekewachee Spring, in Hernando County, which, according to measurements made by D. G. Thompson and the writer, has a depth of about 145 feet. (See pl. 14, B.)

Submarine springs are reported to be present of $I$ the coast east of the Volusia County area. One of them is about $2 \frac{1}{2}$ miles east of Crescent Beach. The location of this spring and the depth of water in it have been charted. This spring has been described by A. M. Sobieralski, of the U. S. Coast and Geodetic Survey. ${ }^{53}$ It was visited by the writer in 1934. The ocean floor at the spring is about 55 feet below sea level, and the bottom of the spring is as much as 125 feet below sea level. The spring has sufficient pressure and discharge to be noticeable at the surface of the ocean. The water, like much of the artesian water in Florida, contains hydrogen sulphide. According to the appearance of the discharge at sea level the orifice of the spring may be as much as 200 feet in diameter. No discharge measurements were made, but the discharge may be comparable to that of some of the larger springs in the peninsula. This spring is probably the same as that referred to by Matson and Sanford.

\section{Welts}

\section{General features}

Records of representative artesian wells in various parts of the peninsula are shown in the table on pages 165 to 189, which also includes a few records of wells representing water-table conditions. The areas in which the artesian wells will flow under natural pressure are shown in plate 10, and the height to which the water will rise in tightly cased wells is shown on plate 12 and in the tables. The artesian wells range from about 50 feet to more than 1,000 feet in depth, depending on the local conditions within the area in which they are constructed. The wells range from about 2 inches to more than 12 inches in diameter. Few

52 U. S. Coast and Geodetic Survey Chart 3258, Florida inside route, St. Augustine to Titusville, 1931.

53 Rude, G. T., St. Augustine and its oceanic spring: Geog. Soc. Philadelphia Bul1., vol. 23, no. 3, pp. 85-91, 1925. $213,397$.

54 Matson, G. C., and Sanford, Samuel, op. cit., pp. 207, 218, 
of the wells are entirely cased, and the casing usually terminates in the top of the first consolidated limestone penetrated. Some wells as much as 1,000 feet deep may have only about 100 feet of casing. Generally the wells are equipped with valves, so that the flow can be controlled or shut off. However, a few wells are not equipped with valves and permit continuous waste of water. (See pl. 13, B.)

Most of the artesian wells are within the areas in which the wells flow, and the greatest concentrations are in irrigation districts, as in Sarasota, lifanatee, and Seminole Counties. In parts of the irrigation districts in Seminole County there is an average of one or more wells for each acre of land irrigated. In some of the larger cities, such as Jacksonville, wells are numerous. There are also a large number of nonflowing artesian wells used for surface drainage in and near Orlando, in orange County. A few of the flowing artesian wells are used for drainage on the east coast.

The capacity of the wells depends on the hydrologic conditions and the construction of the wells. In general the wells with the smallest capacities are in the southern part of the peninsula. In Sarasota County $^{55}$ some of the deeper wells that penetrate the Hawthorn formation, the Tampa limestone, and the Ocala limestone yield little or no water from the Tampa and Ocala, the artesian formations that yield large supplies of water to wells except in the southern part of the peninsula. The yield of flowing artesian wells under natural flow ranges from a few gallons to more than 1,000 gallons a minute. The largest yields by natural flow are in the eastern and northeasterm parts of the peninsula, where the artesian pressure is relatively large and the surface of the ground is only a few feet above sea level. One of the largest yields observed was about 2,000 gallons a minute from a well 8 inches in diameter at Crescent Beach (well 20, St. Johns County). The largest reported yield by natural flow is 6,200 gallons a minute from well 2 in Brevard County, a 12-inch well.

When wells are flowing under natural artesian pressure, the pressure at the mouth of the well is almost zero, so that the draw-down, or loss in head resulting from the discharge of water, is almost equal to the head with reference to the outlet of the well. Such temporary loss in head for different flowing wells in different parts of the peninsula

55 Stringfield, V. T., Exploration of artesian wells in Sarasota County, Florida: Florida Geol. Survey 23d-24th Ann. Rept., pp. 202-214, 220 , 1933. 
has been observed to range from a fraction of a foot to about 45 feet. Obviously, the maximum loss of head in a flowing well is limited to the shut-in head. The results of the losses of head may be expressed in terins of specific capacity, which is the number of gallons discharged per unit loss of head. The specific capacity is significant for comparison of yield of different wells and for determining the loss of head that will result if the yield of the well is increased by pumping. Data regarding the specific capacities of a few wells for which calculations could be made are shown in the following table:

Specific capacity of artesian wells in Florida peninsula

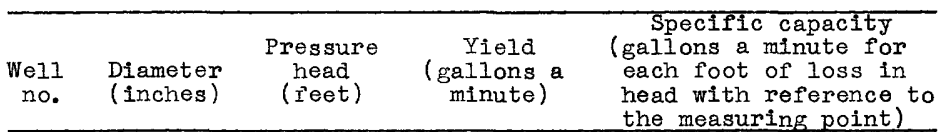

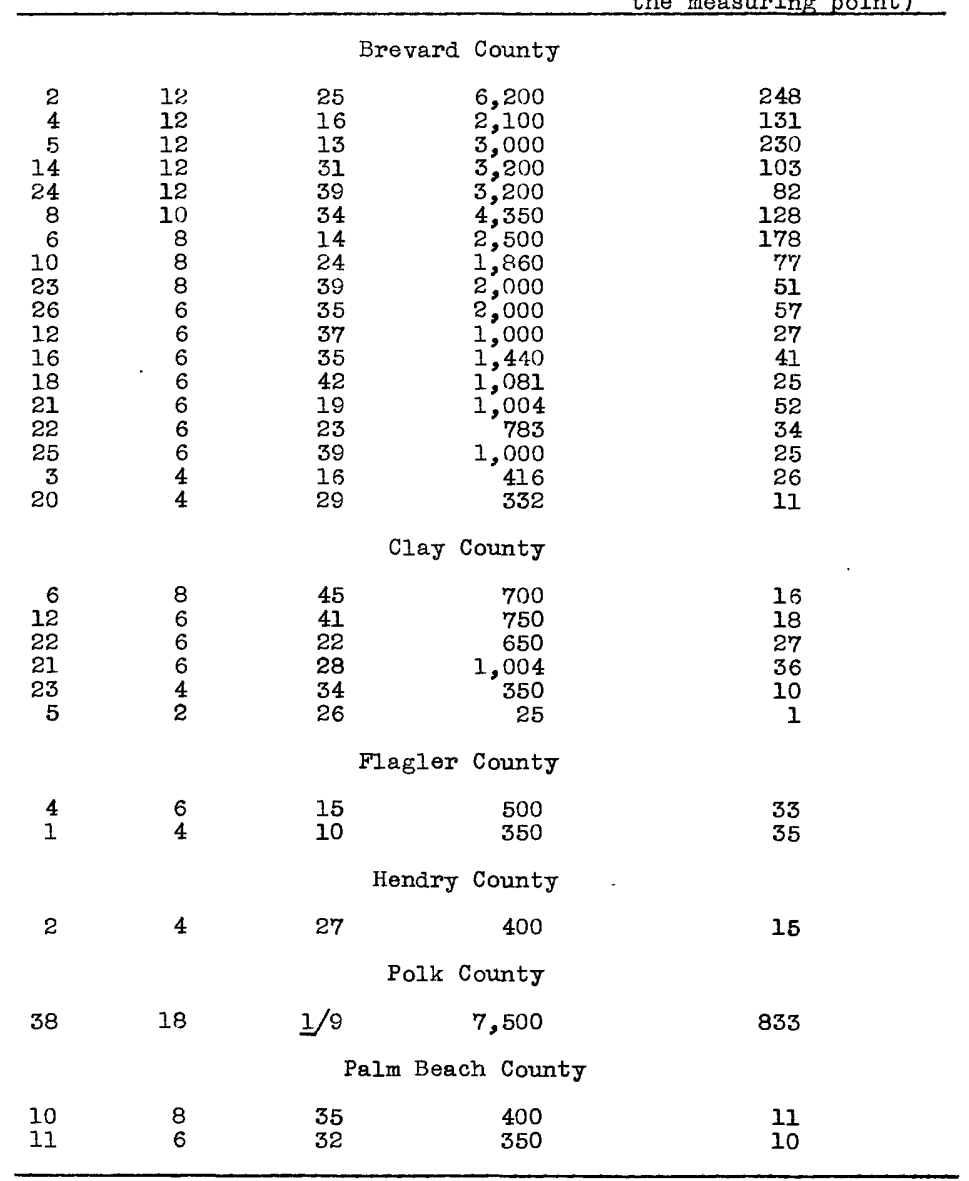

1 Draw-down in nonflowing well. 
The largest yield recorded from a nonflowing well in the peninsula is 7,500 gellons a minute from well 38 in Polk County. The discharge measurement was made in 1926 by the American Agricultural Chemical Co.

\section{Subsurface leakage of wells}

Few of the artesian wells in the peninsula are completely cased, and in many of them the uncased parts extend through water-bearing beds at several horizons. Under such conditions water entering the well from beds with relatively high artesian pressure may escape into beds with lower pressure instead of rising to the surface or remaining confined in the well. The artesian pressure of the water in the middle and upper parts of the Hawthorn formation in different localities may be higher or lower than the artesian pressure of water in the underlying part of the Hawthorn and the Tampa and 0cala limestones. Wells penetrating these formations may have subsurface leakage unless they are properly cased.

In Baker County and elsewhere in the northern part of the peninsule the artesian head of the middle and upper parts of the Hawthorn formation. is higher then that in the lower part and the underlying Ocale limestone. Wells drilled into the Ocale in that area should therefore be cased to prevent leakage from the upper beds into the lower beds. East of that area, in Duval and Nassau Counties, and in most of the other parts of the peninsula where the Hawthorn formation is present the pressure in the Hawthorn formation is less than that in the underlying limestones, and subsurface leakage in wells may occur by loss of water to the Hawthorn formation. The observed difference in head ranges in different parts of the peninsula from a fraction of a foot to as much as 40 feet.

Exploration of artesian wells in the northwestern part of Sarasote 56

County revealed no underground leakage in wells in that locality. However, it is entirely possible that some leakage had taken place but that the pressure of the beds at the two horizons was at equilibrium at the time the tests were made.

We.l. data collected subsequent to that work indicate that underground leakage occurs in other localities. On the west coast of Manatee County wells that will flow are reported to have been nonflowing during conscruction, before their upper parts were cased.

56 Stringfield, V. T., Exploration of artesian wells in Sarasota County, Florida: Florida Geol. Survey 23d-24th Ann. Rept., pp. 199-2l6, 1933. 
Near Sun City, in the southwestern part of Hillsborough County, a well 340 feet deep was reported to be nonflowing until well 14 at sun City, 550 feet deep, with only 42 feet of casing, was constructed, thus indicating that part of the water from the rocks penetrated by well 14 that normally would rise to the surface through that well enters the rocks penetrated by the 340-foot well.

A well in the town of Green Cove Springs (well 14, Clay County) is reported to have had a pressure head of about 21 feet above the surface of the ground in 1927, when it was constructed. In 1934 it had a reported pressure head of 1.5 feet above the surface of the ground, or about 24 feet above sea level. Other wells observed in that vicinity had pressure heads of about 40 feet above sea level. Even though well 14 is reported to be cased to a depth of about 400 feet below the surface, the loss of head in that well may be caused by leakage through defective casing. Although the loss of head may be attributed to other causes, the inference of underground leakage is substantiated to some extent by the reports that the water level in this well is influenced by fluctuations in Green Cove Springs, a few hundred yards to the east. The water of Green Cove Springs comes from a relatively shallow source and should not influence the water level in a well cased to a depth of 400 feet unless there is some defect in the casing.

\section{Surface drainage into wells}

In some parts of the lake region and other localities where the surface drainage is poorly developed and the ground water stands several feet below the surface in wells, surface water is drained into wells constructed for that purpose. The drainage wells are located in sink holes or other depressions, along margins of lakes, or in ditches, in order that the mouths of the wells will be lower than the area drained. Probably the largest number of arainage wells is in and near Orlando, in Orange County, where more than 120 wells penetrating the 0cala limestone are in use for drainage. About 90 of the wells are owned by the city of Orlando, and practically all the sewage and run-off from rainfall in the city is disposed of through drainage wells. About 30 wells are owned and operated by the highway department of Orange County for drainage of roads in the county. The wells range from about 6 to 16 inches in diameter and from about 160 feet to more than 800 feet in depth. In parts of Orange County the static water levels representing the piezometric surface of the water 
In the 0cala limestone, as measured in wells, range from a few feet to as much as 60 feet below the surface of the ground. The estimated drainage capacities of the wells range from less than 100 gallons to several thousand gallons a minute. The maximum capacity reported was 9,500 gallons a minute for well 50 (county well 16), about 4 miles northeast of Orlovista. The effect of recharge through drainage wells in Orange County has been described above. Notes on drainage wells in the peninsula are included in several reports.

$$
57
$$

Areas of highly mineralized water and their relation

to the piezometric surface

Numerous field determinations of the chloride content of ground water, both artesian and nonartesian water, were made during the investigation. On the basis of these tests together with many published and a few unpublished analyses of water, the general areal extent of relatively highly mineralized ground water was outlined. According to the records of deep wells it appears that salt water underlies the entire peninsula. However, it is confined to rocks of great depths except in certain coastal areas and in the southern part of the state. The areas in which the chloride content of the water is more than about 100 parts per million at relatively moderate depths are represented in plate 16. The area on the east coast includes part of St. Johns County and extends from that county to the southern part of the peninsula and as far inland as the eastern parts of lifarion, Lake, and Seminole Counties, including part of the valley of the St. Johns River.

Salt Spring, in Marion County, nne of the larger springs in the peninsula, yields salt water. There are other small salt-water springs along the valley of the St. Johns River. As may be noted on plate 16, there are within this area two districts in which the ground water at moderate depth is $10 \mathrm{w}$ in chloride content. One extends as a narrow strip from southeastern Putnam County into northwestern Volusia County between the valley of the St. Johns River and Crescent Lake. The other is in the southwestern part of Volusia County, east of the St. Johns

57 Sellards, E. H., A preliminary report on the underground water supply of central Florida: Florida Geol. Survey Bull. I, pp. 60-67, 1908; Some Florida lakes and lake basins: Florida Geol. Survey 3d Ann. Rept., pp. 68-76, 1910. Stringfield, V. T., Ground-water investigations in Florida: Florida Geol. Survey Bull. 11, pp. 19-24, 1933.

58 Collins, W. D., and Howard, C. S., Chemical character of the waters of Florida: U. S. Geol. Survey Watér-Supply Paper 596-G, 1928. 


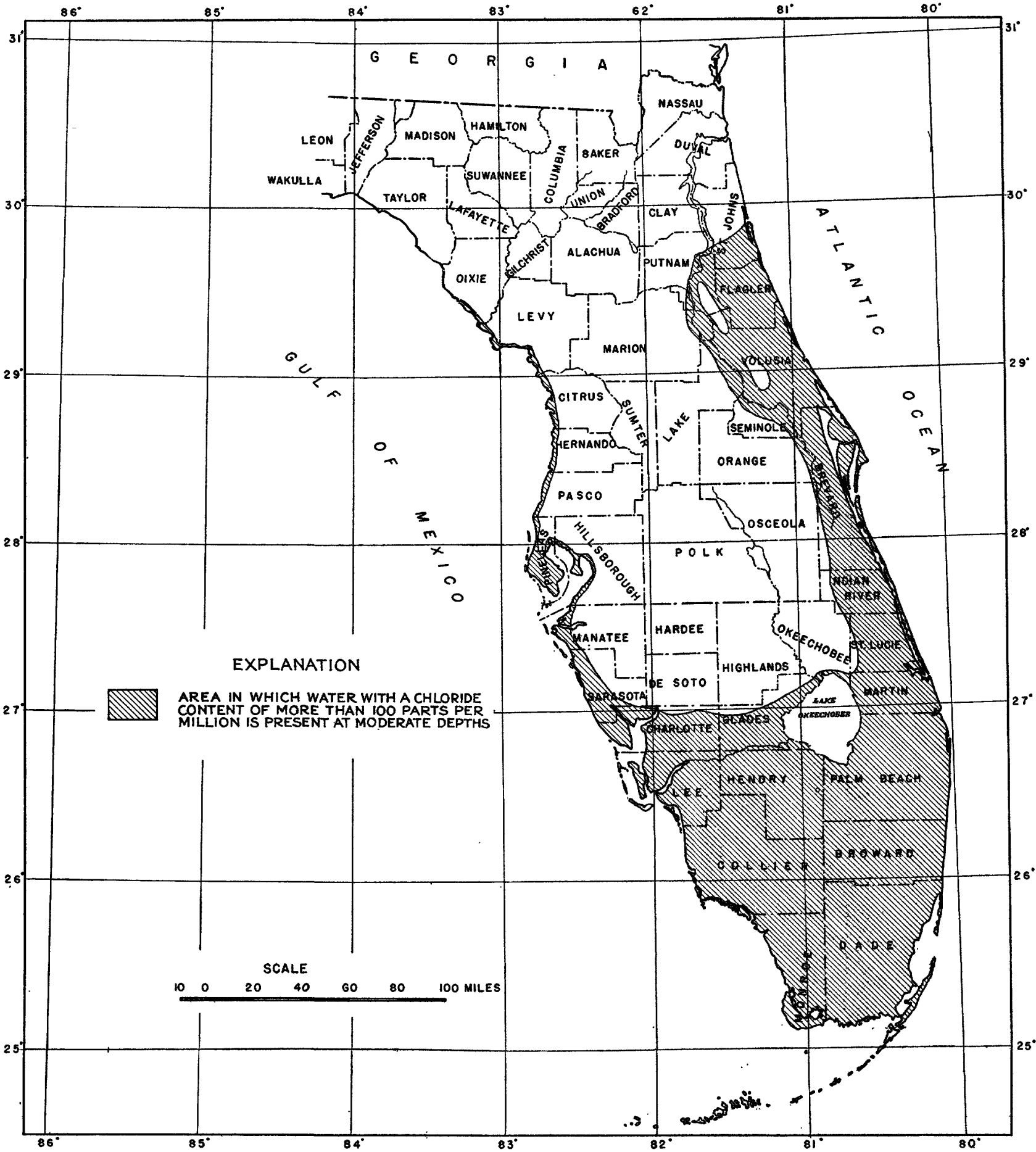

MAP OF FLORIDA PENINSULA REPRESENTING AREAS IN WHICH HIGHLY MINERALIZED WATER IS PRESENT AT MODERATE DEPTHS. 
River Valley. These are within local areas in which the piezometric surm face is relatively high.

The area of relatively highly mineralized water extends through the southerm part of the state and occupies a narrow belt on the west coast. Forturately the shallow water in most of the Florida peninsula has relatively low mineral content, and with careful development water supplies suitable for public and private consumption have been obtained and may be obtained in the future from that source.

Certain general relations between salt and fresh water in coastal 59 areas are known and have been summarlzed by Brown. The general relations in Sarasota County have been described by the miter. 60 The principle of equilibrium between salt and fresh water as applied to the hydrology of seacoasts is sometimes referred to as the ntheory of Ghyben and Herzberg $n^{61}$ and may be expressed by the formala $\underline{h}=\frac{t}{g-1}$, in which $\underline{h}$ is the depth of fresh water belor sea level, $t$ is the height of fresh water or hydrostatic head above sea level, and $g$ is the specifle gravity of the salt water. The specific gravity of sea water raries somewhat from one locality to another and may also be different at different depths. Where the specific gravity of the sea water is 1.025 the fresh water will extend 40 feet below sea level for every foot that the ground water stands above sea level. This theory is applicable in a general way to the artesian conditions in the Florida peninsula. In the central part of the peninsula, where the pressure is high, the salt water occurs only at great depths, but in the cosstal areas, where the pressure is 10w, salt water is present at shallow or moderate depths. This general relation is also present locally, as in Putnam and Volusia Counties, where water of relatively low mineral content is found in an area where the plezonetric surface is high, and highly mineralized water is found in adjacent areas of low pressure head.

In several of the coastal areas where highly mineralized water is present, the pressure of the artesian water is sufficient to cause the water to discharge through submarine springs, and no encroachment of sea water is now occurring, but encroachment may occur if a sufficient lowerlng of pressure takes place.

59 Brown, J. S., A study of coastal ground water, with special reference to Connecticut: U. S. Geol. Survey Fater-Supply Paper 537, 1925.

60 Stringfield, V. T., Ground-water resources of Sarasota County, Fla.: Flor1da Geol. Survey 23d-24th Ann. Rept., pp. 167-177, 1933.

61 Brown, J. S., op. c1t.', p. 16. 
A well at Titusville, in Brevard County, is reported to have penetrated a thin bed of salt at a depth of about 50 feet below the surface. Although this is the only record of the presence of salt that has been reported, it appears likely that salt as thin beds or disseminated in the materials penetrated might escape notice. Salt water resembling sea water in composition but more than twice as concentrated as sea water was penetrated at moderate depth in Manatee County. 63 Under these conditions the contamination of the artesian water must be caused by the presence of salt water or mineral salts within the formation, and thus the flushing action of the artesian water is one of the controlling factors in the present distribution of the highly mineralized water.

62 Matson, G. C., and Sanford, Samuel, op. cit., p. 276.

63 Stringfield, V. T., Exploration of artesian wells in Sarasota County, Fla.: Florida Geol.' Survey 23d-24th Ann. Rept., p. 219, 1933. 
Records of wells in the Florida peninsula

Date on wich the well was completed, depth and diameter of the well, probable geologic formation that is the principal source of the water, depth to which the well is cased, pressure head or level of the water expressed in feet above (+) or below (-) the measuring point, date of measurement, altitude of measuring point (M. P.) referred to mean sea level, and use and temperature of the water. Abbreviations: 0 , Ocala limestone; H, Hawthorn formation; $T$, Tampa IImestone; $R$, rallroad water supply; $P$, public water supply; N, water not used; Ind., Industrial use; Irr., Irrigation; $D$, domestic; $K$, medicinal; F, flre protection; $A$, swiming pool, park, tourist camp, etc.; Dr., draindomestic; M, medicinal; F, flre protection; A, swiming pool, park, tourist camp,
age; B, supply for boat basin; $\mathrm{S}$, stock. See pages 175-189 for further detalls,

\begin{tabular}{|c|c|c|c|c|c|c|c|c|c|c|}
\hline \multirow{2}{*}{ No. } & \multirow{2}{*}{$\begin{array}{l}\text { Date } \\
\text { com- } \\
\text { pleted }\end{array}$} & \multirow{2}{*}{$\begin{array}{l}\text { Depth } \\
\text { (feet) }\end{array}$} & \multirow{2}{*}{$\begin{array}{l}\text { Diameter } \\
\text { (Inches) }\end{array}$} & \multirow{2}{*}{ Bource } & \multirow{2}{*}{$\begin{array}{l}\text { Depth of } \\
\text { casing } \\
\text { (feet) }\end{array}$} & \multicolumn{2}{|c|}{ Water level } & \multirow{2}{*}{$\begin{array}{l}\text { M. P. } \\
\text { (feet) }\end{array}$} & \multirow{2}{*}{ Use } & \multirow{2}{*}{$\begin{array}{l}\text { Temper- } \\
\text { ature } \\
\left(\mathrm{O}_{\mathrm{F}}\right)\end{array}$} \\
\hline & & & & & & Feet & Date & & & \\
\hline
\end{tabular}

\begin{tabular}{|c|c|c|}
\hline $\begin{array}{l}1 \\
2 \\
2 a \\
3 \\
4 \\
5 \\
6\end{array}$ & $\begin{array}{c}\text { Feb. } 1929 \\
1913 \\
1913 \\
\text { sept. } \\
\ldots \ldots \\
\ldots \ldots\end{array}$ & $\begin{array}{r}250 \\
383 \\
415 \\
378 \\
80 \\
118 \\
75 \\
155\end{array}$ \\
\hline $\begin{array}{l}8 \\
9 \\
9 a \\
10 \\
11 \\
12 \\
13 \\
4 \\
15 \\
16 \\
17 \\
18\end{array}$ & 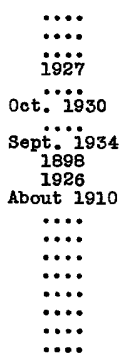 & $\begin{array}{r}116 \\
42 \\
35 \\
390 \\
442 \\
335 \\
1,000 \\
243 \\
395 \\
190 \\
97 \\
75 \\
44 \\
92 \\
58 \\
218 \\
115 \\
115 \\
135\end{array}$ \\
\hline
\end{tabular}

Alachua County

\begin{tabular}{|c|c|c|c|c|c|c|c|c|}
\hline $\begin{array}{c}\text { Feb. } 1933 \\
\ldots \ldots \\
\ldots \ldots \\
\ldots \ldots\end{array}$ & $\begin{array}{r}236 \\
94 \\
137 \\
175 \\
165\end{array}$ & $\begin{array}{l}4 \\
2.5 \\
2 \\
2 \\
6\end{array}$ & $\begin{array}{c}\mathrm{H}, \mathrm{O} \\
\mathrm{H} \\
\mathrm{H} \\
\mathrm{H} \\
\mathrm{H}\end{array}$ & $\begin{array}{l}212 \\
\ldots \\
\ldots \\
\ldots\end{array}$ & $\begin{array}{l}-90 \\
+15 \\
-30 \\
-11.5 \\
-66\end{array}$ & 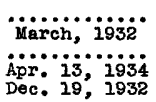 & $\begin{array}{l}165 \\
50 \\
128 \\
131 \\
134.6\end{array}$ & \\
\hline
\end{tabular}

$\begin{array}{lllll}1 & 1900 & 529 & 5 & 0 \\ 2 & 1928 & 580 & 10 & 0 \\ 3 & \cdots \cdots & 90 & 3 & \text { H } \\ 4 & \cdots 33 & 250(?) & 5.5-2.5 & H \\ 5 & 193 i & 120 & 4 & H\end{array}$

Bradord County

\begin{tabular}{|c|c|c|c|c|}
\hline $\begin{array}{l}500 \\
500 \\
60 \\
250(?) \\
120\end{array}$ & $\begin{array}{l}-94.4 \\
-80 \\
-20 \\
-2 \\
-18\end{array}$ & $\begin{array}{l}\text { Nov. }{ }^{7}, 1934 \\
\text { Apr... } 1928,1934\end{array}$ & $\begin{array}{l}170 \\
166 \\
166 \\
148 \\
150\end{array}$ & $\begin{array}{l}P \\
\ddot{P} \\
\ddot{P}\end{array}$ \\
\hline
\end{tabular}

Brevard County

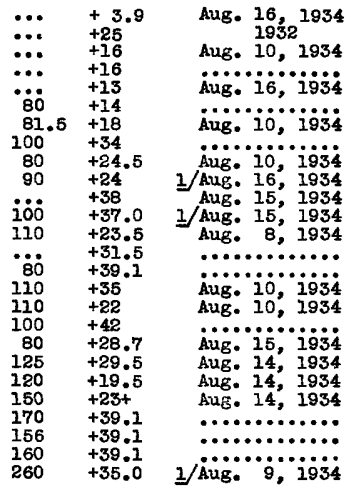

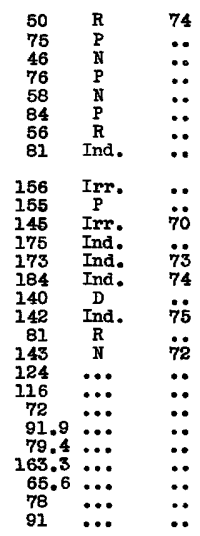

4
0
0
0
0
0
0
0

$\begin{array}{rcr}1 & 1332 & 400 \\ 2 & 1932 & 137 \\ 3 & 1922 & 400 \\ 4 & 1932 & 615 \\ 5 & 1932 & 415 \\ 6 & 1929 & 626 \\ 7 & 1890(\text { ) } & 313 \\ 8 & 1916 & 310 \\ 9 & 1931 & 420 \\ 10 & 1932 & 227 \\ 11 & 1932 & 350 \\ 12 & 1926 & 400 \\ 13 & \text { Sept. } 1927 & 511 \\ 14 & 1927 & 600 \\ 15 & 1928 & 400 \\ 16 & 1992 & 400 \\ 17 & 1927 & 300 \\ 18 & 1923 & 620 \\ 19 & 1929 & 413 \\ 20 & 1929 & 447 \\ 21 & 1927 & 610 \\ 22 & 1926 & 350 \\ 23 & 1929 & 872 \\ 24 & 1929 & 1,000 \\ 25 & 1922 & 630 \\ 26 & 1929 & 1,000\end{array}$

$\begin{array}{rl}132 & 0 \\ 4 & 0 \\ 12 & 0 \\ 12 & 0 \\ 8 & 0 \\ 4 & 0 \\ 10 & 0 \\ 8 & 0 \\ 4 & 0 \\ 6 & 0 \\ 6 & 0 \\ 6 & 0 \\ 12 & 0 \\ 6 & 0 \\ 4 & 0 \\ 6 & 0 \\ 6 & 0 \\ 2 & 0 \\ 4 & 0 \\ 6 & 0 \\ 6 & 0 \\ 8 & 0 \\ 12 & 0 \\ 6 & 0 \\ 8 & 0 \\ & 0\end{array}$

\section{Baker County}


Records of wells in the Florida peninsule - Continued

\begin{tabular}{|c|c|c|c|c|c|c|c|c|c|c|}
\hline \multirow{2}{*}{ No. } & \multirow{2}{*}{$\begin{array}{c}\text { Date } \\
\text { com- } \\
\text { pleted }\end{array}$} & \multirow{2}{*}{$\begin{array}{l}\text { Depth } \\
\text { (feet) }\end{array}$} & \multirow{2}{*}{$\begin{array}{l}\text { D1ameter } \\
\text { (1nches) }\end{array}$} & \multirow{2}{*}{ Source } & \multirow{2}{*}{$\begin{array}{l}\text { Depth of } \\
\text { cosing } \\
\text { (feet) }\end{array}$} & \multicolumn{2}{|c|}{ Water level } & \multirow{2}{*}{ (feet) } & \multirow{2}{*}{ Use } & \multirow{2}{*}{$\begin{array}{l}\text { Temper- } \\
\text { ature } \\
(\text { of.) }\end{array}$} \\
\hline & & & & & & Feet & Date & & & \\
\hline
\end{tabular}

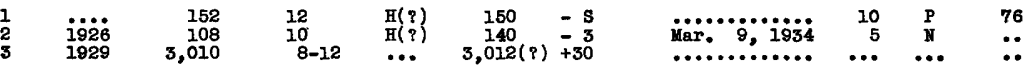

Broward County

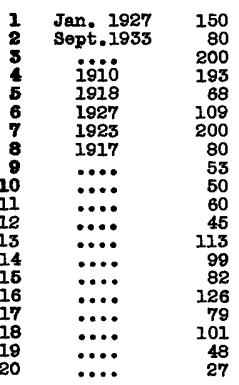

Citrus County

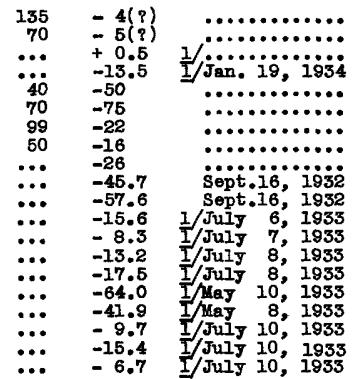

$\begin{array}{lcc}5(?) & P & 76 \\ 5(?) & \text { Ind. } & \because \\ 22 & \text { Ind. } & \because \\ 26 & \mathrm{D} & \because \\ 60 & \cdots & 73 \\ 95 & \mathrm{~S} & 74 \\ 62 & \mathrm{P} & \because \\ 50 & \mathrm{D} & \because \\ 47.9 & \cdots & \because \\ 60.1 & \cdots & \because \\ 63.7 & \cdots & \because \\ 32.9 & \cdots & \because \\ 38.2 & \cdots & \because \\ 47.7 & \cdots & \because \\ 44.5 & \cdots & \because \\ 70.5 & \cdots & \because \\ 58.0 & \cdots & \cdots \\ 20.7 & \cdots & \cdots \\ 32.2 & \cdots & \cdots \\ 11.6 & \cdots & \cdots\end{array}$

Clay County

$\begin{array}{lll}1 & 1930 & 580 \\ 2 & 1897 & 450 \\ 3 & 1912 & 450 \\ 4 & 1910 & 530 \\ 5 & 1907 & 330 \\ 6 & 1925 & 414 \\ 7 & 1907 & 498 \\ 8 & 1907 & 360 \\ 9 & 1927 & 419 \\ 10 & 1909 & 450 \\ 11 & 1909 & 500 \\ 18 & 1971934 & 400 \\ 13 & 1890(9) & 600 \\ 14 & 1927 & 850 \\ 15 & 1929 & 680 \\ 16 & \cdots 1 . & 400+ \\ 17 & 1938 & 400+ \\ 18 & 1928 & 500+ \\ 19 & 1928 & 550 \\ 20 & 1929 & 420 \\ 21 & 1926 & 600 \\ 22 & 1926 & 600 \\ 23 & 1920 & 360+ \\ 24 & 1917 & 329\end{array}$

4.5
3
4
6
3
8
3
3
6
4
4
6
4
8
6
5
6
8
8
8
6
6
6
4

$\begin{array}{ll}300 & -6.5 \\ 300 & +39 .+ \\ 300 & +45 \\ 350 & +44 \\ 300 & +25 \\ 100 & +45 \\ 300 & +45 \\ 330 & +17 .+ \\ 36 & +40 \\ 80 & +41 \\ 137 & +41 \\ 72 & +41.5 \\ 150(?) & +18.0 \\ 400 & +1.5 \\ 420 & -75.2 \\ 400 & -10.2 \\ 350+ & -4.95 \\ 250 & -9.0 \\ 260 & -18 \\ 220 & -20.2 \\ 200 & +28 \\ 200 & +21.5 \\ 80 & +34 \\ 50+ & +30\end{array}$

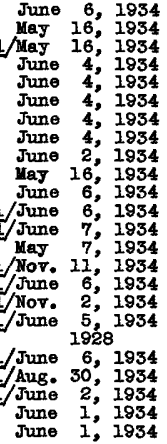

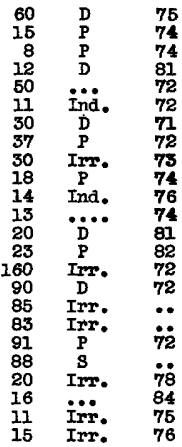

Coll1er County

$\begin{array}{lllll}1 & 1910 & 590 & 6 & \text { H } \\ 2 & 1925 & 42 & 2 & \cdots \\ 3 & \cdots \ldots . & 400 & 6 & \text { H } \\ 4 & \because \cdots 3 & 500 & 3.5 & \text { H } \\ 5 & \text { Aprii } 1924 & 432 & 6 & \text { H } \\ 6 & \text { JulJ } 1929 & 426 & 6 & \text { H } \\ 7 & \text { Sept. } 1925 & 565 & 4 & \text { H }\end{array}$

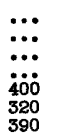

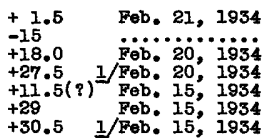

Columbia County

$\begin{array}{lcrrr}1 & \text { March } 1934 & 325 & \\ 2 & 1905 & 420 & \\ 3 & \dddot{0} & 65 & \\ 4 & 1931 & 152 & \\ 5 & \ldots \cdots & 70 & \\ 6 & \cdots \cdots & 70 & \\ 7 & \cdots \cdots & 100 & \\ 8 & \cdots \cdots & 165 & \end{array}$

1 Jan. $1934 \quad 977$

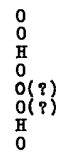

Charlotte County

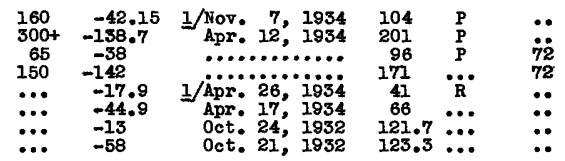

Dade County

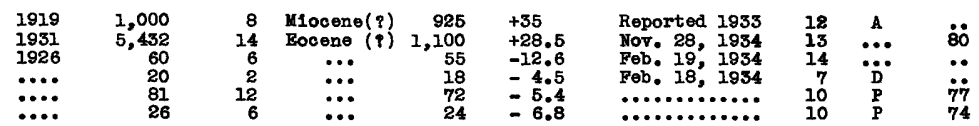

$1 /$ Alsc measured on other dates; see table of well messurements. 
Records of wells in the Florida peninsula - Contimed

\begin{tabular}{|c|c|c|c|c|c|c|c|c|c|c|}
\hline \multirow{2}{*}{ Ho. } & \multirow{2}{*}{$\begin{array}{c}\text { Date } \\
\text { cons- } \\
\text { pleted }\end{array}$} & \multirow{2}{*}{$\begin{array}{l}\text { Depth } \\
\text { (feet) }\end{array}$} & \multirow{2}{*}{$\begin{array}{l}\text { Diameter } \\
\text { (inches) }\end{array}$} & \multirow{2}{*}{ Source } & \multirow{2}{*}{$\begin{array}{l}\text { Depth of } \\
\text { casing } \\
\text { (feet) }\end{array}$} & \multicolumn{2}{|c|}{ Water level } & \multirow{2}{*}{$\underset{\text { (feet) }}{\text { M. }}$} & \multirow{2}{*}{ Use } & \multirow{2}{*}{$\begin{array}{l}\text { Iemper } \\
\text { ature } \\
\left({ }^{\circ} \mathrm{F} .\right)\end{array}$} \\
\hline & & & & & & Feet & Date & & & \\
\hline
\end{tabular}

De Soto County

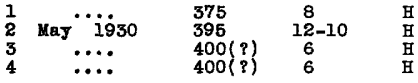

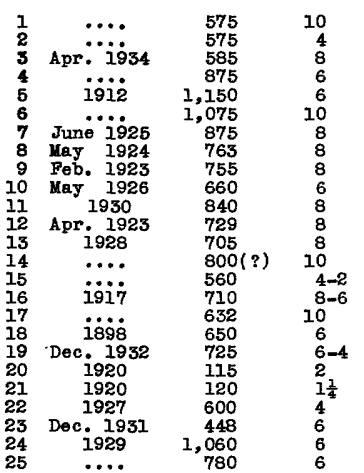

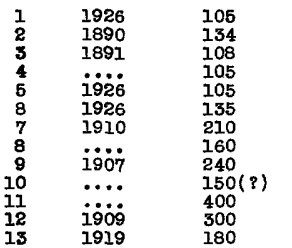

$\begin{array}{lll}1 & 1928 & 115 \\ 2 & \ldots \ldots & 300(?) \\ 3 & \ldots \ldots & 47 \\ 4 & \ldots \ldots & 40 \\ 5 & \cdots \cdots & 63 \\ 6 & 1928 & 110 \\ 7 & 1928 & 175\end{array}$

$\begin{array}{llll}1 & \cdots & 525 & 6\end{array}$

$\begin{array}{lccr}1 & 1913 & 308 & \\ 2 & \text { Aug. } 1932 & 345 & 8 \\ 3 & 1926 & 625 & 303\end{array}$

\begin{tabular}{l}
$\mathrm{H}, 0$ \\
$\mathrm{H}, 0$ \\
$\mathrm{H}, 0$ \\
0 \\
0 \\
0 \\
0 \\
0 \\
0 \\
0 \\
0 \\
0 \\
0 \\
0 \\
0 \\
0 \\
0 \\
0 \\
0 \\
$\mathrm{H}$ \\
\hdashline \\
0 \\
0 \\
0 \\
0
\end{tabular}

$$
\begin{array}{ll}
327 & -8.63 \\
\cdots & +22 \\
\cdots & +21.5
\end{array}
$$

Jan. 24, 1934 Jan. 27, 1934 Jan. 27, 1934

Duval County

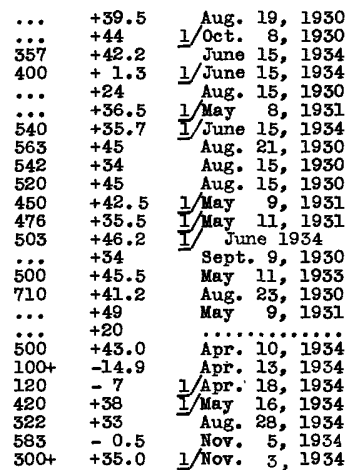
$\begin{array}{lll}59 & \mathrm{~N} & \\ 32 & \mathrm{P} & 80 \\ 50(8) & \mathrm{N} & 79 \\ 75 & \mathrm{~N} & \cdots\end{array}$

gler county

$\begin{array}{ll}102 & +9 \\ 130 & +12 \\ 108 & +15 \\ 105 & +15 \\ 100 & +13 \\ 120 & +13 \\ 100+ & +0.5 \\ 100 & +2.0 \\ 120 & +0.5 \\ \cdots & +5 \\ 130 & +7.5 \\ 130 & -2.0 \\ \cdots & -8.0\end{array}$

June 25,1934
June 25,1934
June $25, \ldots 1934$
June 25,1934
June 25,1934
June 28,1934
June 28,1934
June 28,1934
May 25,1934
May 25,1934
$\ldots \ldots \ldots \ldots$

G1lchrist County

0
0
$\cdots$
$\cdots$
$\cdots$

$$
\begin{array}{ll}
35 & -21.4 \\
150(?) & -42.5 \\
\cdots . . & -40.3 \\
\cdots & -32 \\
\cdots \cdots & -55 \\
i 00+ & -50 \\
-12.2
\end{array}
$$

Apr. 25, 1934 1/Apr. 25, 1934 Dec. 16, 1934 Dec. 16, 1954 Sept. 1, 1934 Dec. 20,1934
Nov. 17,1934

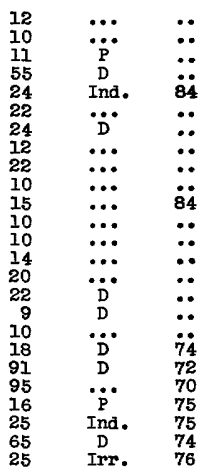

\begin{tabular}{|c|c|}
\hline $\begin{array}{l}14 \\
14\end{array}$ & $\underset{\mathbb{N}}{\text { Ind. }}$ \\
\hline 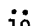 & $\cdots$ \\
\hline $\begin{array}{r}10 \\
8\end{array}$ & 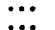 \\
\hline$\theta$ & ... \\
\hline 28 & $\ldots$ \\
\hline 26 & •. \\
\hline 28 & $\cdots$ \\
\hline 10 & $\cdots$ \\
\hline 23 & \\
\hline & \\
\hline
\end{tabular}

Glades county

$$
\underset{\mathrm{H}, \mathrm{T}}{\mathrm{H}}
$$

$\ddot{700}+\ldots$

May 8,1933

Hamilton County

$\begin{array}{ll}138 & -84 \\ 110 & -104 \\ 500+ & -112 \\ 205 & -76.88\end{array}$
.............. 140

$\begin{array}{lll}42 & \text { P } & 73 \\ 63 & \ldots & \ldots \\ 49.6 & \ldots & \ldots \\ 40.8 & \ldots & \ldots \\ 67.2 & \ldots & \ldots \\ 92.1 & \ldots & \ldots \\ 22 & \mathrm{R} & \ldots\end{array}$

Hardee County

$\begin{array}{lll}\mathbf{1} & \text { i9i4(?) } & 800 \\ \mathbf{s} & 1914 & 730\end{array}$

$\begin{array}{llll}1 & \text { igii } & 600 & 3 \\ 2 & 640 & 6\end{array}$

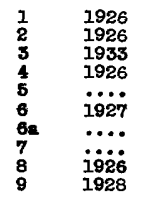

$\begin{array}{lcc}200 & 8 & 0 \\ 200 & 8 & 0 \\ 804 & 10 & 0 \\ 200(?) & 18 & 0 \\ 225 & 2 & 0 \\ 103 & 2 & 0 \\ 46 & 2 & \cdots \\ 30 & 1.5 & \cdots \\ 260 & 5 & T, 0 \\ 602 & 18 & 0\end{array}$

Feb. 21, 1934

Feb. 21, 1934
Feb. 16, 1934
$\ldots \ldots \ldots \ldots \ldots$

$\cdots \quad+10$

Hendry County

$\cdots \quad+15$

$\begin{array}{rrrr}\text { Feb. 21, } 1934 & 25 & \text { Irr. } & 77 \\ 1 \text { Feb. } 2,1934 & 18 & \mathrm{P} & 81\end{array}$

Hernando County

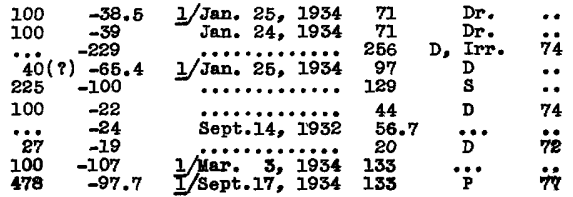

1 Alsc measured on other dates; see table of well measurements. 
Records of wells in the Florida peningula - Continued

\begin{tabular}{|c|c|c|c|c|c|c|c|c|c|c|}
\hline \multirow{2}{*}{ No. } & \multirow{2}{*}{$\begin{array}{c}\text { Date } \\
\text { com- } \\
\text { pleted }\end{array}$} & \multirow{2}{*}{$\begin{array}{l}\text { Depth } \\
\text { (feet) }\end{array}$} & \multirow{2}{*}{$\begin{array}{l}\text { Diameter } \\
\text { (1nches) }\end{array}$} & \multirow{2}{*}{ Source } & \multirow{2}{*}{$\begin{array}{l}\text { Depth of } \\
\text { casing } \\
\text { (feet) }\end{array}$} & \multicolumn{2}{|c|}{ Water level } & \multirow{2}{*}{$\begin{array}{c}\text { M. } \\
\text { (feet) }\end{array}$} & \multirow{2}{*}{ ปse } & \multirow{2}{*}{$\begin{array}{l}\text { Temper } \\
\text { ature } \\
\text { (o.) }\end{array}$} \\
\hline & & & & & & Feet & Date & & & \\
\hline \multicolumn{11}{|c|}{ Hernando County - Continued } \\
\hline $\begin{array}{l}10 \\
11 \\
12 \\
13 \\
14 \\
15 \\
16 \\
17\end{array}$ & $\begin{array}{l}1917 \\
1927 \\
1927 \\
\ddot{192 i} \\
\ddot{1920} \\
\ldots \ldots\end{array}$ & $\begin{array}{c}213 \\
205 \\
190 \\
74 \\
984 \\
200+ \\
114 \\
74\end{array}$ & $\begin{array}{r}8 \\
10 \\
10 \\
2 \\
10 \\
6 \\
6 \\
6\end{array}$ & $\begin{array}{c}0 \\
0 \\
0 \\
0 \\
0 \\
0 \\
\mathrm{~T}, 0 \\
\cdots\end{array}$ & $\begin{array}{r}125 \\
100 \\
100 \\
74 \\
100 \\
\cdots 0 \\
\ldots 0\end{array}$ & $\begin{array}{l}-100 \\
-5 \\
-5 \\
-21 \\
-45 \\
-15.8 \\
-79 \\
-20.6\end{array}$ & 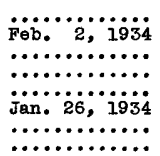 & $\begin{array}{c}133 \\
47 \\
47 \\
54 \\
79 \\
72 \\
105 \\
56.6\end{array}$ & $\begin{array}{l}\text { Ind. } \\
\text { Ind. } \\
\text { Dom. } \\
\text { Dom. } \\
\text { P. } \\
\text {... }\end{array}$ & 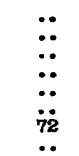 \\
\hline
\end{tabular}

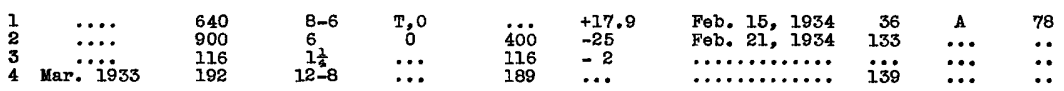

Hillsborough county

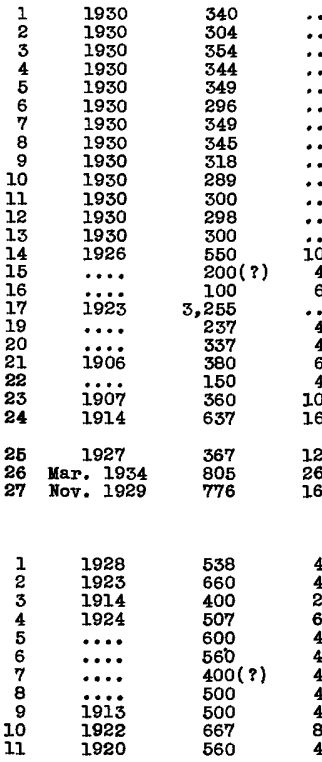

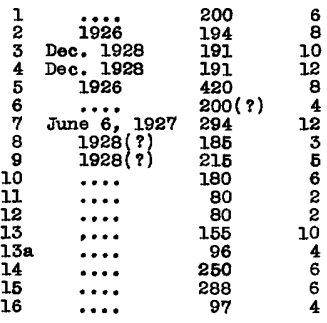

$T$
$T$
$T$
$T$
$T$
$T$
$T, 0$
$T, 0$
$T$
$T$
$T$
$T$
$T$
$T$
$T$
$T$
Eocene( $P)$
$T, 0$
$T, 0$
$T, 0$
$T, 0$
$T, 0$
$T, 0$
$T, 0$
0

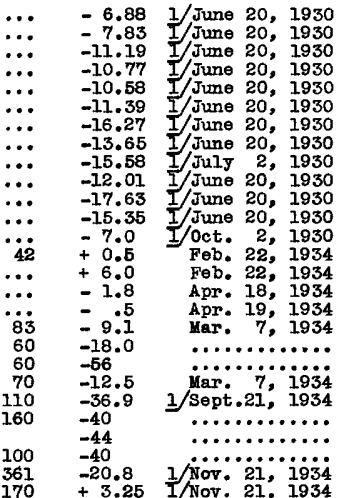

Indian River County

$\begin{array}{ccl}0 & 190 & +24 \\ 0 & 150 & +27.7 \\ 0 & 200 & +29.5 \\ 0 & 180 & +36 \\ 0 & 320 & +20 .+ \\ 0 & 140 & +17.7 \\ \cdots 0 & \cdots & +6.5 \\ 0 & \cdots \cdots & +21 \\ 0 & \cdots \cdots & +23 \\ 0 & \cdots & +35 \\ & \cdots & +33\end{array}$

Aug. 14, 1934

Aug. 14, 1934

Aug. 14, 1934

1924

Feb. 13, 1934

Feb. 13, 1934

Feb. 13, 1934

..............

กัov. $\ddot{2} \ddot{9} \ddot{1934}$

Lake County

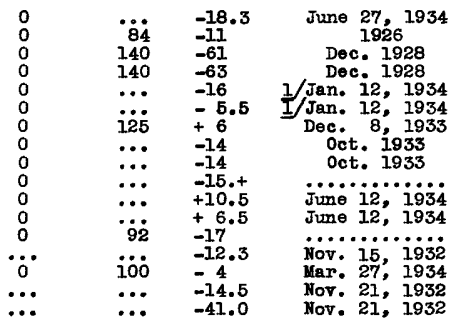

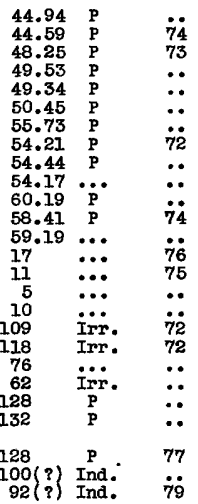

$\begin{array}{lcc}31 & \text { Irr. } & 79 \\ 28 & \text { Irr., Ind. } 79 \\ 16 & \text { D } & 80 \\ 15 & \text { Ind. } & 80 \\ 25(?) & \mathrm{D} & 78 \\ 30 & \text { Irr. } & 77 \\ 16 & \mathrm{~A} & 74 \\ 30 & \mathrm{D} & \cdots \\ 30 & \mathrm{P} & \cdots \\ \ldots & \mathrm{P} & \because 7 \\ \ldots & \text { Irr. } & 77\end{array}$

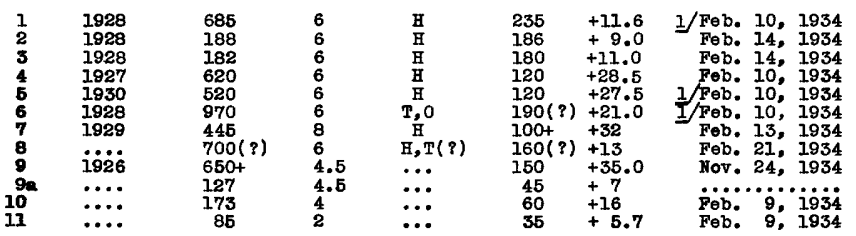

$\begin{array}{rll}5 & \text { Ind. } & 82 \\ 8 & \text { D } & 75 \\ 7 & \text { D } & 74 \\ 10 & \text { Irr. } & 82 \\ 9 & \text { Irr. } & 82 \\ 14 & \text { Irr. } & 86 \\ 1 I & \text { A } & 83 \\ 37 & \text { Ind. } & 86 \\ 9 & \text { P } & 82 \\ 7 & \text { D } & 10 \\ 9 & \text { Irr. } & 76 \\ 9 & \text { D } & 73\end{array}$

1 Also measured on other dates; see table of well measurements. 
Records of wells in the Floride peninsule - Continued

\begin{tabular}{|c|c|c|c|c|c|c|c|c|c|c|}
\hline \multirow{2}{*}{ No. } & \multirow{2}{*}{$\begin{array}{c}\text { Date } \\
\text { com- } \\
\text { pleted }\end{array}$} & \multirow{2}{*}{$\begin{array}{l}\text { Depth } \\
\text { (feet) }\end{array}$} & \multirow{2}{*}{$\begin{array}{l}\text { Diameter } \\
\text { (1nches) }\end{array}$} & \multirow{2}{*}{ Source } & \multirow{2}{*}{$\begin{array}{l}\text { Depth of } \\
\text { casing } \\
\text { (feet) }\end{array}$} & \multicolumn{2}{|c|}{ Water level } & \multirow{2}{*}{ M. P. } & \multirow{2}{*}{ Use } & \multirow{2}{*}{$\begin{array}{r}\text { Temper } \\
\text { ature } \\
\text { (op.) }\end{array}$} \\
\hline & & & & & & Fe日t & Date & & & \\
\hline
\end{tabular}

Lee County - Continued

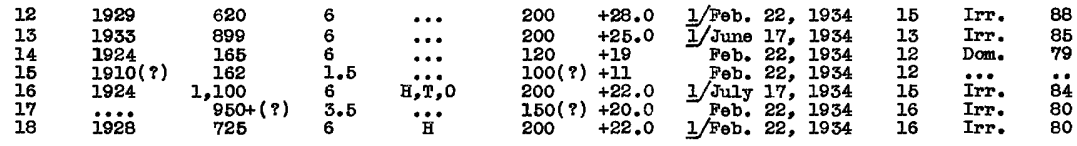

$\begin{array}{rcr}1 & \text { Jan. } 1927 & 717 \\ 2 & 1923 & 190 \\ 3 & 1930 & 75 \\ 4 & 1928 & 1,115 \\ 5 & \cdots \cdots & 97 \\ 6 & \cdots \cdots & 105 \\ 7 & \cdots \cdots & 36 \\ 8 & \cdots \cdots & 21 \\ 9 & \cdots \cdots & 16 \\ 10 & \cdots \cdots & 36 \\ 11 & \cdots \cdots & 32 \\ 12 & \cdots \cdots & 98 \\ 13 & \cdots \cdots & 125 \\ 14 & \cdots \cdots & 10 \\ 15 & \cdots \cdots & 75 \\ 16 & \cdots \cdots & 124 \\ 17 & \cdots \cdots & 70 \\ 18 & \cdots \cdots & 40 \\ 19 & \cdots \cdots & 38 \\ 20 & \cdots \cdots & 54 \\ 21 & \cdots \cdots & 101 \\ 22 & \cdots \cdots & 15\end{array}$

Lovy county

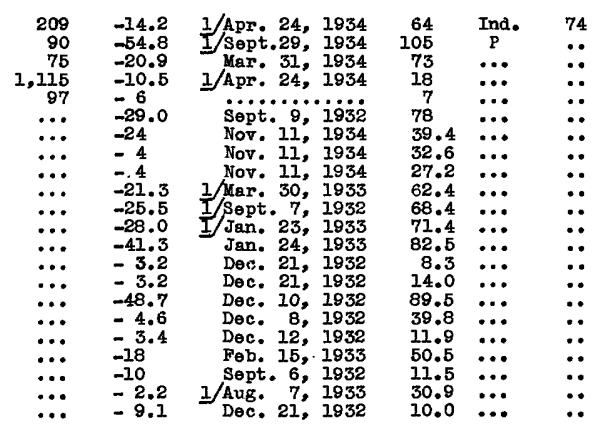

Manatee County

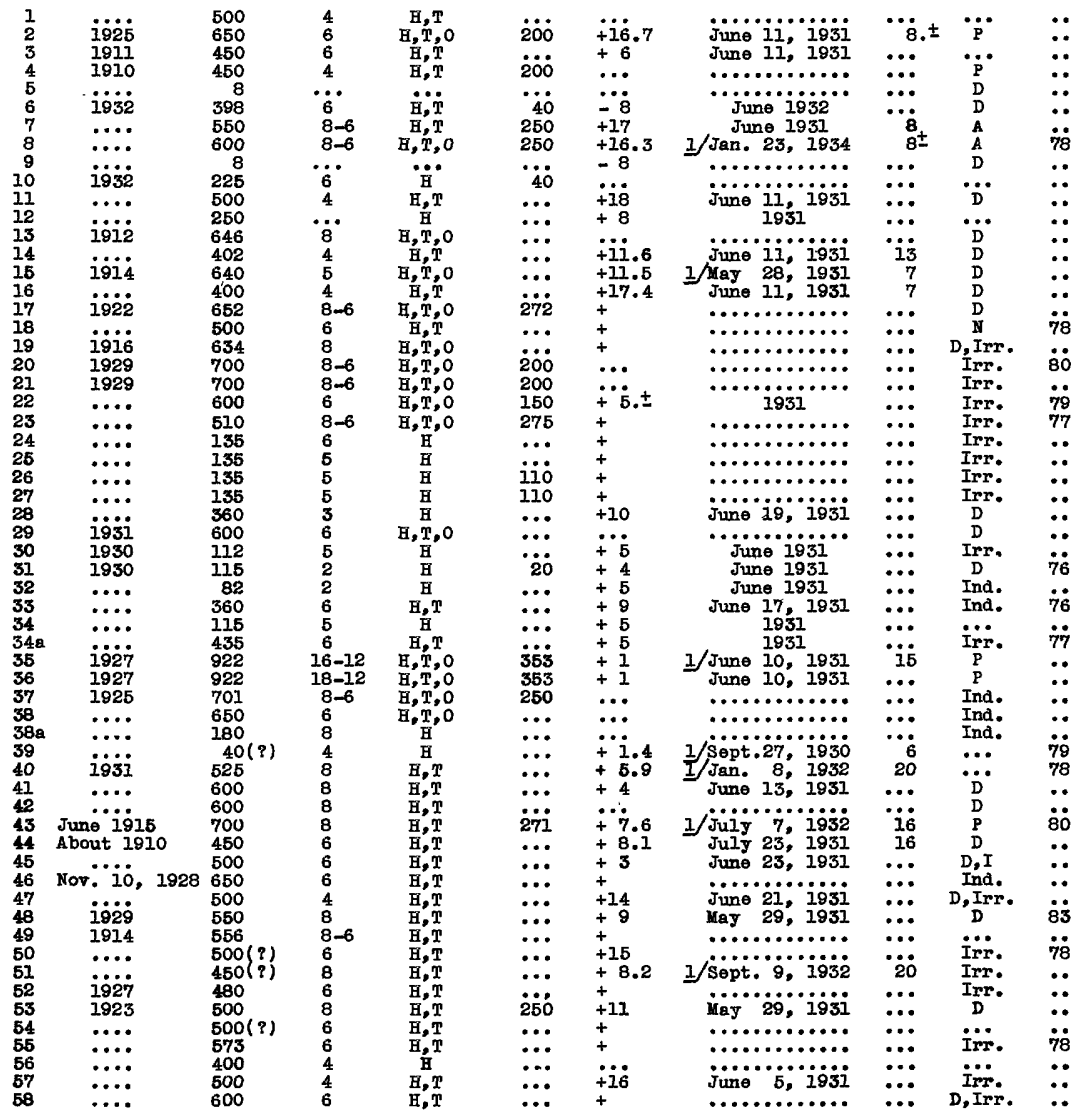


Records of weils in the Florida peninsula - Continued

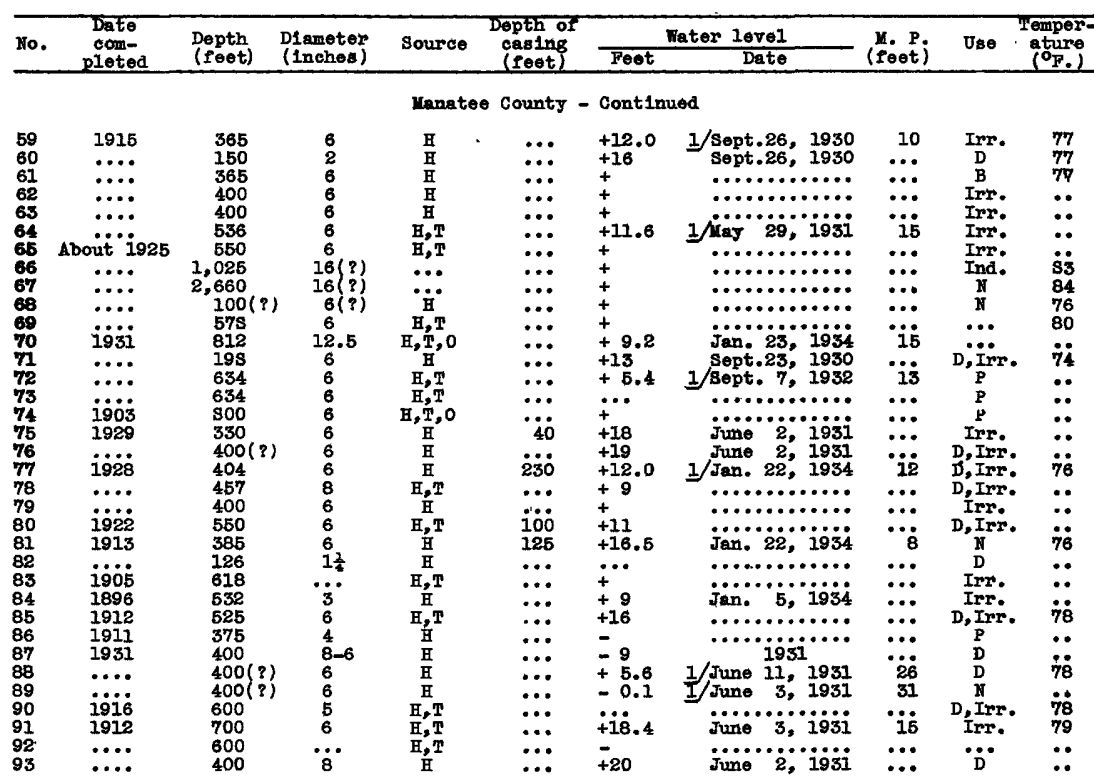

Marton County

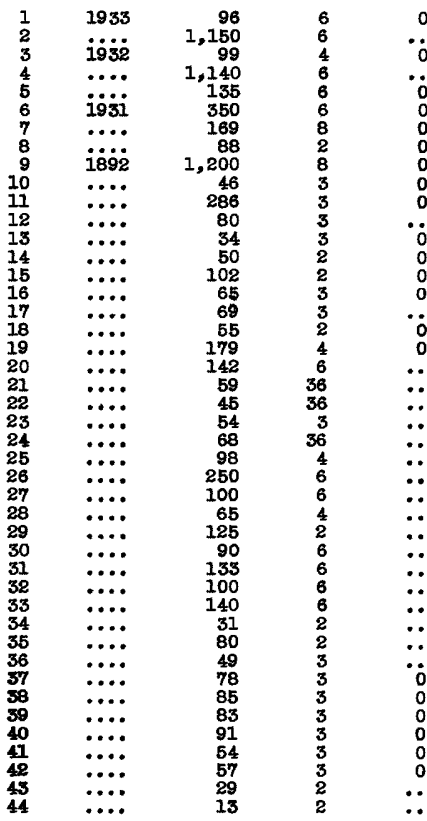

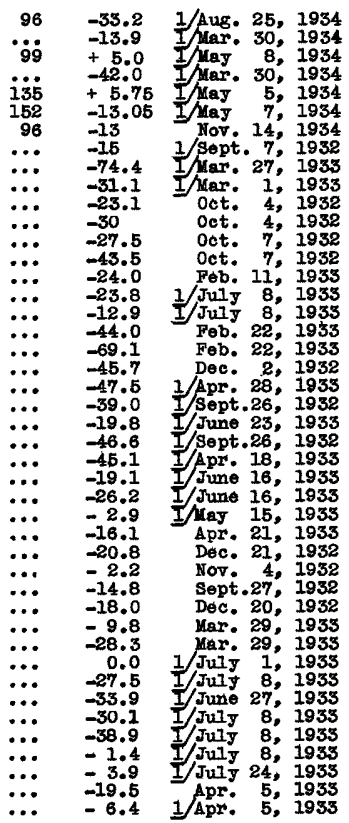

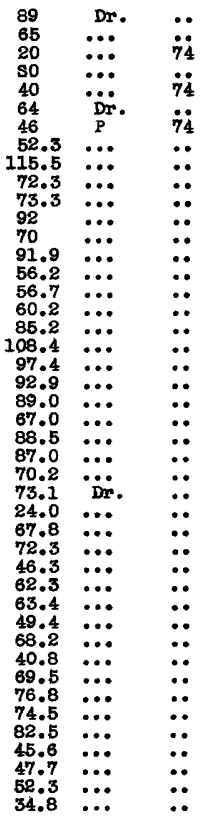

\section{Martin County}

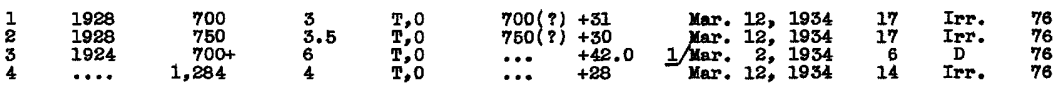

\section{Monroe county}

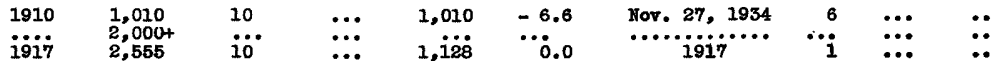
1 Also measured on other dates; see table of well measurements. 
Records of wells in the Florids peningula - Continued

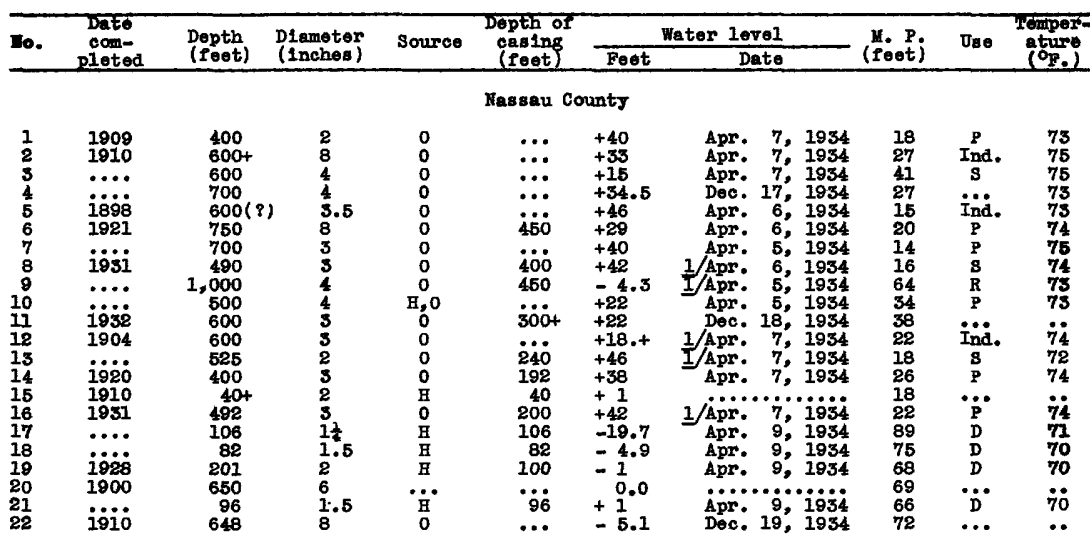

Okeechobee county

1

$718 \quad 8-6$

$484+18$

1/Feb. 15, 1934

32

79

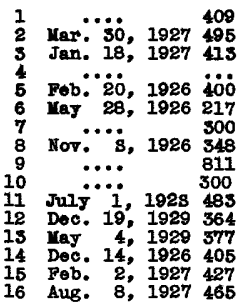

Orange oounty

$$
130 \quad-28.4 \quad 1 / \text { June } 19,1934
$$

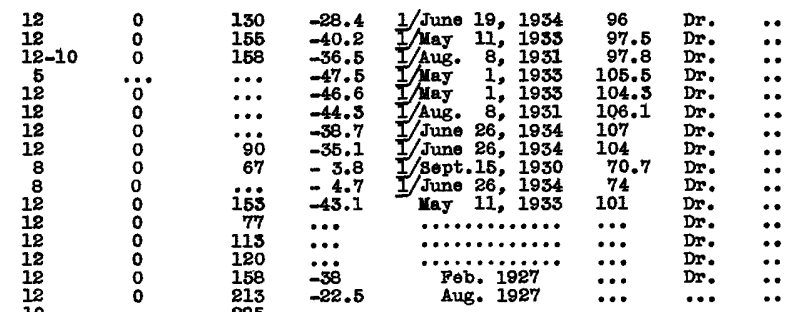

17 Sept. 1, 1926430

18 Jay 6,1926353

20 Apr. $\ddot{2}, 1926 \begin{aligned} & 865 \\ & 313\end{aligned}$

21 0ot. 18, 1926 213

22 0ct. 19, 1926183

23 0ct. 2, 1926228

24 Oct. 1, 1926408

26 Mar: $\ddot{2} \dot{s}, 1926219$

28 July 8, 1926469

30 Mar. ”i⿱宀, 1926408

31 Fob. 15, 1927451

32 Feb. “4, 1927439

34 Nov. 12, 1926454

35 Det. $1927 \quad 160$

160
457

$\begin{array}{lll}6 & 110 \% \cdot 1927 & 457 \\ 7 & 197.1927 & 375\end{array}$

Hov. 7, 1927141

Dec. 29, 1927 417

40
41
Jec. 15,1928

42 Apr. 1928

390

Apr. 1928
June 1928

June 1928

July 1928

Aug. 1928

Aug. 1928

Bept.1928

No7. 1928

Dec. 1928

ï̈во

oct. 1928

427
463
452

452
422

328

125
485

383

\begin{tabular}{rr}
199 & 16 \\
\hline
\end{tabular}

$1930 \quad 400(?)$

400 (?) 12

56 Apr. 5, 1926 425

1 Also measured on other dates; seo table of well measurements. 
Becords of wells in the Florlda peninsula - Continued

\begin{tabular}{|c|c|c|c|c|c|c|c|c|c|c|}
\hline \multirow{2}{*}{ Ho. } & \multirow{2}{*}{$\begin{array}{l}\text { Date } \\
\text { com- } \\
\text { pleted }\end{array}$} & \multirow{2}{*}{$\begin{array}{l}\text { Depth } \\
\text { (feet) }\end{array}$} & \multirow{2}{*}{$\begin{array}{l}\text { Dlameter } \\
\text { (Inches) }\end{array}$} & \multirow{2}{*}{ Source } & \multirow{2}{*}{$\begin{array}{l}\text { Depth of } \\
\text { casing } \\
\text { (feet) }\end{array}$} & \multicolumn{2}{|c|}{ Water Ievel } & \multirow{2}{*}{ (feot) } & \multirow{2}{*}{ Use } & \multirow{2}{*}{$\begin{array}{l}\text { remper- } \\
\text { ature } \\
\text { (OF.) }\end{array}$} \\
\hline & & & & & & Feet & Date & & & \\
\hline
\end{tabular}

$\begin{array}{llll}58 & \ldots \ldots & 130 & 4 \\ 59 & \cdots \cdots 2 & 300 & 4 \\ 60 & 1925 & 500 & 16 \\ 61 & \ldots \ldots & 500(?) & 8 \\ 62 & \cdots \cdots & 484 & 12-10 \\ 63 & \cdots \cdots & 300(?) & 10 \\ 64 & \ldots 3 & 300(?) & 10 \\ 65 & 1926 & 211 & 10 \\ 66 & \ldots \ldots & 200(?) & 4\end{array}$

\section{Orange County - Contimued}

$\begin{array}{ll}1 & 193 \\ 2 & 1927 \\ 3 & 191 \\ 4 & 191 \\ 5 & 191 \\ 6 & 191 \\ 7 & 192 \\ 8 & 1924\end{array}$

$\begin{array}{rlr}1932 & 90 & 4 \\ 1927 & 475 & 6 \\ 1910 & 400(?) & 4 \\ 1910 & 350 & 8 \\ 1916 & 450 & 12 \\ 1925 & 729 & 8 \\ 1924 & 602 & 10 \\ & 600 & 6\end{array}$

$\begin{array}{rrr}1 & 133 \dot{2} & 60 \\ 2 & 192 \\ 3 & 1930 & 180 \\ 4 & 1926 & 1,050 \\ 5 & 1933 & 85 \\ 6 & 1926 & 135 \\ 7 & 1934 & 135 \\ 8 & 1934 & 202 \\ 9 & 1924 & 100 \\ 10 & 1926 & 1,332 \\ 11 & \ldots \ldots & 958\end{array}$
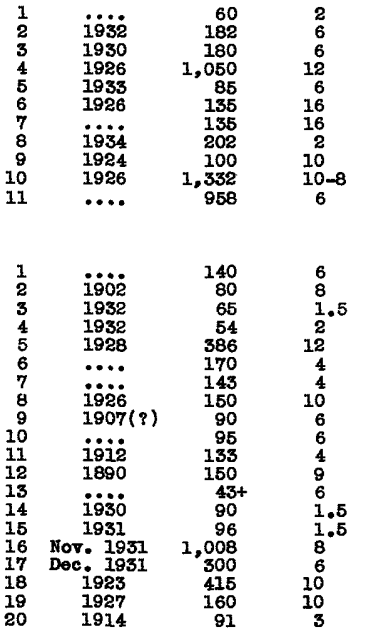

$\begin{array}{lrr}1 & \text { Dec. 20, } 1922 & 166 \\ 2 & \ldots \ldots & 186 \\ 3 & \ldots \ldots & 207 \\ 4 & \ldots \ldots & 200 \\ 5 & \ldots \ldots & 192 \\ 6 & \ldots \ldots & 195 \\ 7 & \ldots \ldots & 195\end{array}$

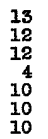

$\begin{array}{lcr}1 & \text { sept. } 1932 & 578 \\ 2 & 1925 & 567 \\ 3 & 1932 & 400 \\ 4 & 1932 & 365 \\ 5 & 1924 & 365 \\ 6 & \text { June } 1926 & 490 \\ 7 & \text { June } 1926 & 680 \\ 8 & \cdots & 476 \\ 9 & 1921 & 753 \\ 10 & 1924 & 360 \\ 11 & 1910 & 804 \\ 12 & 1922 & 747 \\ 13 & \cdots \ldots . . & 1,201 \\ 14 & 1936 & 490 \\ 15 & 1926 & 155 \\ 16 & 1924 & 157 \\ 17 & 1928 & 245 \\ 18 & 1928 & 195 \\ 19 & 1917 & 495 \\ 20 & 1916 & 613 \\ 21 & 1928 & 404 \\ 22 & 1921 & 600 \\ 23 & \cdots \cdots & 400 \\ 24 & \ldots \ldots & 700\end{array}$

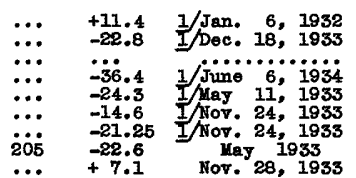

$206+22.6$

Osceola County

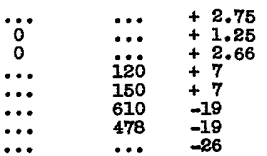

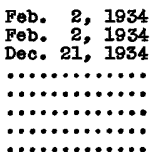

$\begin{array}{lll}76 & \ldots & 74 \\ 72 & \AA & 75 \\ 70 & 1 \% 2 & 74 \\ 65 & \ldots & \because \\ 65 & \ldots & \because \\ 81(?) & \cdots & \because \\ 81(?) & \cdots & \because \\ 80 & \ldots & \ldots\end{array}$

Palm Beach County

$\begin{array}{rrl}\ldots & 60 & -6 \\ \because . & 182 & -16 \\ \because 0 & 180 & -13 \\ \cdots & 1,050 & +19.25 \\ \cdots & 85 & -3 \\ \cdots & 135 & -17 \\ \cdots & 135 & -19 \\ \because \cdots & 202 & -2 \\ 0 & 100 & -10 \\ T, 0 & 957 & +35 \\ & 850 & +32\end{array}$

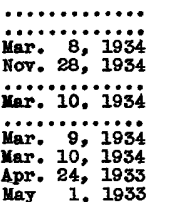

$\begin{array}{ccc}74.4 & \operatorname{Irr} . & \ldots \\ 107 & \operatorname{Irr} ., D r . & \ldots \\ 123.4 & \text { Irr.,Dr. } & \ldots \\ 101.4 & \mathrm{Dr} . & \ldots \\ 81.6 & \mathrm{Dr} . & \ldots \\ 87 & \mathrm{Dr} . & \ldots \\ 69 & \mathrm{Dr} . & \ldots \\ 35 & \mathrm{Irr} . & 72\end{array}$

Pasco County

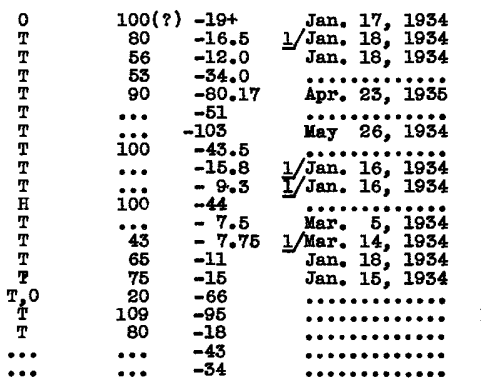

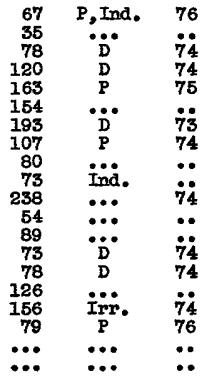

Pinellas County

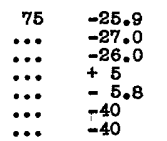

Apr. 8,1933
Apr. $8 ; 1933$
Apr. 8, 1933
Apr. 19, 1934
Sept.12, 1930
$\ldots \ldots \ldots \ldots \ldots$

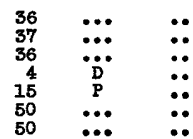

Polk County

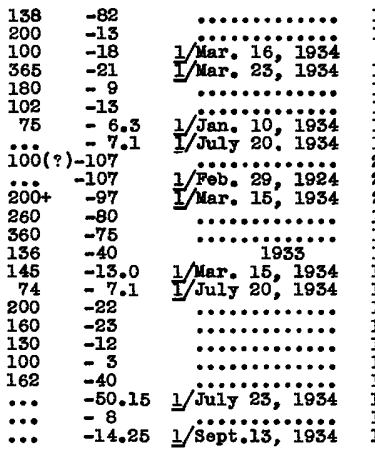

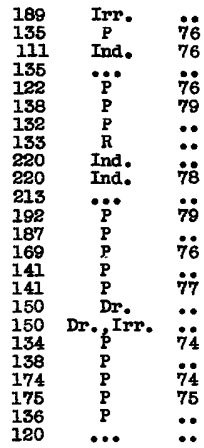

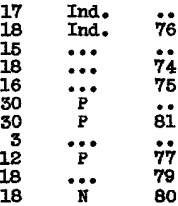

6

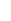
$\because$ $\because$ 政 
Records of wells in the Florida peninsula - Contimued

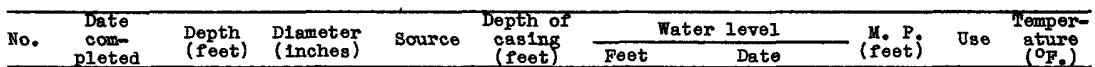

Polk County - Continued

\begin{tabular}{|c|c|c|}
\hline $\begin{array}{l}25 \\
26 \\
27 \\
28 \\
29 \\
30 \\
31 \\
32 \\
33 \\
34 \\
35 \\
36 \\
37 \\
38 \\
39 \\
40 \\
41\end{array}$ & 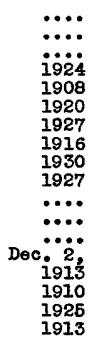 & 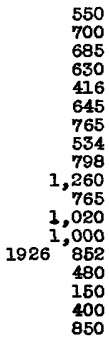 \\
\hline
\end{tabular}

10
10
10
6
8
18
15
12
15
12
30
15
18
$30-18$
6
6
8
12

0
0
0
0
0
0
0
0
0
0
0
0
0
0
0
H,T
T, 0
0

$\cdots$
30
416
645
700
140
98
1,100
351
480
500
324
200
30
160
800

-17.9
-14.7
-29.5
-33.4
-16
-28.7
-20
$=6.15$
$=2.45$
-2.3
-62.77
-47.0
-42.8
-49.8
+11.2
+4.2
+1.1
-42

Putnam County

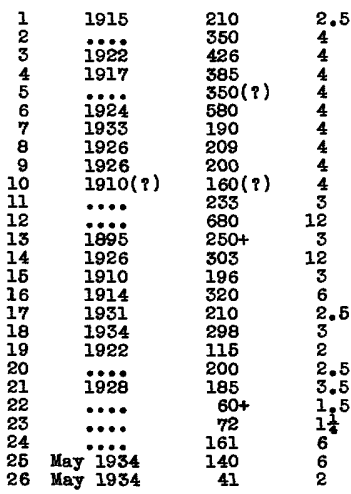

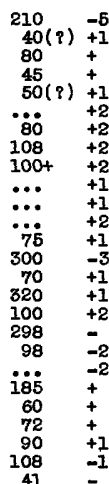

-50
+17
+7
+9
+10
+23
+22
+24
+23
$+12 .+$
+16
+20
+15
-34.3
+19
+10.5
+26
+5.5
-22
-20.8
+8
+3
+5
+16
+12.3
-9.7

June May 37, 1934 May 31,1934 May 31, 1934 May 31,1934 May 11,1934 Мay 11, 1934 May 11, 1934 May 11,1934 Hay 11, 1934 1 /May 8, 1934 May 8,1934 $1 /$ Apr. 22, 1934 May 11, 1934 June 9, 1934 Hay 11,1934 May 24, 1934 May 10, 1934 $\begin{array}{lll}\text { May 9, } & 1934 \\ \text { May } & 9,1934\end{array}$ мay $\ddot{9} \ddot{1934}$ ….....”.... May 24, 1934

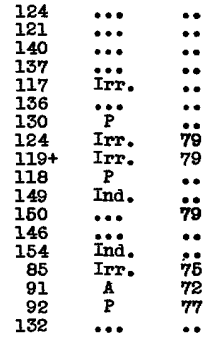

st. Johns County

$\begin{array}{rcl}1 & 1880 & 800 \\ 2 & 1928 & 640 \\ 3 & 1916 & 388 \\ 4 & 1925 & 336 \\ 5 & 1925 & 365 \\ 6 & 1912 & 490 \\ 7 & 1931 & 350 \\ 8 & \ldots \ldots & 300+ \\ 9 & 130 & 300+ \\ 10 & 1930 & 400+ \\ 11 & 1909 & 302 \\ 12 & \text { Aug. } 1931 & 410 \\ 13 & \text { June } 1933 & 421 \\ 14 & 1931 & 216 \\ 15 & 1933 & 198 \\ 16 & 1908 & 260 \\ 17 & 1923 & 245 \\ 18 & 1920 & 300 \\ 19 & 1926 & 196 \\ 20 & 0 c t .1933 & 235 \\ 21 & 1910 & 280 \\ 22 & 1933 & 222 \\ 23 & 1933 & 222 \\ 24 & 1922 & 400+ \\ 25 & \ldots \ldots & 180(?) \\ 26 & \ldots \ldots & 310 \\ 27 & \text { Fob. } 1887 & 1,400 \\ 28 & \ldots \ldots & 358\end{array}$

$\begin{array}{cc}8 & 0 \\ 6 & 0 \\ 6 & 0 \\ 6 & 0 \\ 6 & 0 \\ 6 & 0 \\ 6 & 0 \\ \cdots & 0 \\ \cdots & 0 \\ 6 & 0 \\ 6 & 0 \\ 6 & 0 \\ 6 & 0 \\ 4 & 0 \\ 6 & 0 \\ 6 & 0 \\ 4 & 0 \\ 6 & 0 \\ 4 & 0 \\ 8 & 0 \\ 6 & 0 \\ 3 & 0 \\ 3 & 0 \\ 6 & 0 \\ 4 & 0 \\ 8 & 0 \\ 12.9 & \because 0 \\ 8 & 0\end{array}$

$\begin{array}{ll}\because 60 & +21 \\ 100 & +28 \\ 240 & +26 \\ 182 & +36 \\ 300 & +35 \\ 180(?) & +43 \\ \cdots \cdots & +18 \\ 100 & +19.0 \\ 150 & +20.0 \\ 107 & +33 \\ 200 & +35 \\ 193 & +31 \\ 104 & +38.5 \\ 195 & +29.5 \\ 100(?) & +17 \\ 100(7) & +15 \\ i 15+ & +16 \\ 172 & +14 \\ 80 & +16 \\ 80 & +29 \\ 85 & +25 \\ \cdots & +22.0 \\ \cdots & +23.0 \\ i \cdots & +27.2 \\ 170 & +30.0 \\ \cdots & +20.2\end{array}$

Aug. 28, 1934

$\begin{array}{rcc}142 & \text { D } & 75 \\ 23 & \text { Irr. } & 73 \\ 35 & \text { Ind. } & 74 \\ 31 & \text { Irr. } & 73 \\ 30 & \text { Irr. } & 73 \\ 26 & \mathrm{~S} & 74 \\ 5 & \ldots \ldots . & 76 \\ 11 & \text { Irr. } & 76 \\ 11 & \text { Ird. } & 76 \\ 14 & \mathrm{D} & 72 \\ 17+ & \mathrm{D} & 74 \\ 13+ & \ldots . . & 75 \\ 19 & \mathrm{P} & 75 \\ 106 & \mathrm{P} & 72 \\ 12 & \mathrm{R} & 75 \\ 14 & \mathrm{D} & 72 \\ 9 & \mathrm{D} & 72 \\ 9 & \mathrm{D} & 72 \\ 56 & \mathrm{D} & 74 \\ 55 & \ldots . . & \cdots 2 \\ 6 & \mathrm{D} & 72 \\ 12 & \mathrm{D} & 72 \\ 9 & \mathrm{D} & 72 \\ 20 & \mathrm{P} & 74 \\ \ldots \ldots & \ldots . . & \cdots \\ \ldots \ldots & \ldots . . & \ldots\end{array}$

St. Lucle Gounty

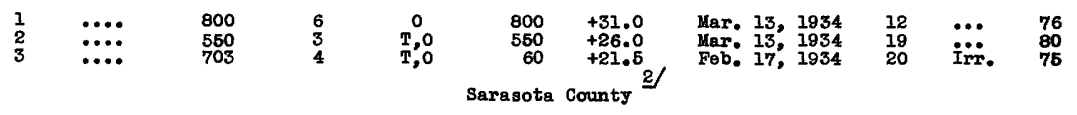

$\begin{array}{ccccccccccc}1 & 1924 & 675 & 8 & \mathrm{H}, \mathrm{T}, \mathrm{O} & 80 & +4.3 & 3 / \operatorname{Mar}, 11,1932 & 21.1 & P & \ldots \\ 2 & 1924 & 440 & 8 & \mathrm{H}, \mathrm{T} & \ldots & +11.6 & \underline{3} / \mathrm{Jun}, 24,1931 & 15.2 & \ldots & \ldots\end{array}$

1 Also messured on other dates; see table of well measurements.

23d - 2 Stringfield, V. T, Ground-water resources of Sarasota County: Florida Geol. Survey

3/ Also measured on other dates; see table 3 of Sarasota County report. 
Records of wells in the Florida peninsula - Contimued

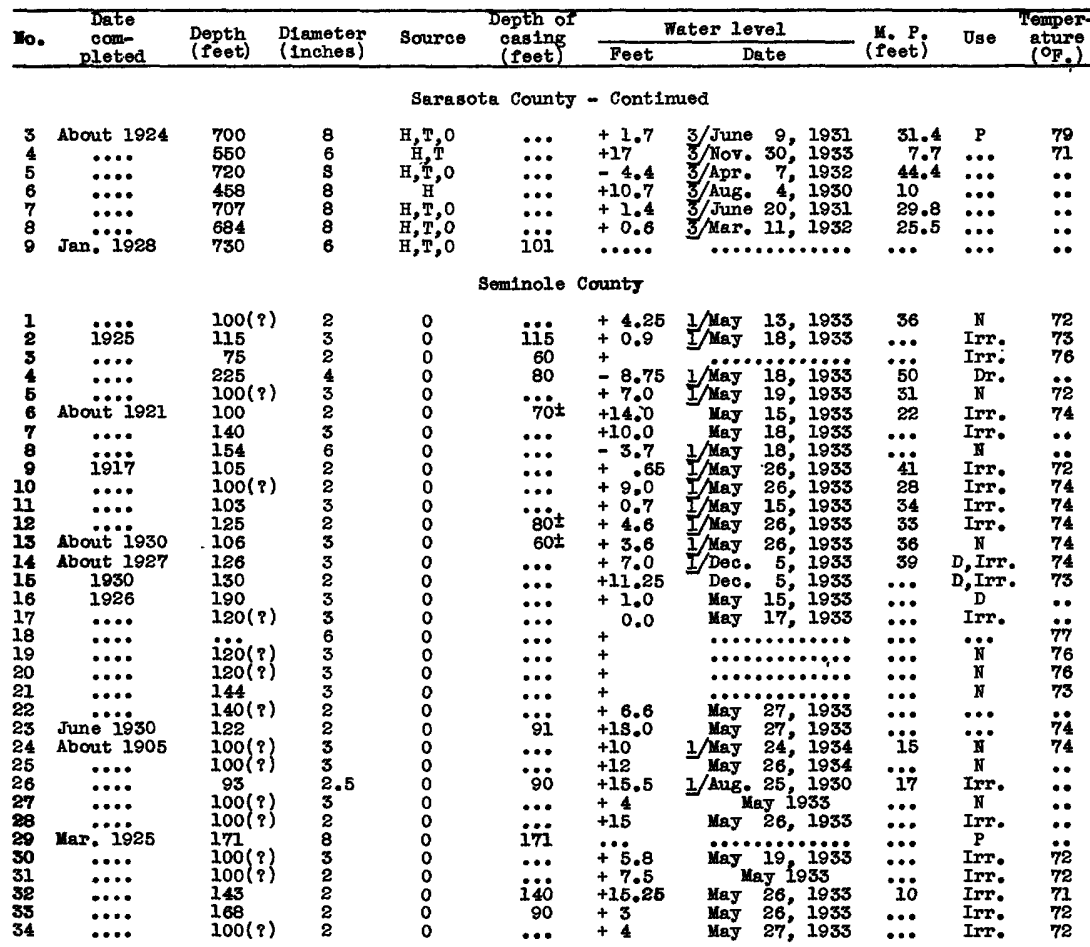

Sumter county

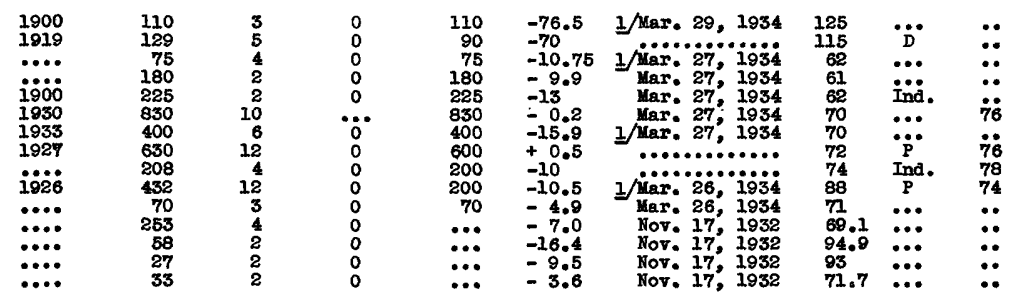

Suwannee County

\begin{tabular}{|c|c|c|c|}
\hline $\begin{array}{r}1 \\
2 \\
5 \\
4 \\
5 \\
6 \\
7 \\
8 \\
9 \\
10 \\
71 \\
12\end{array}$ & 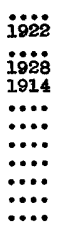 & $\begin{array}{r}1,145 \\
655 \\
400 \\
84 \\
300 \\
94 \\
98 \\
69 \\
78 \\
75 \\
57 \\
130\end{array}$ & $\begin{array}{l}8 \\
8 \\
8 \\
6 \\
4 \\
2 \\
2 \\
2 \\
2 \\
2 \\
2 \\
5\end{array}$ \\
\hline
\end{tabular}

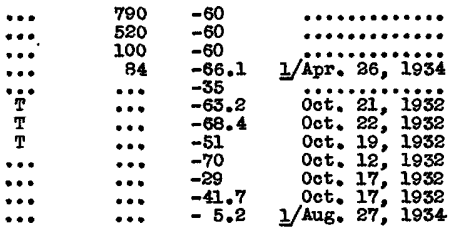

$\begin{array}{lll}106 & P & 78 \\ 106 & P & \because \cdots \\ 106 & P & \because \\ 104 & D r & \because 8 \\ 47 & P & 75 \\ 112.9 & \cdots & \because \\ 119 & \cdots & \because \\ 91.5 & \cdots & \because \\ 103.1 & \cdots & \because \\ 61.9 & \cdots & \because \cdots \\ 80.1 & \because \because 3 & \because \\ 104 & \text { Dr. } & \cdots\end{array}$

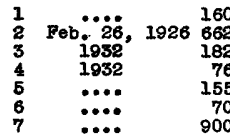

$\begin{array}{cc}12 & \mathrm{H} \\ 12 & 0 \\ 10 & \mathrm{H} \\ 6 & \cdots \\ 6 & 0 \\ 2.5 & \mathrm{H} \\ 6 & \cdots\end{array}$

Union County

1 Also measured on other dates; see table of well measurements.

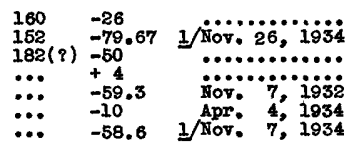

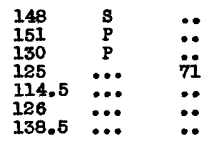

3. Also measured on other dates; see table 3 of Sarasots county report. 
Records of wells in the Florida peninsula - Continued

\begin{tabular}{|c|c|c|c|c|c|c|c|c|c|c|}
\hline \multirow{2}{*}{ No. } & \multirow{2}{*}{$\begin{array}{c}\text { Date } \\
\text { com- } \\
\text { pleted }\end{array}$} & \multirow{2}{*}{$\begin{array}{l}\text { Depth } \\
\text { (feet) }\end{array}$} & \multirow{2}{*}{$\begin{array}{l}\text { Diameter } \\
\text { (inches) }\end{array}$} & \multirow{2}{*}{ Source } & \multirow{2}{*}{$\begin{array}{l}\text { Depth of } \\
\text { casing } \\
\text { (feet) }\end{array}$} & \multicolumn{2}{|c|}{ Water level } & \multirow{2}{*}{$\begin{array}{l}\text { M. P. } \\
\text { (feet) }\end{array}$} & \multirow{2}{*}{ Use } & \multirow{2}{*}{$\begin{array}{l}\text { Temper- } \\
\text { ature } \\
\left(\mathrm{O}_{\mathrm{F}}\right)\end{array}$} \\
\hline & & & & & & Feet & Date & & & \\
\hline
\end{tabular}

Volusia County

\begin{tabular}{|c|c|c|c|c|c|c|c|c|c|c|}
\hline $\begin{array}{r}1 \\
2 \\
3 \\
4 \\
5 \\
6 \\
7 \\
8 \\
9 \\
10 \\
11 \\
12 \\
13\end{array}$ & $\begin{array}{c}\text { About } 1893 \\
1924 \\
1924 \\
\text { Dec. } 1932 \\
\text { May ïj32 } \\
1914 \\
1920 \\
1929 \\
1923 \\
1922 \\
1931\end{array}$ & $\begin{array}{l}160 \\
293 \\
480 \\
189 \\
125 \\
140 \\
160 \\
180 \\
135 \\
190 \\
180 \\
130 \\
141\end{array}$ & $\begin{array}{l}10 \\
24-12 \\
10 \\
10-8 \\
4 \\
2 \\
2 \\
4 \\
2 \\
6 \\
4 \\
4 \\
4\end{array}$ & $\begin{array}{l}0 \\
0 \\
0 \\
0 \\
0 \\
0 \\
0 \\
0 \\
0 \\
0 \\
0 \\
0 \\
0\end{array}$ & 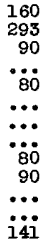 & $\begin{array}{l}-26 \\
-43 \\
-45 \\
-21.5 \\
-10 \\
+2 \\
+3 \\
+9.5 \\
+5.2 \\
+.1 \\
+4 \\
+1.2 \\
+1.2\end{array}$ & 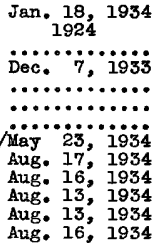 & $\begin{array}{r}38 \\
54 \\
56 \\
37 \\
25 \\
12 \\
18 \\
25 \\
6 \\
11 \\
12 \\
10 \\
14\end{array}$ & $\begin{array}{c}\mathrm{P} \\
\mathrm{P} \\
\mathrm{P} \\
\ddot{\mathrm{D}} \\
\mathrm{D} \\
\mathrm{D} \\
\ddot{\mathrm{F}} \\
\ddot{\cdots} \\
\ddot{\cdots} \\
\ddot{\cdots}\end{array}$ & $\begin{array}{l}\because \\
\because \\
\because \\
72 \\
73 \\
73 \\
76 \\
76 \\
73 \\
76 \\
76\end{array}$ \\
\hline
\end{tabular}

If Also measured on other dates; see table of well measurements.

Owners, location, and drillers of the wells, description of the measuring points, and remarks

(Abbreviations: D, driller; M. P., measiring point; A. C. L., Atlantic Coast Line Ratlroad; S. A. L., Seaboard Afr Line Railroad; J. S. F. D., United States Engineer Department; Surface, general surface of ground at well.)

\section{Alachua County}

1. A. C. I., High Springs. M. P., top of 8-inch casing, 25 feet below surface.

2. Town of High Springs, High Springs, D., R. J. Neikirk. M. P., surface.

2a. Town of High Springs, High Springs. D., E. A. Durst. M. P., top of 10-inch casing, 29 feet below surface.

3. Town of Alachua, Alachus, D., J. B. McCreary. M. P., top of concrete curb of pit, 1 foot above surface.

4. Well about $2.5 \mathrm{milles}$ southwest of Newberry, at old Neal phosphate mine, sec. 7, T. 10 S., R. 17 E. M. P., top of 12-inch casing, 35 feet below surface.

5. Town of Newberry, Newberry. D,, E. A. Durst. M. P., surface.

6. A. C. I., Newberry. M. P., top of 8-inch casing, $2 \dot{B}_{.6} 6$ feet below surface.

7. Maddox Foundry \& Machine Co., Archer. D., J. O. Edson. M. P., top of pump pit, 6 inches above surface.

8. B. C. Riley, well on State road 13 , about 1.5 miles north of Waldo, sec. 11, T. 8 S., R. 2l E.

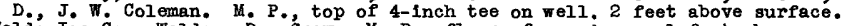

9. Waldo Ice Co., Waldo. D., Gray. M. P., floor of pump house, l foot above surface.

$9 a$. T. K. Godby, about $3 / 4$ mile south of Waldo. D., $T$. $K$, Godby. M, P., top of 3.5-inch casing, at surface. Seven flowing wells on property encountered limestone' at 25 feet.

10. A. C. I. creosoting plant, about 2 miles north of Gainesvilie, $D_{\bullet}, R_{*}$ M. Perry. M. P., floor of puinp house, 1 foot above surface.

11. Chemfcal Retort Co., about 2 miles north of Gainesville. D., Gray. M. P., pump base, 6 inches above surface.

12. Gainesville Ice Co., Gainesville. D., Gray. M. P., pump base, 2.5 feet above surface.

13. University of Florida, Gainesvilie. M. P., surface."

14. Weat Coast Ice Co., Gainesville. D., Gray \& Stevens, M. P., pump base, 1 foot above surface.

15. A. C. I., Rochelle. M. P., top of 6-inch casing, 6 inches above surface.

16. Florida Public Service Co., Hawthorn. M. P., top of 5-inch casing, 2.5 feet above surface.

17. J. R. Whiting, Micanopy. D., Barr \& Watkins. M. P., top of 6-inch casing, 1.5 feet above surface.

18. Power plant, Micanopy, M. P., top of 4-inch casing, 2 foet above surface.

19. I. Bell, about 0.8 mile northeast of Wade; U. S. E. D. I. M. P., surface.

20. O. C. Young, about $1.8 \mathrm{mlles}$ east of Alachua; U. S. E. D. 7. M." P., surface.

21. C. A. Priest, Arredondo; U. S. E. D. 58. M. P., surface.

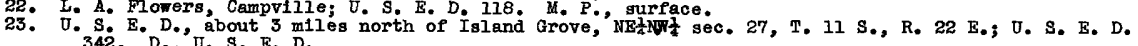

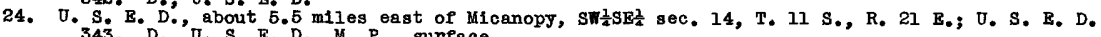
343. D., U. S. E. D. M. P., surface.

25. U. S. E. $\dot{D}_{*}$, about $i_{0} 3$ miles northwest of Micanopy, NW $\frac{1}{4} N E \frac{1}{4}$ sec. 27, T. 11 S., R. 20 E.; U. S. E. D. 344. D., U. S. E. D. M. P., surface.

Baker County

1. Olustee Experiment Forest Station, about 0.2 mile west of Olustee, sec. 2, T. 2 S., R. 22 E. D., Gray \& Stevens. M. P., pump base, 6 inches above surface.

2. U. S. E. D., about 5.5 miles northeast of kacclenny, sec. 2, T. 2 S., R. 22 E. D., O. S. B. D. H. P., surface.

3. School, Glen St. Mary. M. P., floor of pump house, same altitude as surface.

4. I. W. Dykes, Macclenny. $M . P .$, top of 2 -inch casing, same altitude as surface. 5. U. S. E. D. about 17 miles northeast of Lake City, iw $\frac{1}{4} N W \frac{1}{4}$ sec. 5, T. 2 S., R. 20 E.;

\section{Bradford County}

1. Town of Starke, Starke. M. P., bottom of 5-Inch flange on well, 3l feet above surface.

2. Town of Starke, Starke. D., Gray. M. P., 3.5 feet above gurface. Well drilled to depth of 300 feet in 1923; water level 20 feet below surface.

3. Town of Starke, Starke. M. P., surface.

\section{Brevard County}

1. Dixie Hotel, Tituspille. M. P., top of 3/4-inch pipe at pool 1 foot above surface. Water 1s very salty.

2. M. S. Whaley, Merritt Island, sec. 12, T. 22 S., R. 36 E. D., P. Harrod. M. P., top of casing at surface.

3. R. B. LaRoche, Courtenay. D., T. Sams. M. P., top of 3/4-1nch faucet about 150 feet south of weli, 1.5 feet above surface. 4. F. P. Porcher, about $\frac{1}{2}$ mile south of Courtenay. D., H. Bruntsch. M. P., top of 12-inch valve, 
Records of wells in the Florida peninsula - Contimued

Omers, location, and drillers of the wells, description of the messuring points, and remaris - Contimied

Brevard County - Continued

5. E. P. Porcher, Hall Hammoak, Merritt Island, D., Peck Harris, M. P., top of 2-inch valve 6 inches above 12 -inch casing, 2.5 feet above surface.

6. E. P. Porcher, Hall Hamock, Merritt Island, at Mrs. Wheeler's house. D., H. Bruntsch. I. P., top of 8-inch valve, 1 foot above surface.

7. U. S. Govermment, Canaveral I, Ight House. M. P., top of 1-inch valve, 10 feet north of $11 \mathrm{ght}-$ house and 1 foot above surface.

8. E. P. Porcher, Cocoa. D., H. Bruntsch. M. P., top of 10-inch casing, 4 feet above surface. C. A. Jones, Merritt Island, about $I$ mile north of Merritt, D., E. C. Smith. M. P., top of 3/4-inch faucet, at northeast corner of house, 1 foot above surface.

10. M. S. Whaley, about 1.5 mileg south of Rockledge. D., P. Harrod. M. P., top of 4-1nch valve, 4 feet above surface.

11. J. H. Pearson, about 1.5 mlles south of Bonaventure. M. P., top of 3/4-inch faucet on well, 1 foot above surface.

12. E. H. Schwartzberg, about 3 miles north of Eau Gallie. D., E. C. Smith. M, P., top of 3/4-inch pipe, 1 foot above surface.

13. Town of Eau Galife, Eau Gallie, D., E. C. Smith. M. P., top of 2-1nch plug in 6-inch tee, 4 feot above gurface.

14. Torn of Eau Gallie, Eau Galife, D., E. C. Sifth. M. P. pum base loot above surface.

14. Town of Eau Gallie, Eau Gallie. D, E. C. Smith. M. P. pump base, 1 foot above surface. above surface.

16. Mathers estate, south end of Merritt Island. M. P., top of 3/4-1nch faucet, 1 foot above

17. Mathergestate, at drambridge on south end of Merritt Island. D., E. C. Smith. M. P., top of 3/4-inch faucet, 13 feet above river level.

18. Mrs. W. B. Crouch, Palm Bay, M. P., top of 6 -inch valve at well, 4 feet above surface.

19. R. M. Wali, at St: Johns bridge 9 miles west of Melbourne. D., Hedges. M. P., top of 2-Inch well ter, I foot above surface.

20. Burkhard, about 9 miles west of Malabar, sec. 4, T. 29 S., R. 36 E. M. P., top of $3 / 4-1$. faucet at well, 1 foot above surface. 21. C. L. David son, about 4 miles west of Malabar, sec. 3, T. 28 S., R. 37 E. M. P., top of 1-1nch

22. Marshal Lumber Co., Malabar. D., E. C. Smith. M. P., top of 3/4-1nch faucet, 2 feet above surface.

23. Couch Mamufacturing Co., Grant. D., H. Bruntsch. M. P., pump base, at aurface.

24. Couch Manufacturing Co., Grant: D., H. Bruntgch. M. P., pump base, at surface.

24. Couch Manufacturing Co., Grant. D., H. Bruntsch. M. P., pump base, at surface.

26. S. W. Patcher, Micco. i. P., top of $3 / 4$-inch faucet, 2 feet below surface.

Broward County

1. Toun of Fort Lauderdale, Fort Lauderdale well 6. M. P., floor of pump house, 1.5 feet above surface. One of $\mathrm{six}$ shallow wells on golf course.

2. Town of Fort Lauderdale, Fort Lauderdale, at old plant. M. P., top of 10-inch casing, 6 inches above surface. Well reported to flow át times.

3. Port Evergiade 011 Co., Fort Lauderdale. D., Brom \& Posey. M. P., surface. Test well for oll.

Citrus county

1. Town of Crystal River, Crystal River. D., Gray. M. P., top of 10-1nch casing, same altitude as surface.

2. Ed Sayburn, Crystal RIver, D., R. I. Allen. M. P., top of 2t-1nch casing, at surface.

3. Ed Sayburn, Crystal River, $\mathrm{D}_{1}$ R. I. Allen, M, P., top of 2t-inch casing, at surface.

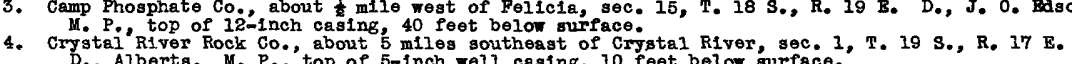

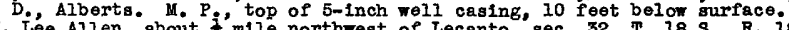

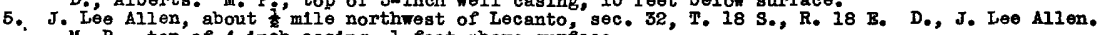
M. P., top of 4-1nch casing, I foot above surface.

6. H. Mayjárd, about 1 mlle northmest of Lecanto. D., J. Lee Allen. H. P., top of 4 -inch casing, 1 foot above surface.

7. Town of Inverness, Inverness. D., J. O. Bdson. M. P., surface.

8. J. 0. Edson, Floral City. D., J.'0. Edson. M. P., tóp of 2-1nch casing, 2 feet above surface.

9. J. Sint th, about 1.5 miles north of Floral C1ty; U.'S. E. D. 26. M. P., surface.

10. J. Roberts, about 0.8 mile north of Holder; U. S. E. D. 33. H, P.; top of casing, at surface.

11. H. A. Ross, Holder; U. S. B. D. 34. M. P. top of casing at suresce.

12. U. S. E. D. about 3 miles east of Holder; J. S. E. D. 32.9. D., U. S. E. D. Y. P., top of casing, at surface.

13. U. S. E.'D., about 2 miles south of Stokes Ferry, sEtket sec. 25, T. 17 S., R. 19 B. J. S. B. D.

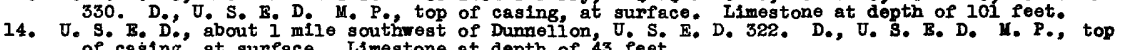
of casing, at surface. Limestone at depth of 43 feet.

15. U. S. E. D., about $1 \frac{1}{8}$ miles southwest of Dunnelion; U. S. E. D. 323. D., J. S. B. D.

16. M. $P_{.}$, top of casing, at surface. Limestone at depth of 54 feet. 16. U. S. E. D., about 2 miles southwest of Dumnelion, U. S. E. D. 324. D., U. S. B. D. M. P., Top

17. U. S. E. D.; about 3 miles west of Dunnellon, SElsw? sec., 5, T. 17 S., R. 18 B. U. S. B. D. 325. D., U. S."E. D. M. P. top of casing, at surface. No limestone penetrated.

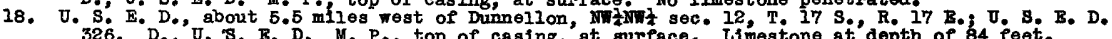

19. M. S. Greer, about 7 miles southwest of Dunneilon, sec. 15, T. 17 S., H. 17 B.; U. $\mathrm{B}$. B. D. 235.

20. A. D. Pilitems, Red Level, sec. 25, T. $178 .$, R. 16 E.; U. S. B. D. 239. H. P., top of casing, at surface.

\section{Clay County}

1. Yale Bxperiment Station, about 1 mile west of Orange Park, D., Dan woods. H, P., top of 6-inch p1pe, 6 inches above surface.

2. Mrs. H. Hall, Orange Park. D., H. Partridge, M. P., top of 3/4-1nch faucet, 2 feet above sur-

3. w. E. Parmenter, Orange Park, D., Allen. M. P., top of 3/4-inch faucet on well casing, 2 feet above surface.

4. R. Sasenett, Orange Park, D., I. T. Ivey. M. P., top of 3/4-inch faucet 20 feet southeast of weli, 2 fét above surface. 5. Jennings Artealan Farm Land Co,, about 7 miles northwest of Middleburg, sec. 17, T. 4 S.,
R. 24 E. D, Stafford. M. P., top of 3 -inch tee on weil, 2 feet above surface. 
Records of wells in the Fiorida peninsula - Contimued

Owners, location, and drillers of the wells, description of the measuring points, and remarks - Contimued

Clay County - Contimued

6. Columbus Brick \& Tile Co., Dixton, sec. 24, T. 4 6., R. 25 E. D., C. T. Ivey. M. P., top of tinch plug in 8-inch casing, 3 feet above surface.

7. Mrs. M. A. Chalker, Middleburg. D., Stafford. M. P., top of 3/4-inch faucet 4 feet south of well, 2 reet above surface.

8. F. Buddington, Middlebur.

D., Stafford. M. P., top of 3/4-inch faucet, 2 feet above surface. Leaky well.

9. Jennings Artesiap Farm Land Co., about 2 miles northeast of Mldaleburg, sec. 6, T. 5 S. R. 25 E. D., C. T. Ivey. K.'P., top of 3/4-inch pipe at 6-inch well tee, 2 feet above sur-

10. Orange Acreage, Russell. D., C. D. Ace. M. P., top of 3/4-inch faucet, 2 feet above surface.

11. L. H. McKee, Hibernia. D. $L$. T. Irey. $M . P$, top of 4-inch tee of weil, 2 feet above surface.

12. Girl Scout Camp, about 4 miles northwest of Green Cove Springs, T. 5 S., R. 26 E. D., L. Ivey. M. P., top of $6-1$ inch valve of well, 1.2 feet above surface.

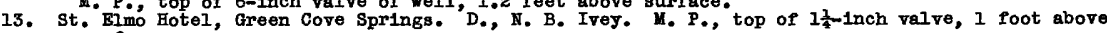
surface.

14. Town of Green Cove Springs, Green Cove Springs. D., L. Ivey, Y. P., top of 2-inch valve at wel1, 6 inches above surface.

15. Penney Grinn Farms, Nit $\frac{7}{4}$ sec. 17, T. 6 S., R. 24 E. D., Gray \& stevens. M. P., top of 6-inch casing, 1 foot above surface.

16. Penney Gínn Farms, Camphor Parm, sec. 16, T. $6 \mathrm{~S}$., R. 24 E. M. P., top of 5-inch casing, same altitude as surface.

17. Penney Ginn Farms, Black Creek well, sec. 13, T. 6 S., R. 24 E. M. P., top of 6-inch casing, at surface.

18. Penney Gulnn Farms, Horth Kentuciry Ave,, Penney Farms, sec, 8, T. 6 S., R. 25 E. D., Thompson. 14. P., top of 8-inch casing, 7 feet belor surface.

19. Penney Grinn Farms, c1ty well' 1, Penney Farms, sec. 16, T. 6 S., R. 25 E. D., Gray. M. P., pump base, 1.5 feet above surface. 20. Penney Gwinn Farms, Spring Bank Dairy, sec. 18, T. 6 S., R. 26 E. D., Gray. M. P., top of

21. Grant Van Sant, about 1 mile north of Valkill. M. P., top of 6-inch casing, $1 \frac{1}{k}$ feet above surface.

22. Green Cove Springs, Green Cove Springs afrport. M. P., center of 6-inch valve, 3 feet above surface.

23. Lou1s Ivey, about z mile northwest of West Tocol. D., Louis Irey. Y. P., top of 3/4-1nch plpe at 6 -inch valve, 6 inches above gurface.

24. J. 0 . Hobles, about fifle north of Fest Tocoi. D., J. Frazier. M. P., top of 3/4-inch faucet, 6 feet above surface.

Collier County

1. A. C. L., Imokalee. M. P., top of 6-1nch casing, 1.5 feet above surface.

2. Sam Thompson, Immokrlee. D', Sam Thompson. M. P., surface.

3. Hotel, Naples. M. P., top of $3 / 4$-1nch faucet, 1 foot above surface.

4. Deep Lake Co., Deep Lake, M. P., top of 3-1nch tee, 3 feet above surface.

5. Collier Corporation, well no. 1, Everglades. M. P., top of ell, 3 feet above surface.

Collier Corporation, power plant, well 3, Everglades, M. P., top of 3-inch valve, 2 feet above surface.

7. Collier Corporation, Bverglades, D., H. Raehn. M. P., top of 3-1nch tee, 3 feet above surface.

Columbia County

1. Tom of Lake City, about $3 / 4$ mile south of Lake City, sec. 5, T. 4 S., R. 17 F. D., Gray \& Stevens. M. P., top of 12-inch casing, 5 feet above surface.

2. Town of Lake City, Lake City. M. P., top of 6-inch el1, 4 feet above surface.

3. Bailey Bros., Blilaville. M. P., surface.

4. 0 . T. Harreil, about 16 miles south of Lake City on road 2, sec. 15, T. 6 S., R. 17 E. M. P., top of casing, 2 feet above surface.

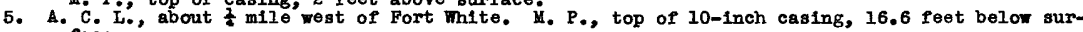
face.

6. R. F. Pearson, Fort Thite. M. P., top of pump, 2 feet above surface.

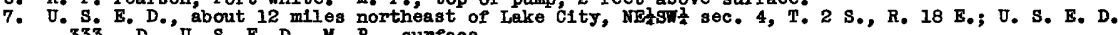

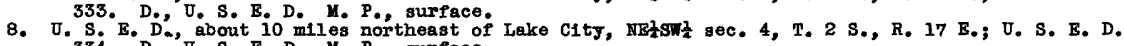
334. D., U. S. E. D. M. P., surface.

\section{Charlotte County}

1. Charlotte Harbor Hotel, Punta Gorda. D., R. A. Davla. M. P., top of 3/4-inch faucet, 1 foot above surface.

Dade county

1. J. Derring, 3250 Miaml Ave., Mlami. D., Kiser Drilling Co. M. P., surface.

2. Best Cosst' 011 \& Natural Gas Co., about' 2 miles osst of Kendali, sec. 12, T. 55 S., R, $40 \mathrm{~F}$, D., K1ser Drilling Co. M. P., top of 14-inch casing, at surface. Test well for" oil. No water reported below 1,800 feet. Head of 32 feet reported when drilled.

3. City of Kiami, 7 th St. And 57th Ave. ST., Miams. D., K1ser Drilling Co. M. P., top of 6-inch elbow at weil, 3 feet above surface.

4. Morlda, Royal Palm State Park. M. P., top of 2-inch tee, 6 inches above surface.

5. Town of Homestead, Homestead. D., K1 ser Drilling Co. M. P., surface.

6. Town of Homestead, Homestead, D.: K1ser Drilling Co. M. P.: surface.

Desoto County

1. 01d clty well of Arcadia, Arcadia. M. P., cap on well, same altitude as surface.

2. Town of Arcadia, Arcadia. D., R. J. Niekirk. M. P., top of $\frac{1}{4}$ - Inch pipe on prip, 1 foot below surface.

3. Carlatrom, about $8 \mathrm{miles}$ southwest of Arcadia. M. P., top of casing, 1 foot above ourface.

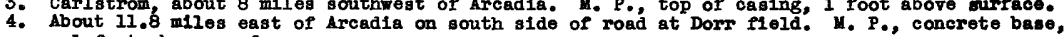
1 foot above surface.

Dural County

1. Town of Jacksonville Beach, Jacksonville Beach. M. P., top of 3/4-1nch pipe, 2 feet above surface.

2. Town of Jackeonville Beach, Jacksonville Beach, 2d St, between Rallroad and Pablo Aves.

H. P., top of $3 / 4-1$ nch pipe, 1 foot above surface. 
Records of wells in the Florida peninsula - Contimued

Owners, location, and drillers of the wells, description of the measuring polnts, and remarks - Continued

Dural County - Continued

3. Town of Neptune Beach, Florida Boulevard and F1rst St., Neptune Beach. D., Gray \& Stevens. M. P., top of -inch pipe in well casing, 1 foot above road surface.

Mrs. H. V. Sterens, at residence on north slde of road to Atlentic Beich, Nw $\frac{3}{4}$ sec. $24, T .2 \mathrm{~S} .$, R. 27 K. K. P., top of l-inch pipe, 3 feet above surface.

5. Jacksonvilie Gas Ćo., Acorm and Church Sts., Jacksonville. K. P., top of 3/8-1nch pipe above top

6. City of Jacksonvilie, Huron and Enterprise Sts., woodstock Park, Jacksonville. M. P., top of tinch pipe, 2 feet above concrete floor of pump house.

7. P. Relsz, at Relsz Dairy, on north side of highway to Baldwin 0.6 mile west of Jacksonville city Iimits. D., Wiggins. M. P., top of 3/4-1nch plpe, 2 feet above concrete floor of dairy barn.

8. City of Jacksonvilie, Pangma Park, 63d St. west of Buffalo St., Jacksonville. D., E. A. Durst. H. P., top of $\frac{1}{4}$-inch outlet, 2 feet above surface of pump-house floor.

8. Hunicipal Golf links, Wunlclpal Golf Links, Golfalr Boulevard and Moncrief Road, Jacksonvilie. D., E. A. Durst. M. P., top of plpe on pump, 2 feet above surface.

10. Mexican oli Corporation, Talleyrand Ave., Jacksonville. D., Wiggins, M. P., top of plpe, 4 feet above surface.

11. Ribault Club, Ribault Club, Fort George Island. D., I. A. Durgt. M. P., top of 3/4-1nch p1pe, 1.5 feet above surface.

12. City of Jacksonvilie, south of post office in Ortega. D., Hugh Partridge. M. P., top of 3/4inch pipe, 6 inches above surface.

13. Venetian Yacht Club, south of Ortegi, on St. Johns R1ver. D., Hugh Partr1dge. M. P., top of 3/4-inch plpe, I foot above surface.

14. U. S. RIfle Range, near Yukon U. S. Rifle Range. M. P., top of $\frac{1}{4}-1$ inch plpe, 4 feet above sur-

15. W. S. Stover, Dinsmore, D., J. W. Sheffield. M. P., top of 3/4-1nch plpe, 1 foot above sur-

16. B. H. Carlton, southwest of Dinsmore near Spalding. M. P., top of 3/4-inch pipe, 1 foot above surface.

17. Bayshore Co., west of Fort George, on east side of sister Creek and north side of St. Johns River. D.; E. A. Durst. M. P.; top of 3/4-1nch pipe, 2.5 feet above aurface.

18. Waterworks Párk, Jacksonville. Ḿ. P., surface.

18. G. C. Cole, sec. 10, T. I S., R. 26 E., about 1 mile north of Trout Creek on Lem Turner Roed. D., Gray \& Stevens. M. P., top of 4-Inch tee on well, same altitude as aurface. Pressure head of water in Hawthorn formation is 2.5 feet above surface.

20. J. Beard, Baldwin. M. P., top of 2-1nch casing, 5 feet above surface.

21. Fred Lucas, Haxvilie. D.; Fred Iucas. M. P., top of casing, 2 feet above surface.

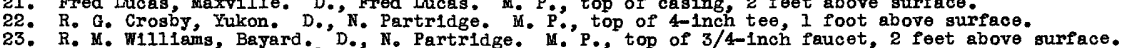

24. Joe Quattlebaum, about ${ }^{2}$ mile north of Marietta. "D., Hooten \& Lewis, M. P., top of 6-1nch valve, 3 ebaum, about $\frac{1}{8}$ mile

25. L. W. Bowman, sec. ?, T. $3 \mathrm{~S}_{.}, \mathrm{R}_{.} 26 \mathrm{E}$., on old Orange Park Road, Jacksonville. M. P., top of 6-inch plpe, 1.5 feet above surface.

\section{Flagler County}

1. Mellon \& Hilliard, Sumer Haven. D., G. Brunner. M. P., top of 3/4-Inch faucet, 2 feet above surface.

2. John Bartrees, Summer Haven. D., H. Walker. M. P., top of 3/4-inch faucet, 1 foot above surface.

3. Washington Place, about 6 miles south of Summer Haven, on east side of highway. D., H. Walker.

4. Johnson Farms, sec. 4, T. 11 S., R. 31 E., Johnson Farns. D., Allen \& Merserve. M. P., top of 3/4-inch' faucet, 2.5 feet above surface.

5. George Brunner, aboat 2.5 miles north of Flagler Beach. D., Brown. M. P., top of 4-1nch tee, 2 feet above surface.

6. G. M. Moody, at canal about 1 mile west of Flagler Beach. D., George Brunner. M. P., top of 2-1nch pipe, 1.5 feet above gurface.

7. R. W. Cody, sec. 30, T. 13 S., R. 30 E., near Haw Creek. D., R. Melton. M. P., top of 4-inch

8. J. Dahlquist, sec. 30, T. 13 S., R. 30 E. D., N. J. White. M. P., top of 4-inch casing, at surface.

9. N. E. Roberts, sec. 30, T. 13 S., R. 30 E. D., N. J. White. M. P., surface. 10. John Campbell, Sheil Bluff, sec.'33, T. II S., R. 28 E. M. P., top of 2-Inch pipe, 53 feet

11. E. F. Warner, St. Johns Park. M. P., top of 1 3/4-1noh pipe, 1 foot above surface.

12. Lambert \& Moody, Bunnell. D., N. H." Monck, i. P., surface.

13. Town of Bunnell, Bunnell. M. P., surface.

\section{Gilchrist county}

1. V. W. Mimus, Trenton. D., Minns \& Hodge. M. P., top of 5-1nch casing, 19 feet below surface. 2. Coca Cola Bottling Co., Trenton. M. P., top of casing 0.3 foot above surface.

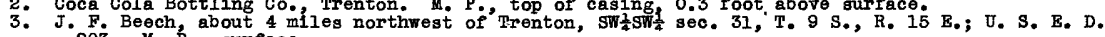
203. M. P., surface.

4. J. H. MoDade, 'Lottlevilie, sec. 15, T. 10 S., R. 14 E.; U. S. E. D. 204. M. P., gurface.

5. Barron, Bell; U. S. E. D. 4. H. P., surface.

6. C. Langford, about 5 miles west of Newberry; U. S. E. D, 207. M. P., surface.

7. A. C. I., Wilcox Junction. M. P., top of 8-inch casing, 5 feet above surface.

Glades County

1. R. J. Brewton, Pajmdale, M. P., top of 4-inch p1pe, 3 feet above surface.

2. Town of Moore Haven, Moore Haven.

\section{Hamflton County}

1. Town of Jennings, Jennings. D., W. R. McGrew, M. P., top of 6-1nch casing, 6 inches below surface.

2. Town of Jasper, Jasper. D., Gray \& Stevens, M. P., pump-house base, 2 feet above surface.

3. Town of Jasper, Jasper. M.'P., pump-house base, I foot above surface.

4. Town of thite Springs, White Springs. D., Maine Fngineering Co. M. P., top of 3/4-1nch plug in ell on 10-1nch pipe, 1 foot below surface. 
Records of wells in the florida peningule - Continued

Owners, location, and drillers of the wells, description of the measuring points, and remerks - Continued

Hardee County

1. Florida Public Service Co., Bowling Green. M. P., top of 6-inch casing, 6 inches above surface.

2. Judge fiarrison, about 2 miles southeast of Zolfa Springs. M. P., top of 6-inch pipe, 2 feet above surface.

3. Tom of Wauchula, Wauchula. D., E. A, Durgt. M. P., surface.

Hendry County

1. Collier Corporation, about 3 mileg west of La Belle, sec. I, T. 43 S., R. 28 E. M. P., top

2. Bverett Hotel, La Beile. D., Kellog. M. P., top of 3/4-1nch faucet, 6 feet above surface.

Rer'nando County

I. William Panell, Stafford, sec. 29, T. 21 S., R. 19 E. M. P., top of 8-Inch ceging, 2 feet liliam Panell, stafford, gec. 29, T. 21 S., R. 19 E., wegt of leveo. M. P., top of 8-1nch casing, 1 foot below surface.

3. J. S. Agricultural Experiment Station, about 5 mileg north of Brookgville. M. P., pump bese, at surface.

4. Quinn Snow, ebout $6.5 \mathrm{mlleg}$ north of Brookgville, sec. 30, T. 21 S., R. 20 E. M. P., top of 18-inch caging, 1 foot above surface.

5. Mrs. C. M. Baxley, about 2 mileg west of Igtachatta. M. P., pump bage, 1 foot above surface.

6. L. S. MeKnight, Istachatta. M. P., gurface.

6a. Town of Istachatta, Istachatta; U. S. E. D. 28, M. P., gurface.

7. Henry Goethe, Bayport. D., Goodspeed. M. P., top of pitcher pump, 5 feet above surface,

8. Wright Rock P1t, about 4 miles west of Brooksilile, gec. 24, T. 22 S., R. 18 E. M. P., top of 5 -inch caging, 1 foot above gurface.

9. Town of Brookgville, Brookgville; city well 2. D, J. Hilliard. M. P., top of 18-1nch casing, 6 inches below surface.

10. Town of Brookgville, Brooksville; well 1. M. P., surface.

11. Cam Rock Co., about 7 mileg northeast of Brooksilile, gec. 8, T. 22 S., R. 20 E. D., J. 0.

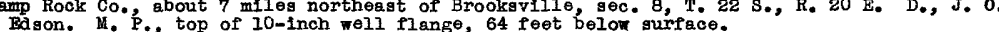

12. Camp Rock Co., gbout $7 \mathrm{mlles}$ northergt of Brookgvilie, gec. 8, T. 22 S., R. 20 E. D., J. 0. Edson. M. P., top of 10-1nch well flange, 64 feet below surface.

13. Larry McKeown, Crocm. M, P., pump base, 2 feet above surface. 14. J. Butgenback, about 2 miles gouthwegt of Croom at phosphate mine. D., J. Edson. M. P., gux-
face.

15. Misg M. Cotton, Redell. M. P., top of caging, 6 feet below surface.

16. Garden Groves, Inc., about 6 ifles south of Brooksville, sec. 17, T. 23 S., R. 19 E. D., J. Hilliard. H. P., gurface.

17. A. C. L., Crocm; U. S. E. D. 154. M. P., gurface.

\section{Highlands County}

1. Brighton Valley Hotel, Brighton, about 17 mileg west of 0keechobee. M. P., top of 3/4-inch faucet, 4 feet above surface.

2. Town of Sebring, Sebring. M. P., top of caging, 4 feet above surface.

4. John A. Roebling, about $10 \mathrm{mlleg}$ south of Lake Placid, sec. 7, T. 38 S., R. 30 E. D., Layne Southeastern Co. M. P., surface.

\section{H111sborough County}

1. Pinellas Water Co., southwest of Cosme, east of road near aerating plant, NWWWW sec. 34,

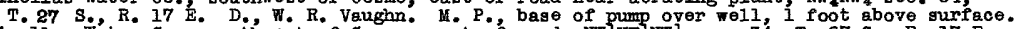

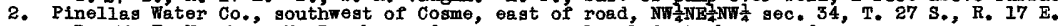
D., W. R. Vaughn. M. P., bage of pump over well, 1 foot above surface.

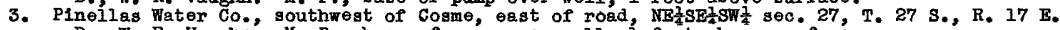
D., W. R. Vaughn. M. P., base of pump over well, 1 foot above gurface.

4. Pineilis. Water Co., gouthwest of Cosme, north gide of road, SE NW $\frac{1}{4} S W \frac{1}{4} \mathrm{gec} .27, \mathrm{~T} .27 \mathrm{~S} .$, R. 17 E. D., W. 'R. Vaughn. M. P., bage of pump over weil, 1 foot above gurface.

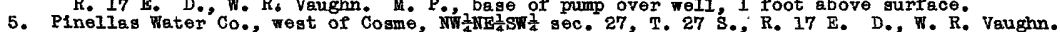
M. P., base of , west of Cosme, NW

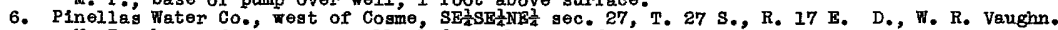
M. P., base of pump over well, i foot above surface.

7. Pinellas Water Co., west of Gunn Highway, SW

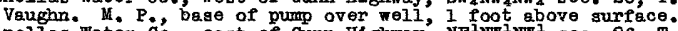

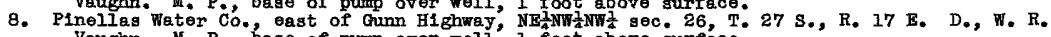
Vaughn. M. P., base of pump over veli; 1 foot above surface.

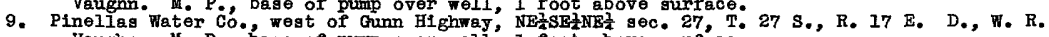
Vaughn. M. P., bage of pump over well, 1 foot above surféce.

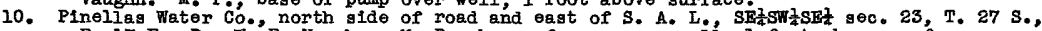
R. 17 E. D., W. R. Vaughn. M. P., bage of pump over weli, 1 foot above gurface.

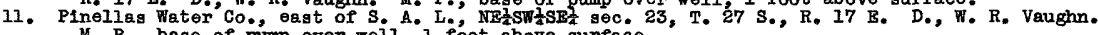
M. P., base of pump over well, 1 foot above surface.

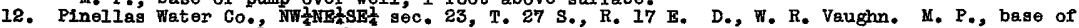
pump over well, i foot sbove surfece.

13. Pinellas Water Co., sec. 21, T. 27 S., R. 18 E. D., W. R. Vaughn, M. P., bage of pump over well, about 0.5 foot above top of wéli caging and' 1 foot obove surfec:

14. Florida Public Service Co. Sun City, at power plant on west gide of rosd. D., D. W. Dansby. M. P., top of 2.5 -inch pipe, game altitude as surface of road.

15. About $\dot{2}$ mileg north of railroed station at Rugkin, west of road, in field near farmhouge.

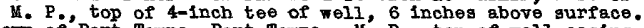

16. Town of Port Tampa, Port Tampa. $M$. P., top of well casing, same altitude a surface.

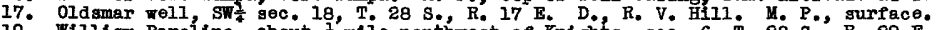

19. Willism Parolina, about timile northwest of Knights, gec. 6, T. 28 S., R. 22 E. D., W1111am

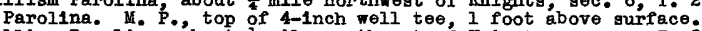

20. William Parolina, ibout $\frac{1}{4}$ mile northrest of Knlghts, gec. 6, T. 28 S., R. 22 E. D., William Parolina. M. P., top of 4-inch well tee, 2 feet below surface.

21. P. H. Varnes, about $\frac{1}{4}$ mile south of Seffner, sec. 11, T. 29 S., R. 20 E. D., WIlliam Powell.

22. L. S. ḾcIntosh, about 1.5 miles west of Dover, sec. 6, T. 29 S., R. 21 E. M. P., top of 4-inch

23. Town of Plant City, Plant City; well 1. D., Lajne Bowler. M. P., pump base, at surface. 
Records of wells in the Florida peninsula - Dontinued

Owners, location, and drillers of the wells, description of the measuring points, and remarks - Continued

Hillsborough County - Continued

24. Town of Plant City, Plant City; well 2. M. P., top of concrete plt cover, 4 feet above surface.

25. Tow of Plant Gity, Plant Gity, well 3. D., R. Neikirk, M. P., top of pump base, 6 inches above surface.

26. American Agricuiturel Chemlesl Co., Carmicheel well 9, sec, 6, T. 30 S., R. 22 E. D., Layne

27. American Agricultural Chemical Co. Carmicheol weil 1 , sec. 18, T. 30 s., R. 22 E. D., V1rginia Machinery \& Fell Drliling co. M. P., top of it-inch horizontal coupling, I f feet above surface.

\section{Indian R1ver Oounty}

1. E. H. Every, about 1 mile northeast of Fellomere, sec. 14, T. 31 S., R. 37 E. D., C. V. Man-

ning. M. P., top of 4-inch valve on well, 1.5 feet above surface.

2. A. W. Crandali; about 1 mile southwest of Fellsmere, sec. 22, T. 31 S., R. 37 B. M. P., top of $3 / 4$-inch faucet, 1.5 feet above aurface.

3. L. G. Hardee, Sebastian. D., Frank Young. M. P., top of 2-1nch valve, 2 feet above surface.

4. L. G. Hardee, Sebastian. D., John Yorgeson. M. P., top of 5-1nch valve, 1 foot above aurface.

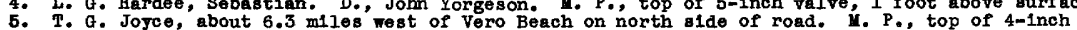

T. G. Joyce, about 6.3 miles

6. F. F. Cobb, Intergection of road 30 and 37 th st., Vero Beach. M. P., top of 4-1nch p1pe, 2 feet above surface.

7. Tom of Vero Beach, Vero Beach, 2lst st. and 14th Aye. Y. P., top of 3/4-inch pipe, same altitude as surface of road and sidewalk.

8. T. J. Anderson, Fellsmere. D., C. W. Wanning. M. P., top of $3 / 4-1$ nch pipe, 3 feot above surface.

9. Fellsmere Fater Co., Fellsmere. M. P., surface.

10. Town of Vero Beach, Vero Beach. M. P. surface.

11. Mrs. Isaac M. Felis, about mile southeast of Vero Beach. D., W. Duncan. M. P., top of 4-inch tee, 3 feet above surface.

\section{Lake County}

1. 0. K. 1ce plant, clermont. M. P., top of concrete well pit, at surface, Il feet above top of weil casing.

2. Town of Clermont, south edge of Sunny S1de Lake, Clermont. D., C. B. Hall. M. P., top of casing, same altitude as surface.

3. Town of Clermont, Clermont. D., Gray \& Stevens. M. P., top of well casing, same altitude as surface.

4. Town of Ciermont, Clermont. D., Gray \& Stevens. M. P., top of well casing, same altitude as surface.

5. Tom of Groveland, Groveland. D., McCloud \& Conant. M. P., top of concrete rim of pump pit, same altitude as surface and 12 feet above top of well casing.

6. About 1.4 mlles east of Groveland and north of road and raflroad. M. P., top of 4-1nch casing, 6 inches above surface.

7. Tom of Montverde, about 200 yards north of rallroad station at Montrerde. D., John R. Matthews. M. P., top of casing, at surface.

8. Florlda Public Service Co., 5th Ave. and East Broad St., Tavares. M. P., top of casing, 2 feet above aurface.

9. Florlda Public Service Co,, 5th Ave. and East Broad St., Tavares. M. P., top of casing, 2 feet above surface.

10. Florida Public Service Co., Eustis. M. P., aurface.

11. Florida Public Service Co., Eustis. M. P., gurface.

11. J. Philip Doss, Jr., Astor. M. P., top of conerete rim at well, 10 inches above surface.

12. Astor School, achoolhouse, Astor. Y. P., top of 2-inch tee on well, 15 inches

13a. Tom of Leesburg, Leesburg; U. S. B. D. 143. H. P., surface.

14. Lake County Clay Co., about 4 miles east of Okammpica. Y. P., top of 6-1nch casing, 6.5 feet below surface.

15. Tow of Umatilla, Umatilla; U. S. E. D. 163, M, P., surface.

16. C. W. Bayless, Grand Island; U. S. E. D. 160. M. P., surface.

\section{Lee county}

1. Western Union Telegraph Co., Punta Rasa. D., Dukes, M. P., top of 3/4-inch valve, 3 feet above surface.

2. E. E. Goodno, about $t$ mile northeast of Punta Rasa. M. P., top of 3/4-inch pipe, 3 feet above surface.

3. E. E. Goodno, about mile northeast of Punta Rasa. M. P., top of 3/4-inch pipo, 3.5 feet above aurface.

4. Joe Maharry, sec. 21, T. 45 S., R. 24 B. Do, Joe laharry, Y, P., top of 6-1nch tee, 1 foot above surface.

5. John Deen, sec. 21, T. 45 S., R. 24 E. D., Joe laharry. M. P., top of 2-inch valve, 1 foot above surface.

6. E. Roundtree, sec. 2, T. 45 S., R. 24 E. M. P., top of 3-inch elbow, 6.5 feet above surface.

7. Town of Fort Myers, Fort Hyers, at swiming pooí. D., Joe Maharry. M. P., top of $3 / 4-1$ inch plug, 2 feot above surface.

8. Dowling \& Cemp, Slater, sec. 18, T. 43 S., R. 25 E. M. P., top of 1-1nch plpe, 17 feet above surface.

9. 0lge School, 01ge, sec. 27, T. 43 S., R. 25 E. D., Darlason. M. P., top of 3/4-1nch pipe 200 feet north of well, 2 foet above surface.

9a. Olga Garage, Olga. M. P., surface.

10. F. H. Alexander, about $S$ mlles south of Fort Kyers, sec. 35, T. 45 S., R. 24 B. D., Alderaan. 1. P., top of 4-inch too, 1 foot above surface.

11. F. H. Alexander, about 8 miles south of Fort Yyers, sec. 35, T. 45 S., R. 24 B. D., 0. C.

11. Prowbridge. M. P., top of $3 / 4-1$ nch fauoet at weil, 1 foot above aurface.

12. Flowere Qrove, Inc., about $3 / 4$ mile northeast of Batero, sec. 27, T. 46 S., R. 25 .

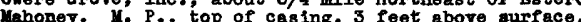

13. Will Gibson, on Cocoanut road, sec. 8, T. 47 S., R. 25 R. D., Joe Mahoney. M. P., top of 6-1nch p1pe, 2 feet above aurface.

14. W. B. Baker, about 1 mile west of Bonita springs. M. P., top of 3/4-inch pipe, 2.5 feot above surface.

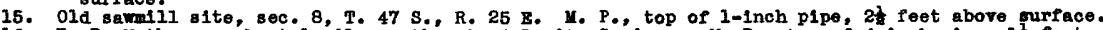

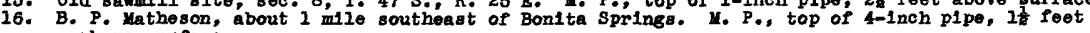
above surface.

17. H. Y. Thome, about 1.5 miles southosst of Bonita springs. D., Barnes. M. P., top of 3-inch pipe, 2 feet above surface. 
Records of wolls in the Flcrida peninsula - Continued

0mers, location, and drillers of the wells, description cf the measuring points, and remarks - Oontinued

Lee County - Continued

18. B. P. Matheson, about 1.7 miles southeast ce Bonita Springs. D., J. Maharry. M. P., top of 4-inch plpe, 2 feet above surface.

Lery County

1. Bronson Manufacturing Co., about $\frac{1}{2}$ mile west of Bronson. H. P., top of 8-inch casing, 1 foot above surface.

2. Town of Filliston, Filliston. D., Rhoades, Y. P., pump base, at surface.

3. State Road Department, about t mile west of wililition. M. P., top of 3-inch casing, 1 foot above surface.

4. Tow of Codar Keys, Cedar Keys. D., Dunlap, M. P., top of 4-1nch plug, 1 foot below surface. Water would rise 6 feot above surface in 1928.

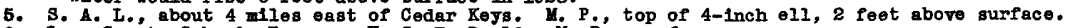

6. Lery County School, Bronson; U. S. E. D. 16. H. P'., surface.

7. Lery Coninty School, Bronson; U. S. E. D. 16. K. P., sur

7. W. S. Wood, Chlefland; J. S. E. D. 132. M. P., aurface.

8. T. S. Yearty, Otter Creek; J. S. E. D. 134. M. P., surface., J. S. E. D. 135. M. P., surface.

9. D. P. Albritton, Lebanon Station, sec. 24, T. 15 B., R. 16 g. I J. S. E. D. 135. M. P. surface.

11. J. T. Flówers, about 0.5 mile east of Kontbrook; U. S. B. D. I1. M. P., top of casing, at surface.

12. Wiliston Crate Go., about 1 mile east of Vil11ston; J. S. E. D. 12. M. P., top of casing, at

13. J. S. E. D., about 2 miles north of Williston; J. S. E. D. 219. D., J. S. B. D. M. P., surface.

14. Cooper Turpentine Co., Sumer, sec. 36, T. 14 S., R. 13 E.; U. S. B. D. 209. M. P., surface.

15. G. C. Perdue, Wylly, sec. 22, T. 14 S., R. 14 E.; U. S. E. D. 210. M. P., surface.

16. U. S. E. D., about 7 miles southwest of Nilliaton; D. S. B. D. 346. D., U. S. E. D. M. P., surface

17. U. S. F. D., about 7 miles southeast of otter Creek; D. S. B. D. 347. D., D. S. E. D. M. P., surface.

18. U. S. E. D., Gulf Ramond; J. S. B. D. 348, D., J. S. B. D. M, P., surface.

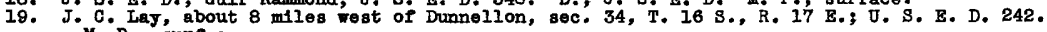
M. P., surface.

20. J. S. E. D., near Yankeetom, sec. 5, T. 17 S., R. 16 E.; J. S. E. D. 353. D., U. S. E. D.

21. J. S. B. D., sec. 5, T. 17 S., R. 17 E.; J. S. E. D. 390. D., U. S. E. D. M. P., top of casing, at surface.

22. R. Hodges, Cedar Keys; J. S. E. D. 20s. M. P., surface.

Wanatee County

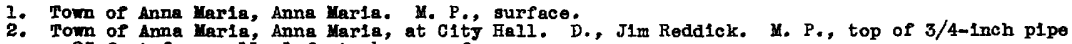
25 feet from well, I foot above surface.

3. Town of Anna Marla, Anna Maria, near City Hall. D., Danfelson. M. P., surface.

4. Town of Anna Harla, Anna Maria, at post office. D., Danfelson. M. P., surface.

5. Anng

6. H. C. Dltmas, about 2 mile sovtheast of Anna Maria. D., T. W. Johnson. M. P., aurface.

6. H. C. Ditmas, about ? mile sovtheast of Anna Maria. D., T. W. Johnson.

8. Bradention Beach bath house, Eredenton Beach. D., R. I. Nixon. M. P., top of 3/4-inch pipe, 1.5 feet above surface.

9. Anne Maria Key, south of Anna Maria. M. P., surface.

10. G. M. Stafford, Bradenton Beach, south of Cortez road. D., T. W. Johnson. M. P., aurface.

11. Town of Anna Maria, at south sido of Anna Maria. M. P., surface.

12. Bradenton Beach, on east side of read south of bath house. M. P., surface.

13. Pat Green, Cortez, at old club house. M. P., surface. 14. D. S. Fulferd, Cortez, on road near Sarasota' Pass, south side of road at residence. M. P., top

15. Joe Gutherie, Cortez, at Albion Inn Hotel. M. P., top of 3/4-1nch pipe near well, same eltitude as surface.

16. Cortez Public School, Cortez, at school house. M. P., top of 3/4-1nch pipe near well, 1.5 feet above surface.

17. 0. B. Plaisted, northeast of Cortez, near Palma Sola Bay. M. P., gurface.

1S. Southeast of Corter, near Sarasota Bay. M. P., surface.

19. J. A. Frohock, Inspiration ranch, east of Cortez, M. P., surface.

20. M. Levine, esst of Cortez, sec. 8, T. $35 \mathrm{~S} ., \mathrm{R}$. it $\mathrm{g}$.

21. M. Levine, east of Cortez, sec. 8, T. $35 \mathrm{~S}$, , R. $17 \mathrm{~g}$.

22. J. Levine, east of Corter, aec. 8, T. $35 \mathrm{~S}$, R. $17 \mathrm{~g}$. P. surface.

23. J. T. Fleming, Fleming farm, south of east-west road, ti mile west of Palma Sola Loop. D., J. T. Fleming, Fleming farm, south of east-west road, t mlle west of Palma Sola Loop. D., W.

24. J. T. Floming, Fleming farm, south of east-west road, te mile west of Palma Bola Loop. D., T. Redalok. M. P., surface.

25. J. T. Fleming, Flemíng Parm, south of east-west road, th mlle west of Palma Sola Loop. D., 1 . T. Reddick. M. P., surface.

26. J. T. Floming, Fleming Farm, sonth of east-west road, th mile west of Palme Sola toop. D., W. T. Reddick. Y. P., surface.

27. J. T. Fleming, Fleming Parm, south of east-rest road, to mile west of Palma Sola Ioop. D., w. T. Reddick. M. P., surfaco.

28. R. O. Duffie, south side cf Palma Sola Loop. M. P., surface.

29. R. O. Duffie, south side of Palma Sola Loop. D., T. T. Johnson.

30. F. R. Smith, south alde of Palma sola Loop. D., E. J. Pettigreir. M. P., aurface.

31. B. H. Van ICtwick, west end of Pajma Sola Loop. M. P., surface.

32. F. Z. Smith, Palma Sola Loop, Ione Palm Preserving Co. M. P., surface.

33. F. B. S. HeDoneld, 4th Ave. and 75th St. Bradenton. M. P., surface.

33. B. S. lloboneld, 4th Ave, and 75th St. Bradenton. M. P., gurface.

34. Regsoner Brcs. ncrthwest corner of Palma Sola Loop. D., E. J. Pettigrew. M. P., surface.

35. Olty of Bradenton, clty water plart, Bradenton. D., Virginia Hachinery \& Veli Driling Co.

1ty of Bradenton, elty water plar.t, Bradenton. Di, Virgin
M. P., top of t-inch pipe on purp, 2 feet above surface.

36. Olty of Bradenton, eity water plant, Bradenton. D., Virginia Wachinery \& Well Drilling Co.

37. Bxcelsior Ico CC.: Bradenton.

38. Brcels1or Ice Cc., Bradenton. D., D. W. Dansby.

39. Citj of Bradenton, nerth side of Central Ave. at east end of Ware Bridge, Bradenton. 1. P., plpe on well, 2 foet above surface.

40. R. O. Póelman, Tamiani Trail, 4 nillos south of Bradenton. D., R. C. Pomelman. M. P., top cr 3/4-inch pipe at vell, 2 foot abovo surface. 
Records of wells in the Floride peninsula - Continued

Owmers, location, and drillers of the wells, description of the measuring points, and remarks - Continued

Manatee County - Continued

41. George Parker, Cortez road and Tamiam1 Tra1l. M. P., surface.

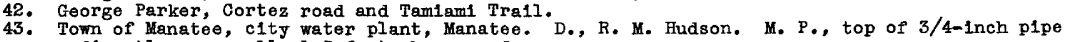
directly over well, 1.5 feet above surfece.

44. S. Frank Perkins, 7th St. and Manatee Ave., Manatee. M. P., top of $3 / 4-i n c h$ plpe on well, 4 feet above surface.

45. J. S. Yates, about 1 mile south of Manatee, Swi sec. 31, T. 34 S., R. 18 E. M. P., surface.

46. Florida Travertine Corporation, southeast of Manatee, at travertine quarry, sec. 5 , T. $36 \mathrm{~S}$., lorida Travertine Corporation, southeast of Ma

47. E. I. Ayres, southeast of kanatee, southesst corner sec. $32, T, 34$ S., R. 18. E. M. P., surE. Lace. Ayse.

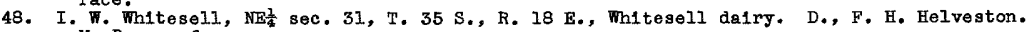
M. P., surface.

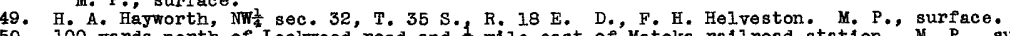

50. 100 yards north of Lockwood road and $\frac{1}{2}$ mile east of Matoke rallroad station.' M. P., surface.

51. Elmo Saunders, Range Line road and Saunders slding, south of Manatee. $\mathbb{K}$. P., top of $3 / 4-1$ inch pipe, 2 feet above surface.

52. H. R. Hunt, Range Llne road and Saunders siding, south of Manatee. D., Powell. M. P., surface.

53. H. K. Jaimson, Range Line rosd and Saunders siding, south of Manatee. D., Reddick. M. P.,. surface.

54. Brown estate, Brown place, near Rye. M. P., surface.

55. J. E. McCloud, Myakra C1ty. M. P., surface.

56. E. E. Edge, Myakka C1ty.

57. J. E. Jones, Terra Cela Island. M. P., surface.

58. Pillsbury estate, Snead Island, Pllisbury farm. M. P., top of 3/4-1nch pipe at well, 2 feet above surface.

Pillsbury estate, Snead Island. M. P., surface.

60. Pillsbury estate, Snead Island. M. P., surface.

61. Pillsbury estate, Snead Island. M. P., surface.

63. Dutton \& Singletary, Snead Island. M. P., surface.

64. A. M. Vassel, near city IImlt of Palmettó, on south side of boulevard to snead Island. M. P., top of $3 / 4-1$ nch pipe on well, 5 feet above surface.

D. F. Richards, west of Palmetto. M. P., surface.

66. M. E. Robinson, northwest part of Palmetto. M. P., surface.

67. W. E. Robinson, northwest part of Palmetto. M. P., surface.

68. W. E. Robinson, about 50 feet north of weli 67. M. P., surface.

69. W. E. Robinson, southeast of wel1 67. M. P., surface.

70. E. H. Morse and C. J. Heasler, northwest part of Palmetto, east of wells 66 and 67 . D., C. Heasler. M. P. top of 4-1nch pipe on well, 5 feet above surface.

T. E. Robinson, SE $\frac{1}{4}$ sec. 10 , T. 34 S., R. 17 E.

Gity of Palmetto, Palmetto, at water plant. M. P., top of 3/4-1nch p1pe, 1 foot above surface. city of Palmetto, Palmetto, at water plant.

73. City of Palmetto, Palmetto, at water plant.

75. Town of Ellenton, Elienton. D. Styles. J. F. Mixon, east side of rosd at Mixon residence, north of Rubonia, sec. 18, T. 33 S., R. $18 \mathrm{E}$ Harold Hahn, east side of road at Hahn residence, north of Rubonia, sec. 18, T. $33 \mathrm{~S} ., \mathrm{K} .18 \mathrm{E}$.

77. G. W. Barmes, sec. 7, T. 33 S., R. 1.8 E. D., Cannon. M. P., top of 3/4-1nch pipe over well, 4 feet above surface.

78. J. C. Miley, sec. 29, T. 33 S., R. $18 \mathrm{E}$. M. P., surface.

79. T. E. Purdon, sec. 7, T. 33 S., R. 18 E. M. P.', surface.

80. J. P. Harliee, sec. 31, T. 33 S., R. 18 E. D., E. J. Pettigrew. M. P., surface.

81. Webster \& Halsey, Piney Point. D., John Anderson. M. P., top of $2-1$ inch pipe on well, same altitude as crown of road.

82. Piney Point Land Co, Piney Point. D., I. I. Safford.

83. J. P. Harllee, sec. 18, T. 34 S., R. 18 E. D., E. J. Pettigrew. M. P., surface.

84. H. W. Harrison, sec. 3, T. 34 S., R. 17 E. D., John Mitchell. M. P., surface.

85. J. P. Harllee, sec. 30, T. 34 S., R. 18 E. D., E. J. Pettigrew. M. P., surface.

W. P. Frler, Parrish. D., D. W. Dansby. M. P., surface.

87. J. A. Howze, SW NWT $_{4}^{\frac{1}{4}}$ sec. 32 , south of Parrlsh. D., D. W. Dansby. M. P., surface. Tamiami Farms, Tamiami Trail, 3.6 miles northeast of Parrish. D., D. W. Dansby. M. P., top of 3/4-inch plpe over well, same altitude as surface.

89. Tamiami Farms, Tamiami Trail, 3.2 miles north of Parrish. D., D. W. Dansby. M. P., top of well casing, same altitude as surface.

90. Eagle Fruit Co., south of Fort Hamer, sec. 19, T. 34 S., R. 19 E. D., Jim Reddick.

91. Eagle Fruit Co.,' south of Fort Hamer, sec. 19, T. 34 S., R. 19 E. M." F., top of 3/4-1nch pipe on well, 1.5 feet above surface.

92. James L. Waterbury, Taterbury. D, D. T. Dansby.

93. S. R. Mason, west side of road at Mason residence, sec. 7, T. 33 S., R. 18 E. M. P., surface.

Marion County

1. State Road Department, about 1.2 miles west of Flemington, sec. 33, T. 12 S., R. 20 E. M. P., top of $6-1$ inch casing, 6 inches above surface.

2. F. R. Williams, Citra. Hamilton. M. P. top of 6-inch casing, 4 feet below surface.

3. Florlde Power \& Light Co., sec. 32, T. 11 S., R. 24 E. D., E. S. E. D. M. P., top of 4-1nch pipe, 4 feet above surface.

4. Judge Wiley, about $\frac{1}{4}$ mile west of Anthony. M. P., top of 6-1nch casing, 1 foot above surface. U. S. E. D., Sharpes Ferry, sec. 11, T. 15 S., R.'23 E. D., J. S. E. D. M. P., top of 3/4-1nch pipe, 2 feet above surface. 然 5 feet above surface. face.

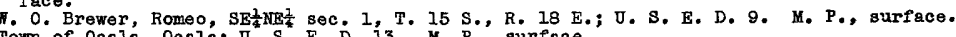

Town of Ocala, Ocala; U. S. E. D. 13 M. P., surface. face.

11. G. A. Zeller, Oklawaha; U. S. E. D. 61. M. P., surface.

12. Weirsdale packing house, Weirsdele; U. S. E. D. 62. M. P., surface.

13. H. B. Wasson, Santos; U. S. F. D. 64. M. P., surface.

14. M. Blackon, Sumerfield; J. S. E. D. 65 . i.' P., surface.

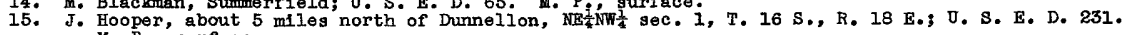
M. P., surface. 
Records of wells in the Florida peningula - Contimued

Owners, location, and drillers of the wells, description of the measuring points, and remarks - Continued

Marion County - Continued

16. J. S. E. D., about 1.3 miles southeast of Dhannellon; U. S. E. D. 363. D., U. S. E. D.

17. U. S. E. Durface about 6 miles east of Dunnelion; U. S. E. D. 367. D., U. S. E. D. M. P., sur-

18. M. O. Jarago, about 3.5 miles west of Martel, NW $\frac{1}{4} N E \frac{1}{4}$ sec. 20, T. 15 S., R. 20 E.; U. S. E. D.

19. W. D. Parker, about 2.5 miles northwest of Leroy, NW $\frac{1}{4}$ NW $\frac{1}{4}$ sec. 30, T. 15 S., R. 20 E.; U. S. E. D? 248. M. P., surface.

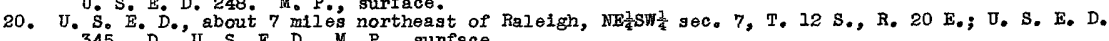
345. D., U. S. E. D. M. P., surface.

21. C. D. Colson, about 3.5 miles east of Williston; U. S. E. D. 320. M. P., surface.

22. J. W. Wilson, Reddick; U. S. E. D. 300. M. P., surface。

23. G. L. Carlton, about 3 miles east of Sparr; U. S. E. D. 310. M. P., gurface.

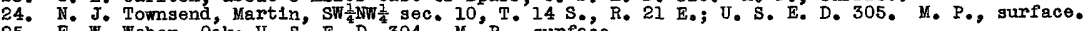

25. F. W. Weber, Oak; U. S. E. D. 304. M. P., surface.

26. Fort McCoy Lumber Co., about is mile west of Fort McCoy; D. S. E. D. 306. M. P., surface.

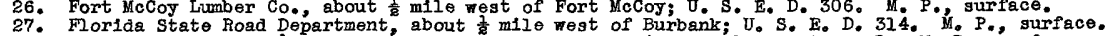

27. Frorida State Road Department, about t mile west of Burbank; U. S. E. D. 3I4. M, P., surface,

29. U. S. E. D., about $\frac{1}{8}$ mile east of Eureka; J. S. E. D: 312. D., U. S. E. D. M. P., sure

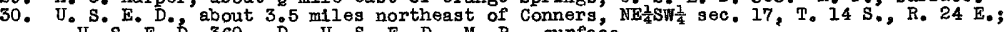

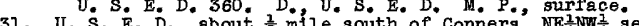

31. U. S. E. D., about $\frac{1}{8}$ mile south of Conners, NE $\frac{1}{4} N W \frac{1}{4}$ sec. 36, T. 14 S., R. 23 E.; U. S. E. D. 359.

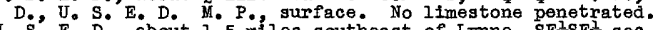

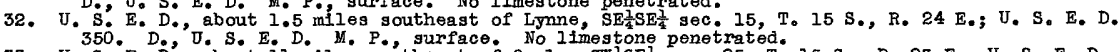

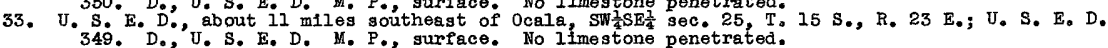

34. C. Wililams, about 0.8 mile northrest of silver Springs; U. $S_{0} E_{.} D_{.} 291$. M. $P_{.}$, surface.

35. T. W. Penuel, bout 1.5 miles south of Silver Springs; U. S. E. D. 292. M. P., surface.

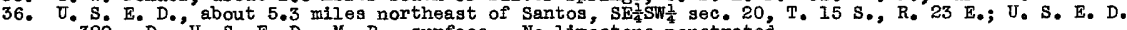
389. D. U. S. E. D. M. P. surface. Ho liméstone penetrated

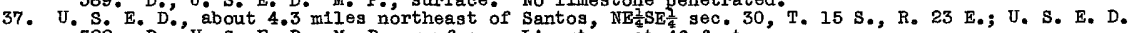
388. D. U. S. E. D. M. P. surefgce. Limestone at 46 feet.

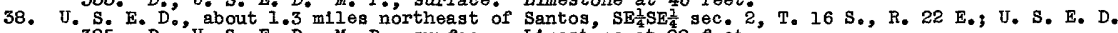
385. D. U, S, E, D, M. P. surface. Limestone at 28 feot.

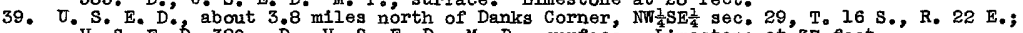

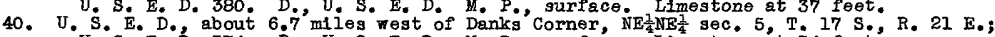

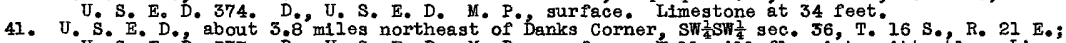
U. S. E. D. 377. D., U. S. E. D. M. P., surface. Well will flow intermittentiy. Limestone at 10 feet.

42. J. S. E. D., about $10 \mathrm{mlles}$ east of Dunnellon, NE $\frac{1}{4} \mathrm{NE} \frac{1}{4}$ sec. 3, T. 17 S., R. 20 E.; U. S. E. D. 37i. D., U. S. E. D. M. P., surface.

43. J. I. Ross, about 1 mile northeast of Stokes Ferry, NE $N E \frac{1}{4}$ sec. 19, T. I7 S., R. 20 E.;

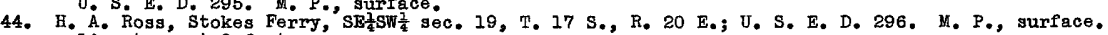
Limestone at 2 feet.

\section{Martin County}

1. J. Zeddingfields, about 6 miles southwest of Stuart, sec., 23, T. 38 S., R. 40 E. M. P., top of $3 / 4$-inch faucet, 2.5 feet above surface.

2. F. A. Harrod, about 6 miles southest of Stuart, sec. 23 , T. 38 S., R. 40 E. M. P., top of $3 \frac{1}{8}-$ Inch valve, 2.5 feet above surface.

3. Brown estate, about l $\frac{1}{2}$ miles west of Stuart. D., Thompson. M. P., top of 3/4-inch pipe, l表 feet above surface.

4. W. O. Carnegie, about $\frac{1}{8}$ mile north of Sewells Point. M. P., top of 4-inch well, 1.5 feet above surface.

\section{Monroe County}

1. S. O. Johnson, Key West, D., J. T. Brown. M. P., top of 24-inch man hole, 0.5 foot above surface.

2. City of Key Hest, Key West.

3. Florida East Coast Railwaj, Marathon Key. D., E. A. Durst. M. P., surface.

\section{Nassau County}

1. A. E. Carlton, Kings Ferry. M. P., top of $3 / 4$-inch faucet, 3.5 feet above surface.

Dixle Turpentine Still, Leislie, sec. 2, T. 3 N., R. 25 E. M. P. t top of 3/4-inch pipe, 1 foot above surface.

3. L. R. Owens, about 2 milen southeast of Leslle, sec. 5, T. 3 N., R. 26 E. M. P., top of 3/4-inch pipe, 1 foot aliove surface.

4. Gross Thurpentine Co., Grots. M. P., top of 1-inch pipe, 1 foot above surface.

5. L. A. Davis \& Bros," Cranclajl. D.' Stafford. M. P., top of pipe, 2 feet above surface.

6. Southern States Power Co. Fernandina. M. P., top of pipe, 3 feet above surface.

7. Town of Fermandina, Fermailina Beach. M. P., top of 3-inch valve, 2 feet above surface.

8. H. F. Sahlman, about 1 mile south of Amelia. D., Freeman, M. P., top of 3/4-inch plpe, 1 foot above surface.

9. S. A. I., Yulee. M. P., tiop of water tank, 26 feet above surface.

Flood, Yulee. D., W. Dukes. M. P., top of 3/4-inch pipe, 3 feet above surface.

11. Davis \& Son, Yulee. D., llorror. M. P., top of $\frac{1}{8-1}$ inch pipe, 3 feet above surface.

12. Shave \& Powell, Italla:" II. P., top of 3 -inch casing, 2 feet above surface. J. C. P1ttman, about 3.5 niles' northeast of Callehan. D., W. Dukes. M. P., top of $3 / 4-$ inch

14. Wells \& Wells, Callahan. D., H. C. Russell. M. P., top of $3 / 4-$ inch faucet, 1 foot above surface.

15. C. C. Jones, Callahan. M, P., surface.

16. J. J. O'Connor, Callahan. M. P., top of theh plpe, 1 foot above surface.

17. Bob Wright, Crawford. M. P., top of $1 \frac{1}{4}-$ inch pipe, 5 feet above surface.

18. Bryce, Verdie. M. P. toj of $1 \frac{1}{2}$ inch well coupling, 6 inches above surface.

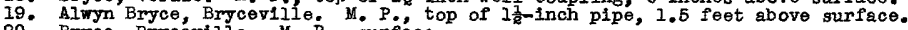

20. Bryce, Bryceville. M. P. surfíce.

21. Mrs. Ruth Bryce, about 1 julle south of Bryceville, M, P. surface. 
Records of wells in the Florida peninsula - Continued Owners, location, and drillers of the wells, description of the measuring points,
and remarks - Contimued

Okeechobee County 1. Town of okeechobee, Okeechobee. M. ${ }^{2}$, top of $3 / 4$-inch pipe, 1 foot above surface. Original
depth 810 feet. Measured depth in 1933 was 718 feet.

Orange County

1. City of Orlando, Orlando, Evans Ave, 100 feet west of Orange Ave. D., J. R. Matthews.

M. P., north side of steel rim of manhole over well, same altitude as surface of street.

2. City of Orlando, Orlando, Winter Park Ave., 200 feet west of Orange Ave. D., J. R. Matthews.

3. City of ' north side of steel rim of manhole over well, same altitude as surface of street.

City of Orlando, Orlando, Dade St., 100 feet north of Princeton Ave. D., F. J. Raehn.

M. P. north side of steel rim of manhole over well, same altitude as surface of street.
4. city of Orlando, Orlando, W. South St. and Garlend St. M. P., south side of rim of manhole over well, same altitude as sidewalk.

5. City of Orlando, southwest corner of Drvision and Carter Sts., Orlando, D., F. J. Raehn. x. P., north side of steel rim of manhole over well, same altitude as surface.

6. City of' Orlando, Parramore St. 100 feet north of Long'st., Orlando, D., F. J. Raehn. M. P., north side of steel rim of manhole over well, same altitude as surface.

7. City of Orlando, northeast corner of Gore Ave, and Parramore St., Orlando. M. P., steel rim of manhole over well, same altitude as surface.

8. City of Orlando, northwest of Intersection of Kentucky Ave. and West Washington St., Orlando. M. P., north side of steel rim of manhole, same altitude as surface.

9. City of' Orlando, south side of Lake Davis bétween Brooksvilla and Summerlin Sts., Orlando. 14. P., top of 8 -inch casing of well.

10. City of' Orlando, southeast edge of Cherokee Lake, Cherokee Drive and Osceola St., Orlando. M. P., steel rim of manhole over well, same altitude as surface.

11. city of Orlando, north side of Delaney Śt. at E. Harding Ave., Oriando. D., F. J. Raehn. Y. P., steel rim of manhole over weil, same altitude as surface.

12. Citj of' Orlando, Orlando, northrest edge of Lake Davis, D., Henry Raehn. M. P., surface.

13. City of Orlando, Orlando, Boston Ave, and Long St, D., Henry Raehn. M. P., surface.

14. City of Orlando, Orlando, Princeton Ave. and Northumberland St. M. P., surface.

15. City of Orlando, Oxlando, Comell St. and Spruce Ave. H. P., surface."

16. City of Orlando, Orlando, P1ne St. and Eola Drive. D., F. J.'. Raehn. M. P., surface.

17. City of Orlando, Orlando, on Lake Formosa. D. J. R. Matthews. M. P., surface.

18. City of Orlando, Orlando, Lake of the Woods. B., F. J. Raehn. M. P., surface.

19. City of Orlando, Orlando, South St. and Ferm Creek. M. P., surface.

20. City of Orlando, Orlando, Spokane $\mathrm{St}$. and Oregon Ave. D., F. J. Raehn. M. P., surface.

21. City of Orlando, Orlando, South St. between Ohio St. and Texas Ave., at Lake súnset. D., F. J. Raehn. M. P., surface.

22. City of Orlando, Orlando, east side of Lake Lancaster. D., F. J. Raehn, M. P., surface.

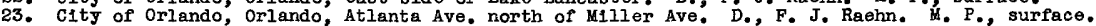

24. City of Orlando, Orlando; McRae St. between Evans and King Aves, D., J. R. Matthews. M. P., surface.

25. City of' Orlando, Orlando, Terry and Jefferson Sts, M. P. surface.

26. City of Orlando, Orlando, Harrison St. 500 feet south of Par Ave. D., J. R. Matthews. M. P., surface.

27. City of'Orlando, Orlando, Shine and Marks Sts. D., F. J. Raehn. M. P., surface.

28. City of Orlando, Orlando, Intersection of Killer and Minnesota Aves. D., F. J. Raehn. M. P., surface.

29. City of' Orlando, Orlando, Helen St. D., J. R. Katthews. M. P., surface. 30. City of Orlando, Orlando, Westmoreland Drive and Jefferson St.' D., F. J. Raehn. M. P., sur-

31. City of Orlando, Orlando, Sturdevant st, and Lucerne Terrace. D., F. J. Raehn. M. P., surface.

32. City of Orlando, Orlando, Lake Davis. D., F. J. Raehn. M. P. surface.

34. City of Orlando, Orlando, Yale Ave, and Westmoreland Drive, D., J. R. Matthews. M. P., surface.

35. Orange County, county well l, I mile west of Pinecastle, on north side of road in ditch, south-

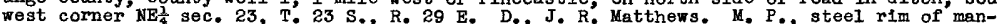
hole over well, same altitude as surface of road.

36. Orange Gounty, county well 2 , about $1 \frac{1}{2}$ miles southwest of Pinecastle, in ditch on south side of road, NW $\frac{1}{4}$ NH $\frac{1}{4}$ sec. 26, T. 23 S., R. 29 E. D., J. R. Mathers, M. P., steel rim of man-

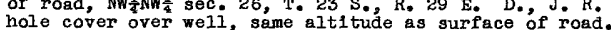

37. Orange Gounty, county well 3 , about 2 miles southwest of Pinecastle, in ditch on south side of road, NW $\frac{1}{4} N \frac{1}{4}$ sec. 27, T. 23 S., R. 29 E. D., J. R. Matthews. M. P., steel rim of manhole over well, same altitude as surface of road.

38. Orange County, county well 4 , about $\frac{1}{8}$ mile west of Orlando clty limits, in ditch on west side

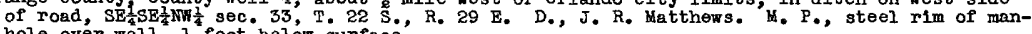
hole over well, 1 foot below surface.

39. Orange County, county well 5, about $4 \mathrm{mlleg}$ southwest of 0rlando, in drainage ditch at edge of swamp east of highway, $\mathrm{SE}_{4}^{\frac{1}{4} \mathrm{SE}_{4} \mathrm{SE}_{4}^{2}}$ sec. 8, T. $23 \mathrm{~S}, \mathrm{R}_{0}, 29 \mathrm{E}$. D., J. R. Matthews. M. P., rim of manhole over well, 4 feet above surface and top of well casing.

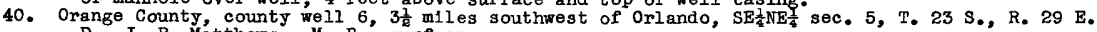
D., J. R. Mát thews. M. P., surface.

41. Orange County, county weil 'i', about 2 miles south of Pinecastle on north side of road and south

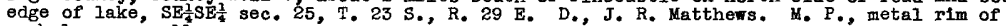

manhole over well.

42. Orange County, county well 8, about $1 \frac{1}{\mathrm{z}} \mathrm{miles}$ east of Conway, west side of road on east side of

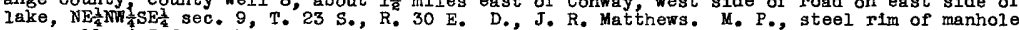
over well, 4.5 feet above surface.

43. Orange County, county well 9 , about 0.2 mile north of Conway, west side of road, NE $\frac{1}{4} N W \frac{2}{4} N E \frac{1}{4}$ sec. 8, T. 23 S., R. 30 E. D., R. L. Smith. H. P., steel' rim of manhole over well, same altitude as surface of road.

44. Orange county, county well 10, about 3 miles southwest of Orlando, in drainage ditch east of road and on west side of swamp, SE $\frac{2}{4} \mathrm{NE} \frac{1}{4} \mathrm{NE} \frac{2}{4}$ sec. 8, T. 23 S., R. 29 E. D., J. R. Hatthews. M. P., top of manhole over weli, same altitude as surface of road.

45. Orange County, county well 11 , about $1 \frac{1}{2}$ miles northeast of Conway, on line of $N F \frac{2}{4} \mathrm{NW} \frac{1}{4} \mathrm{sec}$. 9 , T. 23 S., R: $30 \mathrm{E}$. D., R. L. Sinth. M. P., surface.

46. Orange county county weil i2, about $5 \mathrm{mlies}$ southeast of Orlando, at residence on north side

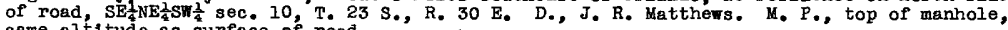
same altitude as surface of road.

47. Orange County, county well 13, about 2 miles northwest of orlo Vista, in sink on west side of

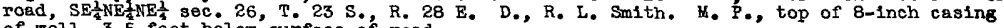
of well, 3.5 reet below' surface of road.

48. Orange County, county well 14 , about 1.5 miles west of 0rlando city limits, in ditch on west

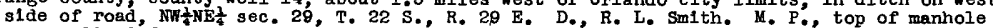
over well, 2 feet below surface of road. 
Records of wells in the Florida peninsula - Continued.

Owners, location, and drillers of the wells, description of the measuring points, and remarks - Contimued

Orange County - Continued

49. Orange County, county well 15 , about 2 miles southeast of Orlando, KF $\frac{1}{4} \mathrm{NE}_{4}^{\frac{1}{4}}$ sec. 5, T. 23 S., R. 30 B. D., R. L. Smith. M. P., surface.

50. Orange county, county well 16, 4 miles northeast of Orlo Vista, $\mathbf{S w} \frac{1}{4} \operatorname{Sw} \frac{1}{4} \mathrm{NE} \frac{2}{4} \mathrm{sec} .20, \mathrm{~T} .22 \mathrm{~S}$. R. 29 B. D., J. R. Matthews. M. $P_{\bullet}$, surface.

51. Orange County, county well 17, about $i$ mile west of Fairvilla, in ditch on north side of road,

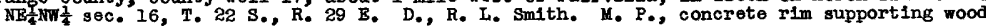
manhole cover over well"' 2 feet below surface of road.

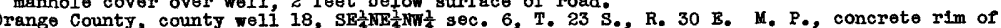
manhole, game altitude as road surface.

53. Orange County, county well 19, about 1 mile west of Fairvilia, in ditch on north side of road

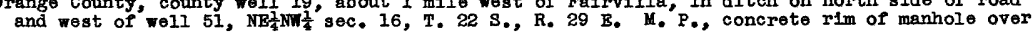

54. Town of Winter Park, Winter Park, southeast corner Center st, and WeIborne Ave. D., W. A. Neal. M. P., steel rim of manhole over well, same altitude as sidewalk.

55. Orange County, about 1 mile west of Maitiand, on north shore of Lake Syb1Ila. M, P., steel rim of manhole over well, same altitude as surface.

56. Town of Apopka, Apopkr, east slde of Highland Ave. 200 feet north of 4 th st. M. R., steel rim of manhole over vell' same altitude as surface.

57. J. B. Jackson, east shore of Lake Apopka at Flsherman's Paradise, sec. 30, T. 2I S., R. 28 B. D. R. I. Sinth. M. P., top of 4-inch well casing, same altitude as surface.

58. Harold Tllden, south end of Lake Apopka, in orange grove Just west of old Winter Garden Docks.

59. R. I. Silth, east of Sinith residence, Oakland. D., R. L. Smith. M. P., top of concrete wall, 7.45 feet above top of well casing and about same altitude as surface.'

60. H. C. TIIden, about 2 miles east of Winter Garden and mile south of winter Garden road,

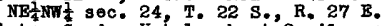

61. Winter Garden Hotel, about 2 miles east of finter Garden, in field on south side of road. M. P., top of concrete wall on south side of well, 8.5 fest above top of casing.

62. T. F. Bénnett, about 1 mile northeast of Vineland on west shore of B1g Sand Lake, sec. 11, T. 24 S., R. 28 E. M. P., top of concrete manhole over well, same altitude as surface.

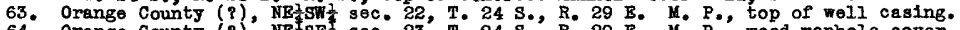

64. Orange County (?); HE SSE sec, 23, T. 24 S., R. 29 E. M. P., mood manhole cover, 4.35 reot above top of weil casing.

65. Tom of Bithlo, Bithlo. Ki. P., top of concrete rim around well pit, 3 feet above surface.

66. About 1.5 miles east of Fort Christmas, on south side of road, NW $\frac{1}{4}$ sec. $35, T .22 \mathrm{~S} ., R_{0}$. 33 B. M. P., top of 2-1nch pipe on well, I foot above surface.

Osceola County

1. S. G. Sligh, about 1.5 miles northeast of Loughman. D., Jim Dribble. M. P., top of 4-1nch

2. Gilbert Park, Gilbert Park, about I mile southwest of K1ssimmee. D., Jim Dribble. M. R., conm crete rim of pool, 5 feet above surface.

3. A. P. Tate, about 1 mile southwest of K1ssimmee. M. P., top of 2-Inch pipo, I foot above surface.

4. Kissimee. M. P., surface.

5. KIssimmee. M. P., surface.

6. St. Cloud. M. P., surface.

7. St. Cloud. M. P., surface.

8. G. M. Griffin, Holopaw. M. R., surface.

Palm Beach County

1. Hulls Grove, about 6 miles west of Jupiter. M. P., top of 2-inch well casing, 1.5 feet above surface.

2. Seminole Golf Course, Juplter. D., R. F. Hair. M. R., pump-house floor, 1 foot above surface.

3. Seminole Golf Course, Jupiter. D., R. F. Halr. M. P., top of 6-inch weil casing, 1.5 feet above surface.

4. Fiorida Power \& IIght Co., West Palm Beach. D., Layne Southeastern Co. M, $P_{*}$, top of $\frac{2}{4}-1$ inch valve on pump, 2 feet above surface.

5. Florida Power \&c Iight Co., West Palm Beach. D., R. F. Hair. M. P., surface.

7. Tom of Lake Worth, Lake Worth. D., Gray. M, P., surface.

8. Colonel Bresford, ebout 1 mile east of"Lantana, sec. 3, T. 45 S., R. 43 E. D., R. F. Halr. H. R., surface.

9. Tom of Boca Raton, Boca Raton, M. P., surface.

10. Experiment Station, Florida University', Everglades Experiment Station, near Belle Glade. D., Gray Artesian Well Co, M. P., top of plpe, 3 feet above surface.

11. 0. S.' Sugar Corporation, swi sec. i2, T. $42 \mathrm{~S}$, , R. $18 \mathrm{E}$., south side of conners highway and 3 miles southeast of Canal Point. " $K_{0} P_{*}$, top of 6-1nch pipo, 2 feot above surface.

\section{Pasco County}

1. Cummer Cypress Lumber Co., Lacoocheo. M. P., top of 6-Inch casing, 0.3 foot above surface. 2. Aripeks lumber Co., about $1 / 8$ mile southeast' of Pivay. M. P., top of 8 -inch well casing,

3. Fivay School, Fivay Junction. D., C. Glass. M. P., top of It-inch casing, 4 feet above sur-

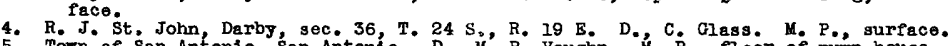

5. Town of San Antonio, San Antonio. D., M. R. Vaughn. 'M. P., floor of pump house, 1 foot above surface.

5. Joo Bartel, San Antonio. M. P., pump bese, 2 feet above surface.

7. St. Leo's School, about $\frac{2}{4}$ mile south of St. Leo. M. P., floor of pump house, I foot above surface.

8. Town of Dade City, Dade City. M. P., surface.

9. Ice plant, Tampe kloctric Co., about' $\frac{1}{2}$ mile north of Dade C1ty. M. P., top of 6-inch tee, 1.5 foet above surface.

10. Ice plant, Tampa Blectric Co., about $\frac{1}{2}$ mile north of Dade City. M. P., top of 6-1nch casing, 4.5 feet below surface.

11. W. A. LaHeup, sec. 16, T. 25 S., R. 21 E., LaHeup H1ll. M. P., pump base, I foot above surface.

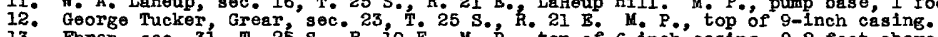

13. Ehren, sec. 3i, T. 25 S., R. ig B. M. P. top of 6-inch casing, 0.8 foot above surface.

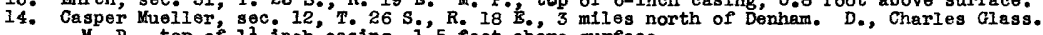
M. P., top of iz-inch casing, i.5 feet above surface.

15. Westley Chapel School, sec. 8, T. $26 \mathrm{~S}_{*}, \mathrm{R}, 20 \mathrm{E}$, , about 9 miles northeast or Denham. D., Charles Glass. M. P., top of iz-1nch' casing, í.5 feet above surface. 
Records of wells in the Florida peninsula - Continued

Owners, location, and drillers of the wells, description of the measuring points, and remarks - Continued

Pasco County - Continued

16. P. C. Pobb, about 2 miles north of Zephyr Hills. D., M. R. Vaughn. M. P., surface.

17. S. E. Reecker, about 2 miles north of Zephyr Hilis." D., May Bros. M. P." surface.

17. S. E. Reecker, about 2 miles north of Zephyr Hills.

19. Town of New Port Richey, New Port Richey. 'M. P., surface.

20. Town of Elfers, Elfers. M. P., surface.

\section{Pinellas County}

1. Gity of St. Petersburg, clty well 7, Mirror Lake Dr1ve on west side of M1rror Lake, st. Petersburg. M. P., top of well caling, same altitude as surface.

2. City of St. Petersburg, c1ty well 8 , Mirror Lake Drive on west side of Mirror Lake, St. Petersburg. M. P., top of concrete rim of base of pump house, same altitude as surface.

3. City of st. Petersburg, c1ty well 9 , Mirror Lake Drive, north side of Mirror Lake, St. petersburg. M. P., top of concrete rim of base of pump house, same altitude as surface, 2.3 feet above top' of casing

4. Don-Ce-Sar Hotel, Pass-a-Grilie Beach, at Don-Ce-Sar Hotel. M. P., top of 4-1nch p1pe, 2 feet above surfece.

5. City of Clearmater, c1ty well 12, east of Stephenson Creek and north of Cleveland St., Clearwater. M. P. top of well casing.

6. City of clearwater, city well 13, Park St, and Missourl Ave, Clearwater. M. P., surface.

7. City of Glearwater, c1ty well 11, Cleveland St, and Missouri' Ave., Clearwater. M. P., surface.

Polk County

1. Speth Grove, about 3.5 miles northesst or Kathleen, sec. 8, T. 27 S., R. 23 E. D., R. Meikirk. M. $P .$, pump base, at surface. Durlng construction of well driller reported water level 40 feet below surface unt1l he reached rock at 138 feet; then water level stood 78 feet below surface.

2. Town of Polk City, Polk C1ty. D., H. Chase. M. P., top of 8-inch casing, I foot above surm Pace.

3. Everglades Cypress Iumber Co., Loughman. M. P., top of 6-inch tee, 1.5 feet above surface.

4. H. E. Strohme, about $2 \frac{1}{2}$ miles northwest of Davenport. D., J. B. Whatley. M. P., top of 6-inch plpe, 3 feet sbove surface.

5. Town of Davenport, Davenport. M. P., pump base, same altitude as surface.

6. Town of Halnes city, Haines city. D., Perry Bros. M. P., top of well p1t, 1 foot above surface.

7. Town of Haines Clty, Haines C1ty. D., Perry Bros. M. P., top of 3/4-1nch plug in 6-1nch ell, 5.6 feet below surface.

8. A. C. L., Halnes City. M. P., top of 6 -inch casing, 12 feet below surface.

9. Federal Ice Co., Lakeland. D., Ohlo Well Drilling Co. M. P., surface.

11. Southern Utilities Co. 1ce plant, North Dakota'st. and rallroad, Lakeland. D., H1l11ard. H. P., top of 1-inch plug in 8-inch casing, 3 feet above surface.

12. Town of Lakeland, Lakeland. D., G. Southard. M. P., pump base, at surface.

13. Town of Lakeland, Lakeland. D., R. Ne1kirk. M. P., pump base, 1 foot below surface.

14. Town of Auburndale, Auburndale. M. P., surface. above surface.

16. Town of Lake Alfred, Lake Alfred. D*, J. B. Whatley. M. P., top of 10-inch casing, 12.4 feet below surface.

17. C. D. Page, sec. 24, T. 28 S., R. 25 E., about 3 miles northwegt of Winter Haven. M. P., top of stone wall at veli, 6 inches above' surface.

18. Yates, about 3 miles northwest of Winter Heven. M. P., top of 5-inch casing, 2 feet below surface.

19. Town of Winter Haven, Florence Villa. M. P., top of 6-inch casing, 7 feet below surface.

20. Town of Winter Haven, winter Haven. M. P., top of 10-inch casing, 13 feet below surface.

21. Town of Winter Haven, Winter Haven. M. P.; top of 12-inch casing, 6 inches below surface.

22. Town of Eagle Lake, Eagle Lake. D., T. S. Whatley. M. P., pump base, at surface.

23. Town of Lake Hamilton, Lake Hamiltón. M. P., top of 6-inch casing, 6 ' inches above pump-house Ploor and surface.

24. International Agricultural Chemlcal Phosphate Co., well 3, about 2 miles west of Mulberry. M. P., top of 10-inch casing, 1 foot below surface.

25. International Agrecultural Chemical Phosphate Co., well 2, about 2 miles west of Mulberry. M. P., top of $2 \frac{1}{2}-1$ nch tee on top of $10-1$ inch casing, 3 feet above surface.

26. International Agricultural Chemical Phosphate Co., well 1 , about 2 miles west of Mulberry. M. P., top of 10-inch casing, 0.5 foot above surface.

27. Florida' Phosphate Co., International Agricultural Chemical Phosphate Co. well 23, about 1 mile east of Mulberry. M. P., top of 12 -inch casing, 1 foot above surface.

28. A. B. McLain, about $3 \mathrm{mjles}$ northwest of Bartow, sec. 36, T. $29 \mathrm{~S}$., R. 24 E. D., T. S. Whatley. M. P., top of 6-inch casing, 0.7 foot above surface.

29. Frost \& Harper, about 2.5 miles northrest of Bertow. M. P. surface.

30. Armour Fertilizer Co., about $1.5 \mathrm{mlles}$ west of Bartow. D., Bóland. M. P., floor of englne rour Fertilizer co., about

31. Town of Bartow, Bartow. D., Virginia Machinery \& Well Drilling Co. M. P., surface.

32. Mountaln Lake Corporation, well 1 , about 2 miles north of Lake Wales. M. P., pump base, 3 feet below surface.

33. Mountain Lake Corporation, well 2, about 2 miles north of Lake Wales. M. P., pump base, 6 feet below surface.

34. Florida Public Service Co., Lake Wales. D., R. J. Weikirk. M. P., top of 12-inch casing, 5.5 feet below surface.

35. American Agricultural Chemical Co., well 6, sec. 31, T. 30 S., R. 24 E., P1erce. M. P., top of $30-1$ ch casing, I foot above surfece.

36. Amalgamated Phosphate Co., Brewster. M. P., top of 15-inch casing, 1 foot above surface.

37. Amal gamated Phosphate Co. Brewster. M. Po top of 18 -inch cesing 7 feet above surface

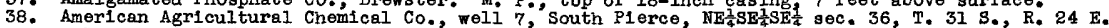
D., Virginia Machinery \& Well Drililing Co. M. P., top of 30-inch casing, st surface.

39. K. $\mathrm{O}_{\text {. Varmes, about } 1 \text { mile northeast of Fort Meade. D., C. M. Bolend. M. P., top of } 4-1 \text { inch }}$ pipe, 3 feet above surface.

40. About 2 miles west of Fort Meade. M. P., top of 3/4-inch faucet 6 inches above surface, at gasoline station.

41. Town of Frostproof, Frostproof. M. P., top of 3/4-inch valve on top of $12-1$ inch casing, 1 foot above surface.

42. Town of Fort Meade, Fort Meade. M. P., surface. 
Records of wells in the Florida peningula -. Continued

Owners, location, and drillers of the wells, description of the measuring points, and remarks - Continued

Putnam County

1. P. D. Watking, sec. 1, T. 9 S., R. 23 E., Putnem Hall. M. P., top of $2 \frac{1}{2}-1$ inch casing, 2.5 feet above surface.

2. R. J. Hancock, about 1.2 miles north of Bostw1ck, sec. 19, T. 8 S., R. 27 E. D., Ralph W1ll1s. M. $P$, top of 4-inch well tee, 1.5 feet above surface.

3. R. J. Hancock, Bostwick. M. P., surface.

4. R. W. Vames, about 1 mile south of Bostrick. D., Ace. M. P., top of $3 / 4-1$ nch faucet, I foot above surfece.

5. E. J. Cameron, about 1 mile south of Bostwick. M. P., top of 4-1nch casing, 0.5 foot above surface.

6. Appleby's dalry, about 4 miles south of Bostwick. M. P., top of 4-inch casing, 3 feet above surface

7. W. R. Seliards, about 1 mile south of Federal Point. D., Ed Benedict. M. P., top of 3/4-1nch faucet at weil, 2 feet above surface.

8. Esperanto-Grove Winnemesset Park Go., about 3 miles north of East Palatka. M. P., top of 3/4-1nch faucet, 2 feet above surface.

9. Esperanto-Grove Winnemesset Park Co., about 3 miles north of East Palatka. D., Ed Benedict. M. P., top of $\frac{1}{2}$-inch faucet on lock, 3 feet above surface.

10. J. C. Tomsend, Orange Mills. D., N. H. Monck. M. P., top of 3/4-1nch faucet, 2 feet above surface.

11. Louls Broer, East Palatka, near A. C. L. station. M. P., top of 3/4-1nch faucet, 2 feet above surface.

12. Town of Palatka, Palatka. M. P., top of 3/4-1nch faucet, 1 foot above surface.

13. Rheads, laurel and 2d Sts., Palatka. M. P., top of 3/4-inch faucst, I foot above surface.

14. Town of Interlachen, Interíachen. D., Layne Southeasterm Co. M. P., pump base, at surface.

15. A. C. I., sec. 27, T. $10 \mathrm{~S}, \mathrm{R}_{.} 26 \mathrm{E}$., St. Johns River and railroad bridge. D., J. Mervin. A. C. L., sec, 27 , T. 10 S, R. 26 E., St. Johns River and rallroad bridge. D., J. Mervin. M. P., top of lin-1nch valve, in south house on bridge.

16. George Wangbickler, Saratoga Landing, T. 11 S., R. 26 E. M. P., top of 3/4-inch faucet near dock, 0.5 foot above surface.

17. Florlda State Road Department, east side of Dunns Creek Bridge and north side of highway south-

18. F. Board, about 1 mile north of Welaka, sec. 33 , T. 11 S., R. 26 E. D., Ed Benedict. M. P., top of 2-1nch casting, 0.5 foot above surface.

19. Mrs. B. Hayes, Pomona. M. P., top of 2 -inch casing, 1.5 feet below surface.

21. Blanchard, about 2 miles south of Georgetown on Lake George. M. P., top of $3 \frac{1}{2}-1$ ch casing, 1 foot above surface.

22. William McElroy, about $\frac{1}{2}$ mile north of boat landing on Drayton Island. M. P., surface.

23. H. Rehberg, about $\frac{7}{4} \mathrm{mlle}$ south of boat landing on Drayt on Island. M. P., on $3 / 4-1$ nch faucet, 1 foot above surface.

24. Town of Crescent City, Crescent C1ty. M. P., top of 6-inch valve at well, 6 inches above surface.

25. Florlda State F1sh Hatchery, near Welaka. D., J. W. Hurst. M. P., top of casing, 6 inches above surface.

26. Florida State Fish Hatchery, near Welaka. D., J. W. Hurgt. M. P., top of casing, 1.5 feet above surface.

st. Johng County

1. G. H. Hodges, about 1 mile north of Swltzerland, sec. 6, T. 5 S., R. 26 E. M. P., top of $3 / 4$-inch faucet, 2 feet above surface.

2. G. H. KIIngberg, about $\frac{1}{4}$ mlle west of Switzerland. M. P., top of 6-inch casing, 1 foot above surface.

3. Frank Hale, sec. 35, T. 4 S., R. 27 F., about 5 mlles southwest of Bayard. D., Shaeffer. M. P., top of 6 -inch plpe, 2 feet above surface.

4. St. Johns race track, sec. 4, T. 5 S., R. 28 E., south of Bajard. M. P., top of 6-inch valve, i foot above surface.

5. St. Johns race track, sec. 4, T. 5 S., R. 28 E., near race track. M. P., top of 6-inch valve, at surface

6. Mrg. E. Mickier, about 3 miles southeast of Palm Valley. D., H. Walker. M. P., top of 4-1nch

7. George oesterricker, Ganal drawbriage, sec. 28, T. 4 S., R. 29 E. D., Gray. M. P., top of 3/4-1nch plpe, 2 feet above surface.

8. Florida State Road Department, about 7 miles north of Vilano Beach. M. P., top of 3/4-1nch pipe, 3 feet above surface.

9. Florlda State Road Department, about 12 miles north of Vilano Beach. M. P., top of $3 / 4-1$ nch pipe, 4 feet above surface.

10. Mill Creek School, about 9 miles east of Strands Bridge, sec. 20, T. 6 S., R. 28 E. M. P., top of $3 / 4$-inch plpe, 2 feet above surface.

11. Riverdale Land Go., Riverdale, D., R. C. Walker. M. P., top of 3/4-inch pipe, at surface

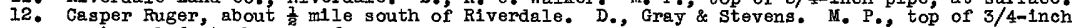
pipe, 1 foot above surface.

13. Sam Altavilia, about li miles south of Riverdale. D., Gray \& Stevens. M. P., top of 3/4-inch

14. F. Ogina, about 2 miles north of vilano Beach. D., Call. M. P., top of 3/4-inch pipe at house, 1 foot above surface.

15. P. J. Manucy, sec. B, T. 7 S., R. 30 E。, Vilano Bridge on North Rlver. M. P., top of 3/4-inch faucet, 2.5 feet above surface.

16. Mrs. J. M. Midaleton. Elkton. D, Walker. M. P., top of 3/4-inch faucet, 1 foot above surface.

17. F. D. Wattels, Anastasia Island, ióo jards west of' st. Augustine Beach. D., Charles Mervin. M. P., top of 3/4-1nch faucet, 1 foot above surface. 18. Mrs. F.' Vail, sec. 8, T. B S., R. $30 \mathrm{E}$. , Moultrie Creek and Matanzas River. M. P., top of

19. V. J. Mlckler, about 1.5 miles north of Crescent Beach. D., V. J. Mickler. M. P., top of 4-Inch tee, 1 foot above surface.

20. W. A. Cubbedge, Crescent Beach. D., Gray \& Stevens. M. P., top of 4-inch tee, 2.5 feet above surface.

21. Corbet estate, Matanzas Inlet. D., H. Walker. M. P., top of 4-1nch valve, 3 feet above surface.

22. F. Rawson, about 3 mlles northwest of Hastings, D., Ed Benedict. M. P., top of 3/4-inch faucet, I foot above surface.

23. J. B. MoCollum, about 2 miles northwest of Hastings. D., Ed Benedict. M. P., top of 3/4-inch faucet, 1 foot above surface.

24. J. J. Brown, Hastings, D., J. W1lson. M. P., top of 3/4-1nch faucet, 1.5 feet above surface.

25. Fannie K. Stewart, Hastings. M. P., top of $3 / 4-1$ inch faucet, 1.5 feet above surface.

26. A. C. Gray, 24 Grant St., St. Augustine. D., A. C. Gray. M. P., top of 3/4-inch pipe, 3 feet above surface.

27. Ponce De Leon Hotel, St. Augustine. M. P., top of 3/4-1nch p1pe, 4 feet above surface.

28. City of st. Augustine, well 2 , St. Augustine. M. P., surface. 

Owners, location, and drillers of the wells, description of the measuring points,
and remarks - Continued

St. Iucle County

1. Ifunicipal plant, Fort Plerce. M. P., top of 3/4-inch valve at 4-inch well tee, 2.5 feet above surface.

2. Floyd Johnson, about 9 miles west of Fort Pierce, sec. 32, T. 35 S., R. 39 E. D., Floyd Johnson. M. P.; top of 3 -inch pipe, 1.5 feet above surface.

3. J. W. Shipe, about $3.7 \mathrm{miles}$ west of Fort Pierce railroad station, south side of highway. M. P., top of 4-1nch outlet, 1 foot above surface.

Sarasota County

1. Town of Sarasota west well at clty plant, North Orange Ave., Sarasota. D., C. L. Thompson. K. P., top of 1 -inch outlet on top of pum, same altitude as surface. Analjsis of water included in Sarasota report.

2. Town of Sarasota, East Chester Drive, Sapphire Heights, Sarasota; well 4 of Sarasota report. D., C. L. Thompson. M. P., top of $\frac{2}{4}$-1nch pipe on pump, 3.2 feet above surface. Analysis of water included in Sarasota report.

3. Town of Sarasota, south of Ringling circus quarters, Sarasota; well 5 of Sarasota report. D., C. L. Thompson. M. P., top of 3/4-1nch pipe, 4 feet above surface. Analysis of water included in Sarasota report.

4. Ringling estate, west of Bird Bey on Ringling causeway, Sarasota; well 28 of Sarasota report. D., W. Adams. M. P., top of 3/4-inch pipe, 3 feet above surface. Analysis of water included in Sarasota report.

5. R. M. Canty, about 12 miles east of Sarasota, in sec. 19, T. 36 S., R. 20 E.; well 46 of Sarasota report. M. P., top of casing, I foot above surface.

6. City water plant, Venice; well 54 of Sarasota report. M. P., top of 3/4-1nch p1pe, 2 feet above surface. Analyses of water included in Sarasota report.

7. Palmer Corporation, sec. 23, T. $36 \mathrm{~S} ., R_{.} 18 \mathrm{E}$. , Palmer Parms; well p-1 of Sarasota report. D., C. L. Thompson. M. P., top of 3/4-1nch pipe, same altitude as surface.

8. Beli' Bros., sec. 30, T. 36 S., R. 19 E., Palmer Farms; well P-19 of Sarasota report. D., C. L. Thompson. M. P., top of valve stem on west outlet at pump house, 1.5 feet above surface. Thompson. M. P., top of valve stem on west outlet at pump house, 1.5 feet above surface.

9. Palmer Corporation, sec. 20, T. 36 S., R. 19 E., Palmer Parms; well P-100 of Sarasota report. D., C. L. Thompson.

Seminole county

1. Seminole County (?), Sw $\frac{1}{4}$ sec. 21, T. 20 S., R. 30 E., on west side of road to Lake Mary. M. P.. top of 2 -inch casing, same altitude as surfáce.

2. J. D. Wicks, sw $\frac{1}{4}$ sec. $35, T$, $20 \mathrm{~S}, \mathrm{R}_{0} 30 \mathrm{E}$, , on south side of road about $0.4 \mathrm{msle}$ west of Wagner. D., M, E. Milier. M. P., top of 3-inch pipe, 1 foot above surface.

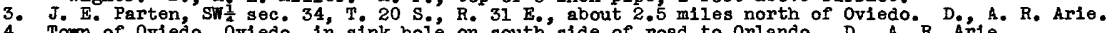
Town of Oviedo, Oviedo, in sink hole on south'side of roed to Orlando. D. A. R. Arile. M. P., top of 4-inch casing, same altitude as surface of ground in sink hole and 10 feet be10\% surface of road.

5. One mile north of Oviedo along Sanford road, on east side of road. M. P., top of 3-1nch casing,

6. Alex Leinhart, swr silace. 34, T. 20 S., R. 31 E., about 2 miles north of oviedo. D., McCollough. M. P., top of 2-inch pipe, i foot above surface.

8. A. R. Arie, about $0.2 \mathrm{mlle}$ north of Oviedo, at Arie residence. D., A. R. Arie. M. P., top of 6 -inch casing, 1.4 feet above surface.

9. C. F. Flesher, about 0.2 mile north of Oviedo, at Flesher residence. M. P., top of $2-1$ ch pipe, same altitude as surface.

10. SE $\frac{1}{4}$ sec. 4, T. $21 \mathrm{~S}, \mathrm{R}_{\text {. }} 31 \mathrm{E}$, , north side of road $0.7 \mathrm{mlle}$ west of turn in road to Sanford. M. P., top of $2-1$ inch pipe, 1.5 feet above surface.

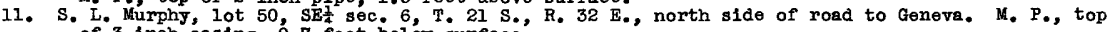
of 3-inch casing, 0.7 foot below surface.

12. Luther Mills, lot 2 , NE $\frac{\lambda}{4}$ sec. 12, T. 21 S., R. 31 E., north side of Geneva road west of Varnsdale st. M.'P,, top of 2 -inch pipe, 2 feet above surface.

13. H. E. Cole estate, SE⿺ sec. 12, T. 21 S., R. 31 E. M. P., top of 3-inch casing, same altitude as surface.

14. L. A. Mos, about $0.1 \mathrm{mile}$ northeast of Slavia, east of road at Mos residence. D., McCollough. M. P., top of 3 -inch pipe, 2 feet above surface.

15. Andrew Duda, Sw $\frac{1}{4}$ sec. $16, \mathrm{~T}_{0} 21 \mathrm{~S}, \mathrm{R}_{0} 31 \mathrm{E}$, , near slavia. D., A. R. Arie. M. P., surface.

16. Martin Stanko, Slavia. M. P., surface.

17. J. E. Partin, 0.3 mile east of Econlockhatches River, on south side of Oviedo-Chuluota road. M. P., surface.

18. About $\ddot{2}, 5$ miles north of 0viedo, in canal leading to Lake Jessup. D., A. R. Arie.

19. NWT $\frac{1}{4} S E \frac{1}{4}$ Sec. $25, \mathrm{~T} .20 \mathrm{~S}, \mathrm{R}_{0} 31 \mathrm{E}$. (tract 376 ), east side of Stone Ave.

20. About 300 jards north of weil 19.

21. H. O. Crippen, lot 5, SW $\frac{1}{4} \mathrm{NW} \frac{1}{4}$ sec. 16, T. $20 \mathrm{~S}, \mathrm{R}, 31 \mathrm{E} .$, Sipes Ave.

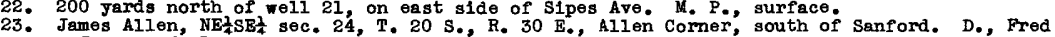
Jones. M., P., surface.

24. Brady, E. First'st., Sanford. M. P., top of 2-1nch pipe, 2.7 feet above surface.

25. North side of Celery Ave and west of St. Johns River bridge, Sanford. M. P., surface.

26. L. I. Frazier, Celery Ave., Sanford, near Frazier residence. M. P., top of $3 \% 4-1$ inch faucet, 1 foot above surface.

27. Union and Mellonvilie Aves., Sanford. M. P., surface.

28. About $0.4 \mathrm{mile}$ east of Wagner on north side of road. M. P. surface.

29. City of Sanford, city well $1,3.7$ miles south of Sanford city hall along highway 3 to 0 rlando. D., F. J. Raehn. M. P., surface.

30. E. Tenner, sec. Is, T. 2i's., R. 33 E. M. P., surface.

31. Woodmuff, $\mathrm{NE} \frac{1}{4}$ sec. 19, T. 19 S., R. 30 E., l. $_{*}$ miles west of Lake Monroe railroad station. M. P., surface.

32. J. E. Johnson, SE⿺ sec. 16, T. 19 S., R. 30 E., Lake Monroe. M. P., top of 2-1nch pipe, 1 foot above surface.

33. Carl Carlson, southwest intersection of lst St, and road to Lake Monroe. M. P., surface.

34. George McCrum, sec. 28, T. 19 S., R. 30 E., lst St., Sanford. M. P., surface. 
Records of wells in the Florida peninsula - Continued Owners, location, and driliers of the wells, description of the measuring points,
and remarks - Contimed

Sumter County

1. J. M. Brom, Oxford. D., W. Hamilton. M. P., top of 3-Inch casing, 0.1 foot above surface.

2. L. Bogue, Oxford M. P., surface.

3. Town of wildwood, Wildwood." M. P., top of 4-inch casing, I foot above surface.

4. Standard 011 Co. Wildwond. M. P.', top of 2-inch casing, 0.2 foot above surface.

5. Rus Crate Co., Coleman. M. P., top of 2 -inch casing, at surface.

6. 3. Stephens, about 6 miles north of Bushnell. D., S. Stephens. M. P., top of 10-1nch cesing,

7. S. Stephens, about 6 miles north of Bushnell. D., S. Stephens. M. P., top of $1-1$ inch plug in 6-inch coupling, 1.6 feet above surface.

8. Town of Bushnell, Bushnell. If. P., top of 6 -inch ell, 0.5 foot above surface.

9. Bushnell Ice Co., Bushnell. 1h. P., top of 4-inch tee on well, 0.5 foot above surface.

10. Town of Webster, Webster. M. P., top of 12-inch casing, 0.7 foot above surface.

11. George P. Parrish, about $4 \mathrm{miles}$ northeast of Richloam. M. P., top of 3-inch well tee, 1 foot above surface.

12. A. C. L., St. Catherine; U. S. E. D. 155. M. P., surface.

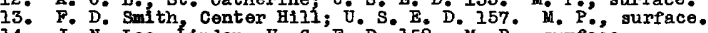

14. J. N. Lee, finden; U. S. E. D. 152. M. $P$, gurfece.

15. L. S. Brínson, sec. 25, T. 22 S., R. 22 B.; U. S. E. D. I53. M. P., surface,

Sumannee County

1. Town of Live 0ak, well 3, Live Oak. M. P., surface.

3. Town of Live Oak, well 2 , Live Oak. D., Wi. McGrew. M. P., surface.

4. Suwannee County, about 3.5 miles south of Live Oak. Uf. P., top of casing, same altitude as surface.

5. Town of Branford, Branford. M. P., surface.

6. H. H. Hair, about 3.5 miles north of LIve Oak, SW $\frac{1}{4} S E \frac{1}{4}$ sec. 36, T. I S., R. 13 E.; U. S. B. D. 89. M. P., surface.

7. J. Johnson, about 5.5 miles north of Live Oak, sec. 19, T. I S., R. 14 E.; U. S. E. D. 90.

8. J. W. L. Lassiter, Newburn; U. S. B. D. 82. M. P., surface.

9. F. M. Prevall, about 0.3 mile north of McAlpin,' SW $\frac{1}{4} S B \frac{1}{4}$ sec. 7, T. 4 S., R. 14 E.; U. S. E. D. 69. M. P., surface.

10. Standard Limber Co., Dowling Park; U. S. B. D. 75. M. P., surface.

1I. E. N. Poole, about 2 miles east of Dowling Park; U. S. B. D. 76. M. P., surface.

12. State Road Dept., sec. 33, T. 2 S., R. $14 \mathrm{E}$. Top of 5-1nch weli coupling, 0.5 foot above surm face.

Union County

1. Florida State Farm, about 3 miles north of Rafford. M. P., surface.

2. Forida State Farm, Ralford. D., Ohlo Well Drilling Co. M. P., base of water tank, 1 foot above surface.

3. Florida State Farm, Raiford. M. P., surface.

4. U. S. E. D., about 3.5 miles northeast of Raiford at New River Bridge. D., U. S. E. D. M. P., surrace.

5. U. S. E. D., Worthington Springs; U. S. E. D. 338. D., U. S. E. D. M. P., surface.

6. Gothe sawmill, Danville, sec. 2, T. 6 S., R. 19 B. M. P. top of $2 \frac{1}{2}-1$ inch casing, $i$ foot above surface.

7. J. W. Townsend, Lake Butler. W. P., top of 6-1nch casing, same altitude as surface.

\section{volusia county}

1. Town of De Land, In rear of post office, De Lend. M. P., top of pump pit, 21 feet above top of well casing and same altitude as surface.

2. Town of De Land, at city water plant, De Land. D., Layne Southeastern Co. M. P., surface.

3. Town of Lake Helen, Lake Helen. D., Gray Artesian' Well Co. M. P., surface.

4. Orange City Minerai Spring Co., Orange City. M. P., rim of pump pit, about same altitude as surface and 13.5 feet above top of caging.

5. W. J. Webber, about 3 miles northeast of Samsula, on south side of road to New Smyrna, $D_{\dot{*}}$, Wilson. M. $P_{\text {. }}$ surface.

6. J. B. Somerset, Oak fill. M. P., surface.

7. T. B. Lynch, east side of road to Sanford, 0.6 mile north of St. Johns River. H. P., top of 2 -inch pipe on well, 3 feet above surface.

8. Mrs. S. A. Baker, about 2 miles south of Seville, on west side of railroad and road. D., Ralph Vilis. M. P., top of 4-inch pipe, 3 feet above surface.

9. City of Daytona Beach, Daytona Beach. D., Melton. M. P., top of 2-1nch valve, 1 foot above surface. Reported loss of head is 8 feet since is8.

10. Town of Port Orange, Port Orange. D., S. Wilson. M. P., top of 6-inch valve, 1.5 feet above surface.

11. Experimental farm, about 2.5 miles west of New Smyrna. M. P., top of 2-inch ralve, 3 feet above surface.

12. Power plant of New Smyrna, New Smyrna. M. P., top of 4-inch casing, same altitude as concrete floor and surface. 13. Oak Hill Citrus Growerg Association, Oak Hill. D., S. Wilson. M. P., top of 2-inch tee, at
surface. 
Measurements of pressure heads and water levels in wells in the Florida peninsula

Whmbers designating the wells are the same as those in the table of well records. The pressure heads and water levels are expressed in feet above or belor the measuring point. A description of the measuring points is given in the notes following the table of well recordi. 7

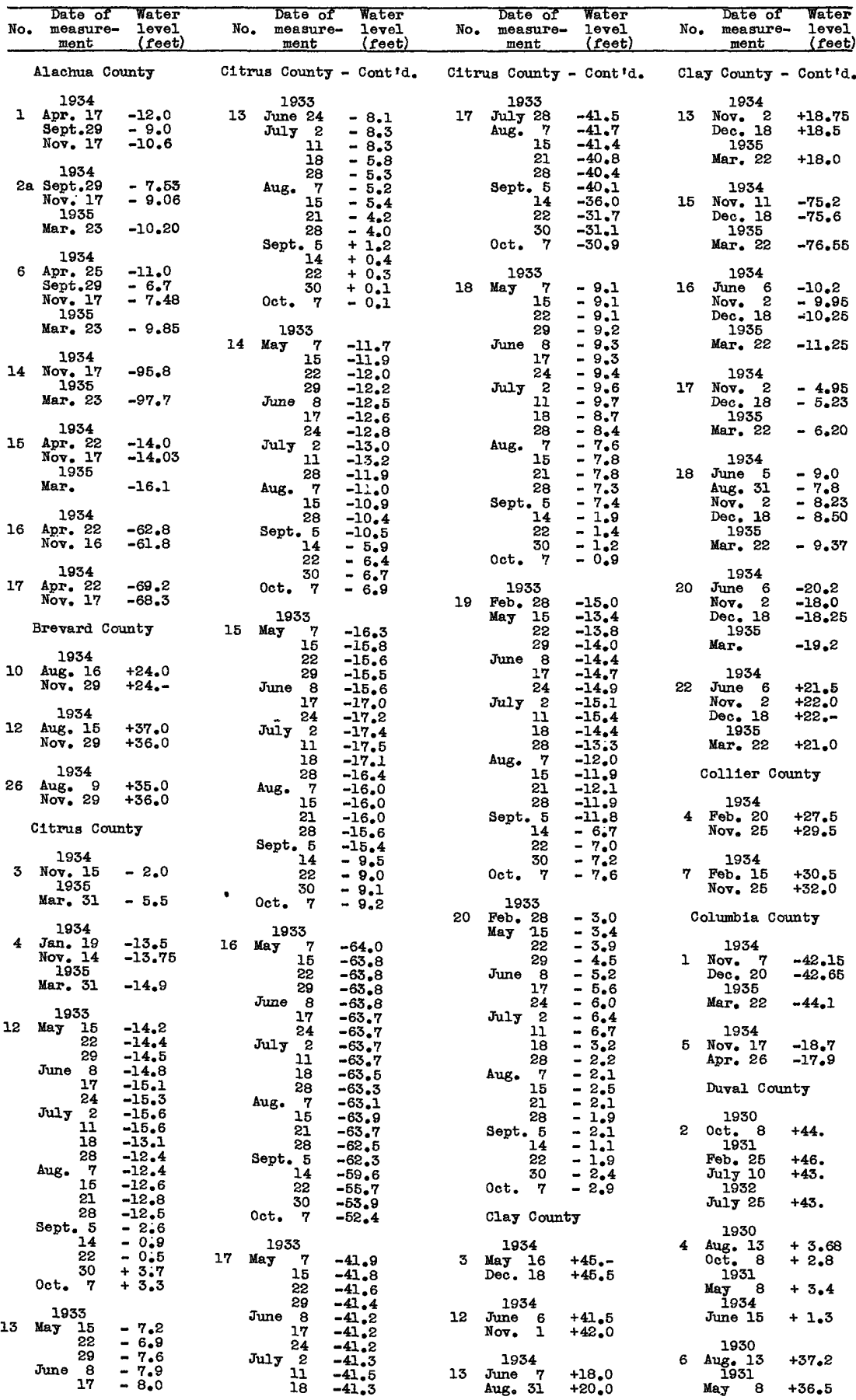


Heasurements of pressure heads and water levels in wells in the Florida peninsule - Contimued

\begin{tabular}{|c|c|c|c|c|c|c|c|c|c|c|c|}
\hline No. & $\begin{array}{l}\text { Date or } \\
\text { measure- } \\
\text { ment }\end{array}$ & $\begin{array}{l}\text { Water } \\
\text { level } \\
\text { (feet) }\end{array}$ & No. & $\begin{array}{l}\text { Date of } \\
\text { measure- } \\
\text { ment }\end{array}$ & $\begin{array}{l}\text { Water } \\
\text { level } \\
\text { (feet) }\end{array}$ & No. & $\begin{array}{l}\text { Date of } \\
\text { measure- } \\
\text { ment }\end{array}$ & $\begin{array}{l}\text { Water } \\
\text { level } \\
\text { (foet) }\end{array}$ & No. & $\begin{array}{l}\text { Date of } \\
\text { measure- } \\
\text { ment }\end{array}$ & $\begin{array}{l}\text { Water } \\
\text { level } \\
\text { (feet) }\end{array}$ \\
\hline
\end{tabular}

Dural County - Cont'd. Hermando County - Cont'd.

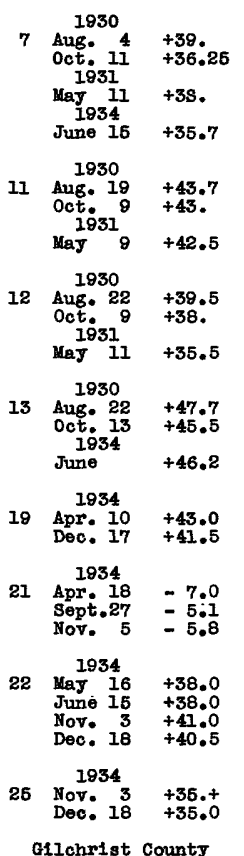

\section{$2 \quad \stackrel{1934}{\text { Apr. } 25}-42.5$ sept.29 -39.75 Nov. $17 \quad-40.92$ 1935 -43.0}

Hamilton county

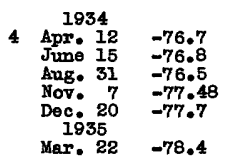

Hendry County

$\begin{array}{ll}1934 & \\ \text { Feb: } 12 & +28.0 \\ \text { Nov. } 11 & +27.5\end{array}$

Hernando County

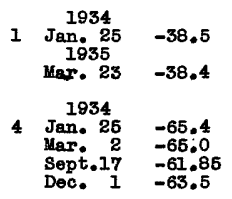

$8 \mathrm{Mar.}^{1934}-107$.

Sept.22 -103.07

Dec. $28-103.12$

$9 \operatorname{Jan}^{1934} 1-100 .+$ $\begin{array}{ll}\text { Jan. } 1 & -100 .+ \\ \text { Sept.17 } & -97.75\end{array}$ Dec. $\begin{array}{rr}28 & -97.7 \\ & -98.43\end{array}$ $451520-36$ - -6

\begin{abstract}
1935
\end{abstract}
9 Mar. $23-101.0$

H111sborough County

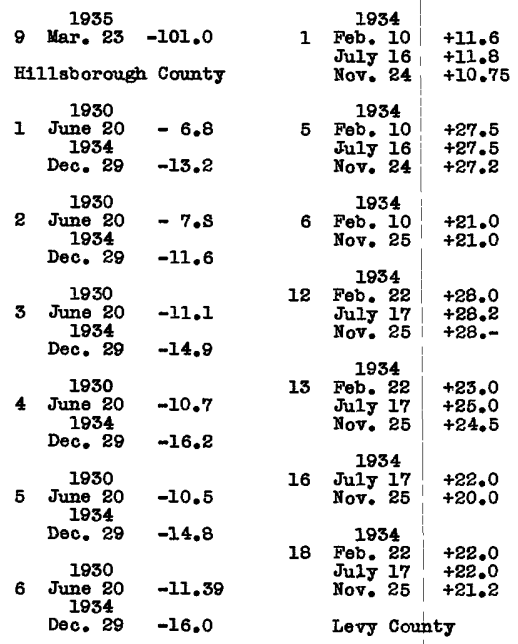

Dec. $29-16.0$

$7 \quad \begin{array}{ll}1930 \\ \text { Jume } 20 & -16.27\end{array}$

1934
Dec. $29-21.9$

1930

8 June $20 \quad-13.65$

1934
Dec. $22 \quad-18.4$

9 July $^{1930} 2-15.58$

1934
Jec. 29

$-20.9$

$10 \quad \begin{array}{ll}1930 \\ \text { June } 20 \quad-12.01\end{array}$

Doc. $29=-16.5$

1930

11 June $20 \quad-17.63$

1934
נec. $29-22.5$

1930

$12 \quad \begin{array}{cc}1930 \\ \text {.uly } 20 & -15.35\end{array}$

1)eo. 22

$-19.8$

13 oct. $2-7.0$

$\begin{array}{r}1934 \\ \text { Nov. } 2\end{array}-9.0$

$23 \begin{array}{cc}1934 \\ \text { Sept.21 } & -36.8\end{array}$

$\begin{array}{rr}28 & -34.8 \\ \text { Nov. } 27 & -36.1\end{array}$

Mar. $26 \quad-38.2$

28 Nov, $21 \quad-20.8$

$\begin{array}{ll}1935 & \\ \text { Mar. } 28 & -18.6\end{array}$

1934

27 Kov. 21

Mar. $28+1.75$

Iake County

1934

$5 \operatorname{Tan} 12-16.0$

Jun. $\frac{12}{27}-16.0$

1934

$6 \begin{aligned} & \text { Jan. } 12=E .5 \\ & \text { June } 27=3.5\end{aligned}$
Lee County

1834

Apr. $24 \mid-14.2$ 8ept.29 -11.67 \begin{tabular}{l|l} 
8opt.29 & -11.67 \\
Nov. 15 & -12.55
\end{tabular}

Mar. 23 -15.0

\begin{tabular}{cc|c} 
& 1934 & \\
2 & Sept.29 & -54.8 \\
& Nov. 15 & -55.7
\end{tabular} 1935

Mar. 28 -58.3

\begin{tabular}{c|c}
1934 & \\
Apr. 24 & -10.5 \\
Hov. 14 & -14.9
\end{tabular}

1932

10 8ept.30 -21.0

1933

Mar. $31-21.3$

May $15 \quad-18.2$

\begin{tabular}{r|r}
22 & -18.3 \\
29 & -18.3
\end{tabular}

June 8 - 18.4

\begin{tabular}{r|r}
24 & -18.6 \\
July 2 & -18.7
\end{tabular}

-18.7
-18.7

$-18.0$

28 - -16.0

Aug. 7 | -16.0

$21 \mid-16.0$

\begin{tabular}{l|l}
21 & -16.0 \\
28 & -16.0
\end{tabular}

Sept. 5 | -12.4

$-11.0$

$-11.0$

oct. $7 \quad-11.5$

11 \begin{tabular}{c|c}
1932 & \\
Sept.30 & -25.5
\end{tabular}

\begin{tabular}{l|l}
1933 & \\
May 15 & -23.1
\end{tabular}

\begin{tabular}{r|r}
22 & -23.1 \\
29 & -23.0 \\
\hline Jume & -23.0
\end{tabular}

Jume 8 -23.

\begin{tabular}{r|r}
24 & -23.2
\end{tabular}

$-23.3$

\begin{tabular}{l|l}
18 & -21.2 \\
28 & -20.8
\end{tabular}

Aug. $7-21.1$

\begin{tabular}{l|l}
15 & -21.2 \\
21 & -21.0
\end{tabular}

sept. $5 \quad-19.0$

\begin{tabular}{l|l}
14 & -17.6 \\
22 & -17.1
\end{tabular}
Levy County - Cont'd.

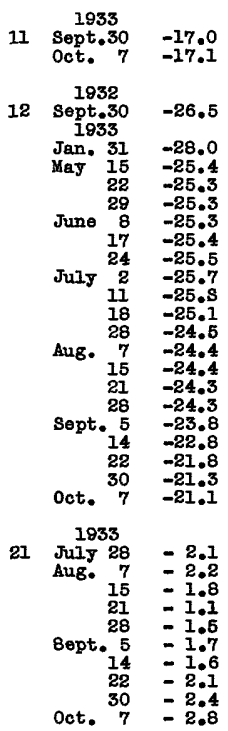

Manatee County

8 sept.26 +18.

Mar. $30+18.6$

June $10+17.4$

$\begin{array}{ll}11 & +17.7 \\ 11 & +17.4\end{array}$

1934

Jan. $23+16.3$

1931

15 May $28+11.5$

$\begin{array}{ll}\text { uay } 28 & +11.5 \\ \text { June } 10 & +10.3\end{array}$

Hay $28+17.9$

June $10+17.2$

II +17.2

$35 \quad \begin{aligned} & 1930 \\ & \text { Sept.24 } \\ & 1932\end{aligned} \div 1.0$

$\sin \theta 10+1.0$

39 Sept.27 + 1.4

June $10+2.35$

1931

Apr. $7+6.3$

June $15+3.7$

$\operatorname{Jan}_{*}^{1932} 8+5.9$

43 Sept.30 +9.5

Apr. $8+9.8$
Juni $10+6.7$

1932

Jan. $8+8.0$

ob. $11+5.4$

Kar. $11+5.4$

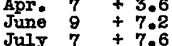

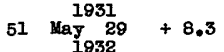

Jan. $8+3.0$
Feb. $11+4.3$ 
Measurements of pressure heads and water levels in wells in the Florida peninsula - Continued

\begin{tabular}{|c|c|c|c|c|c|c|c|c|c|c|c|}
\hline No. & $\begin{array}{l}\text { Date of } \\
\text { measure- } \\
\text { ment }\end{array}$ & $\begin{array}{l}\text { Water } \\
\text { level } \\
\text { (feet) }\end{array}$ & No. & $\begin{array}{l}\text { Date of } \\
\text { measure- } \\
\text { ment }\end{array}$ & $\begin{array}{l}\text { Water } \\
\text { level } \\
\text { (feet) }\end{array}$ & No. & $\begin{array}{l}\text { Date of } \\
\text { measure- } \\
\text { ment }\end{array}$ & $\begin{array}{l}\text { Water } \\
\text { level } \\
\text { (feet) }\end{array}$ & No. & $\begin{array}{l}\text { Date of } \\
\text { measure- } \\
\text { ment }\end{array}$ & $\begin{array}{l}\text { Water } \\
\text { level } \\
\text { (feet) }\end{array}$ \\
\hline
\end{tabular}

Manatee County - Cont'd. Marion County - Cont'd. Marion Gounty - Cont'd. Marion County - Contid.

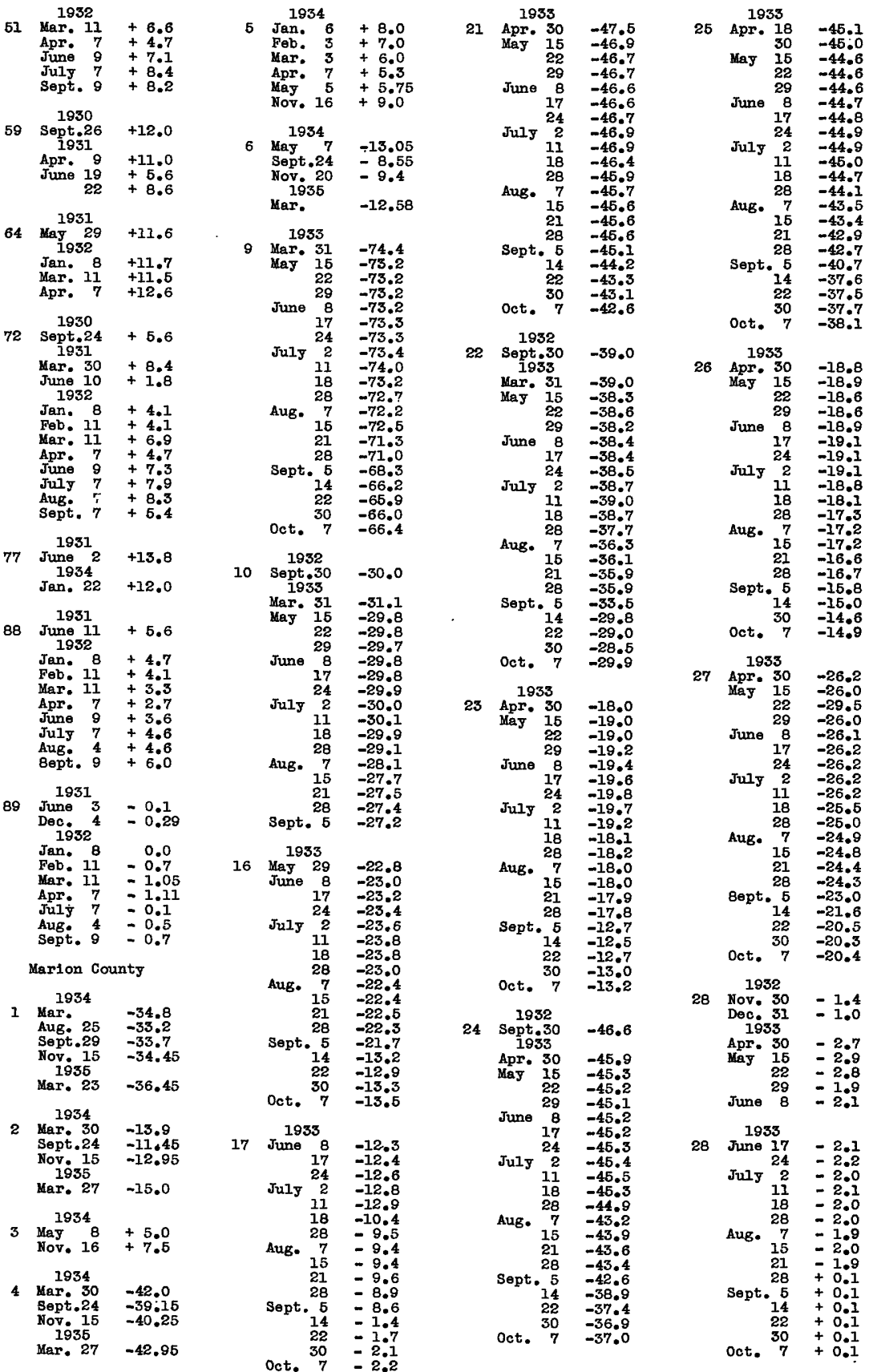


Messurements of presgure heal and water levels in wells in the Florida peninsula - Continued

\begin{tabular}{|c|c|c|c|c|c|c|c|c|c|c|c|}
\hline No. & $\begin{array}{l}\text { Date of } \\
\text { measure- } \\
\text { ment }\end{array}$ & $\begin{array}{l}\text { Water } \\
\text { level } \\
\text { (feet) }\end{array}$ & No. & $\begin{array}{l}\text { Date of } \\
\text { measure- } \\
\text { ment }\end{array}$ & $\begin{array}{l}\text { Water } \\
\text { level } \\
\text { (feet) }\end{array}$ & No. & $\begin{array}{l}\text { Date of } \\
\text { messure- } \\
\text { ment }\end{array}$ & $\begin{array}{l}\text { Water } \\
\text { level } \\
\text { (feet) }\end{array}$ & No. & $\begin{array}{l}\text { Date of } \\
\text { measure- } \\
\text { ment }\end{array}$ & $\begin{array}{l}\text { Water } \\
\text { level } \\
\text { feet }\end{array}$ \\
\hline
\end{tabular}

Marion County - Cont'd. Marion County - Cont'd. Orange County - Cont'd. Orange County - Cont'd.
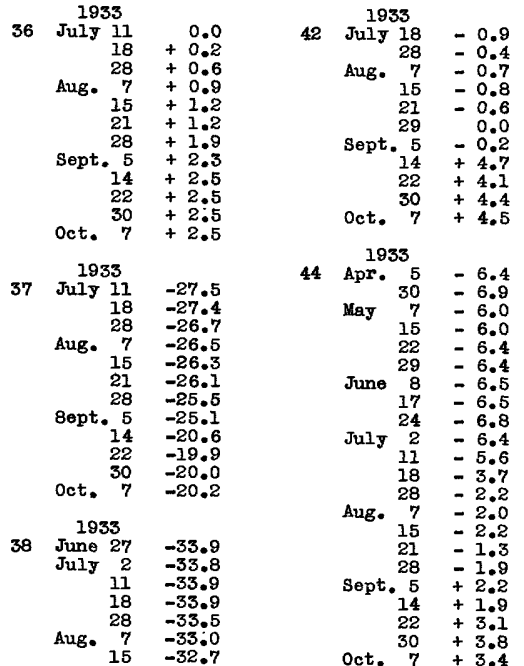

$$
\begin{array}{rr}
15 & -32.7 \\
21 & -32.4 \\
28 & -31.7 \\
5 & -31.3 \\
14 & -26.6 \\
22 & -25.6 \\
30 & -25.6 \\
\text { Oct. } 7 & -25.0
\end{array}
$$$$
39 \quad 1933
$$$$
39 \text { July } 2-30.0
$$$$
\begin{array}{ll}
11 & -30.1 \\
18 & -30.0
\end{array}
$$$$
\text { Aug. } 7
$$$$
-29.4
$$$$
\text { Aug. } 7 \quad-28.6
$$$$
-28.4
$$$$
\begin{array}{ll}
21 & -28.1 \\
28 & -27.1
\end{array}
$$$$
\text { Sept. } 5 \quad-26.8
$$$$
-21.6
$$$$
\begin{aligned}
& -21.6 \\
& -20.9 \\
& -20.9
\end{aligned}
$$$$
\text { oct. } \begin{array}{rr}
30 & -20.9 \\
& -21.1
\end{array}
$$

$$
42 \text { July } 18 \quad-0.9
$$

$\begin{array}{rr}\text { July } 18 & -0.9 \\ 28 & =0.4 \\ 7 & -0.7 \\ 15 & -0.8 \\ 21 & -0.6 \\ 29 & 0.0 \\ \text { Aug. } & -0.2 \\ 14 & +4.7 \\ 22 & +4.1 \\ 30 & +4.4 \\ \text { Sept. } & 74\end{array}$

$$
44 \text { Apr. } 5 \text { - } 5.4
$$

$$
\text { May } \begin{aligned}
30 & -6.9 \\
& -6.0
\end{aligned}
$$$$
\text { May } \begin{aligned}
7 & -6.0 \\
15 & -6.0
\end{aligned}
$$$$
\begin{aligned}
22 & -6.4 \\
29 & -6.4
\end{aligned}
$$$$
\text { June } \begin{aligned}
8 & =6.5 \\
17 & =6.5
\end{aligned}
$$$$
\text { July } \begin{aligned}
24 & =6.8 \\
2 & =6.4 \\
17 & =5.6
\end{aligned}
$$$$
\begin{aligned}
& 11=5.6 \\
& 18=3.7
\end{aligned}
$$$$
28-2.2
$$$$
\begin{aligned}
& 75-2.2 \\
& 215
\end{aligned}
$$$$
21-1.3
$$$$
\text { Sept. } 5+2.2
$$$$
\begin{aligned}
& 14+1.9 \\
& 22+3.1
\end{aligned}
$$$$
\text { oct. } 7+3.4
$$

Martin county

$\begin{array}{ll}\text { Mar. } 2 & +42.0 \\ \text { Nov. } 29 & +45.0\end{array}$

Nassau County

1934

8 Mar. $16+42.0$

Dec. $18+42.0$

12. $\begin{array}{ll}\text { Mar. } 17 & +46.0 \\ \text { Dec. } 18 & +45.0\end{array}$

16) $\begin{array}{cc}1934 & \\ \text { Apr. } 17 & +42.0 \\ \text { Dec. } 18 & +43.2\end{array}$

Ukeechobee County

1933
$\therefore \quad$ Apr.24 $24+12.0$

$$
\text { Feb. } 15+18.0
$$

$$
\text { Orange county }
$$

1930

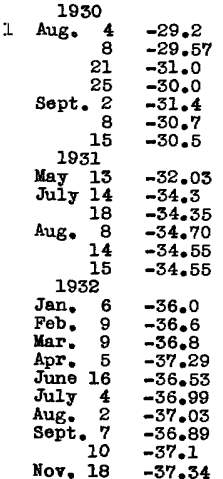

1934
Mar. 5
Dec. $17=4: 3$

$$
\begin{aligned}
& 1933 \\
& \text { May } 11 \quad-38.75 \\
& \text { Nov. } 28 \quad-38.9 \\
& \begin{array}{ll}
1934 & -35.8
\end{array} \\
& \text { Mar. } 21 \quad-30.3 \\
& \text { May } 17 \quad-34.2 \\
& \text { June } \begin{array}{rr}
18 & -27.9 \\
19 & -28.4
\end{array}
\end{aligned}
$$$$
1930
$$$$
2 \text { Aug. is }-30.7
$$$$
213 \quad-30.9
$$$$
\text { Sept. } 25 \quad-31.8
$$$$
8 \quad-32.1
$$$$
1931-32.8
$$$$
\text { July } 14 \quad-35.8
$$$$
\text { Aug. } 8 \quad-36.2
$$$$
\begin{array}{cc}
1933 \\
\text { May } 11-40.2
\end{array}
$$$$
1930
$$$$
3 \text { Aug. } 4 \quad-31.0
$$$$
\text { Aug. } \begin{array}{ll}
4 & -31.0 \\
8 & -31.37
\end{array}
$$$$
\begin{array}{rr}
21 & -32.0 \\
\hline 5 & -32.0
\end{array}
$$$$
\text { Sept. } 2 \quad-33.2
$$$$
\begin{aligned}
15 & -32.4 \\
15 & -33.10
\end{aligned}
$$$$
\text { Aug. } 8 \text {-36.5 }
$$$$
4 \text { Aug. } 6
$$

$$
\text { Aug. } \begin{array}{ll}
6 & -38.4 \\
8 & -37.48 \\
21 & -39.0 \\
25 & -38.7 \\
\text { Sept. } & -40.0 \\
2 & -39.0 \\
8 & -39.9 \\
15 & -39
\end{array}
$$$$
1931
$$$$
-43.6
$$$$
\begin{aligned}
& -43.6 \\
& -43.95
\end{aligned}
$$$$
\begin{aligned}
& -43.95 \\
& -43.70
\end{aligned}
$$$$
\begin{aligned}
& -43.70 \\
& -43.70
\end{aligned}
$$$$
1932^{75}
$$$$
1932
$$

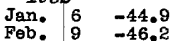

$\begin{array}{ll}\text { Meb. } 9 & -46.2 \\ 9 & -45.6\end{array}$

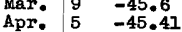

Sept 10

Aug. $2 \quad-45.78$

Sept. $7 \quad-45.86$

ov. 18

May $11 \quad-47.5$

1930

5 Aug. $\frac{5}{8}$

$-35.71$$$
\begin{aligned}
& -36.03 \\
& -37.8
\end{aligned}
$$$$
-37.8
$$

sept. $\begin{array}{ll}25 & -37.35 \\ 2 & -38.7\end{array}$

$1931^{8} \quad-39.1$

July 13

Aug. $8 \quad-42.4$

-42.75
-42.40

$\begin{array}{ll}14 & -42.40 \\ 15 & -42.35\end{array}$

Sept.10 $\quad-45.00$

May $11 \quad-46.6$

1930

6 Aug. $\left[\begin{array}{ll}5 & -39.0 \\ 8 & -37.58\end{array}\right.$

1931

July $13 \quad-44.0$

Aug. $\begin{array}{ll}21 & -43.6 \\ & -44.3\end{array}$

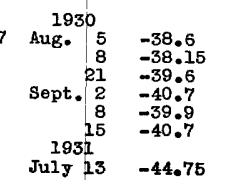

1931

Aug. $8 \quad-45.00$

$\begin{array}{ll}14 & -44.70 \\ 15 & -44.70\end{array}$

$\begin{array}{cc}1932 & \\ \text { Sept.10 } & -47.55\end{array}$

Sept 1933

May $11-49.2$

Nov. $27 \quad-45.0$

1934

May $18-43.9$

June $16 \quad-31.7$

$18 \quad-35.7$

$\begin{array}{ll}19 & -36.5 \\ 20 & -37.2\end{array}$

$\begin{array}{ll}21 & -37.7 \\ 23 & -37.8 \\ 26 & -38.7\end{array}$

8 Aug. $8 \quad-35.00$

$\begin{array}{ll}\text { Aug. } 8 & -35.00 \\ \text { Sept. } 2 & -37.5 \\ 8 & -38.0\end{array}$

$\begin{aligned} 15 & -38.0 \\ 1937 & -37.55\end{aligned}$

July $23-47.3$

Aug. $8 \quad-40.65$

Aug. $\begin{array}{rr}8 & -41.50 \\ 14 & -41.25\end{array}$

$1933^{15}-41.20$

May $10 \quad-45.85$

June $18 \quad-35$.

1930
Aug. 8
$15=1.20$
$15=0.4$
Sept. $2=4.0$
$15=3.8$

1930

10 Aug. $4-3.53$

Sept. $8=4.73$

Sept. $\begin{array}{r}2=7.50 \\ 8=5.50\end{array}$

$15=7.30$

May $\begin{aligned} 1 & -9.1 \\ 13 & -8.9\end{aligned}$

$\begin{array}{lll} & 15 & -9.42 \\ \text { July } & 10 & -11.6 \\ 13 & -11.8\end{array}$

$-11.8$

$-11.45$

Aug. $5 \quad-11.8$

$-11.85$

$-11 \cdot 9$

$-11.2$

$1932^{18}$

Jan. $6-13.23$

$-14.05$

Apr. $5 \quad-13.95$

June -14.20

July $14 \quad-13.9$

Aug. 2 -13.:

Nov. $\begin{aligned} 10 & -14.1 \\ 18 & -14.57\end{aligned}$

1933

$25 \quad-16.0$

Nov. $\begin{array}{ll}24 & -11.8 \\ 28 & -12.0\end{array}$

Jan. $4 \quad-12.4 \pm$

Jan. $4 \quad-12.4$

$19=2.5$
$26=4.7$

1930

11 AUE. $5 \quad-32.8$

$\begin{aligned} 8 & -32.57 \\ 21 & -34.3 \\ \text { Sept. } 2 & -35.1 \\ \text { 1931 } & \\ \text { Aug. } 8 & -39.25 \\ 14 & -38.90 \\ 15 & -38.90\end{aligned}$


Measurements of pressure head and water levels in wells in the Florida peninsula - Contimued

\begin{tabular}{|c|c|c|c|c|c|c|c|c|c|c|}
\hline No. & $\begin{array}{l}\text { Date of } \\
\text { measure- } \\
\text { ment }\end{array}$ & $\begin{array}{l}\text { Water } \\
\text { level } \\
\text { (feot) }\end{array}$ & No. & $\begin{array}{l}\text { Date of } \\
\text { measure- } \\
\text { ment }\end{array}$ & $\begin{array}{l}\text { Water } \\
\text { level } \\
\text { (feot) }\end{array}$ & No. & $\begin{array}{l}\text { Date of } \\
\text { measure- } \\
\text { ment }\end{array}$ & $\begin{array}{l}\text { Water } \\
\text { level } \\
\text { (fort) }\end{array}$ & No. & $\begin{array}{l}\text { Date or } \\
\text { measure- } \\
\text { ment }\end{array}$ \\
\hline
\end{tabular}

Orange County - Cont'd. Orange County - Cont'd. Oxange County - Cont'd. Orange County - Cont'd.

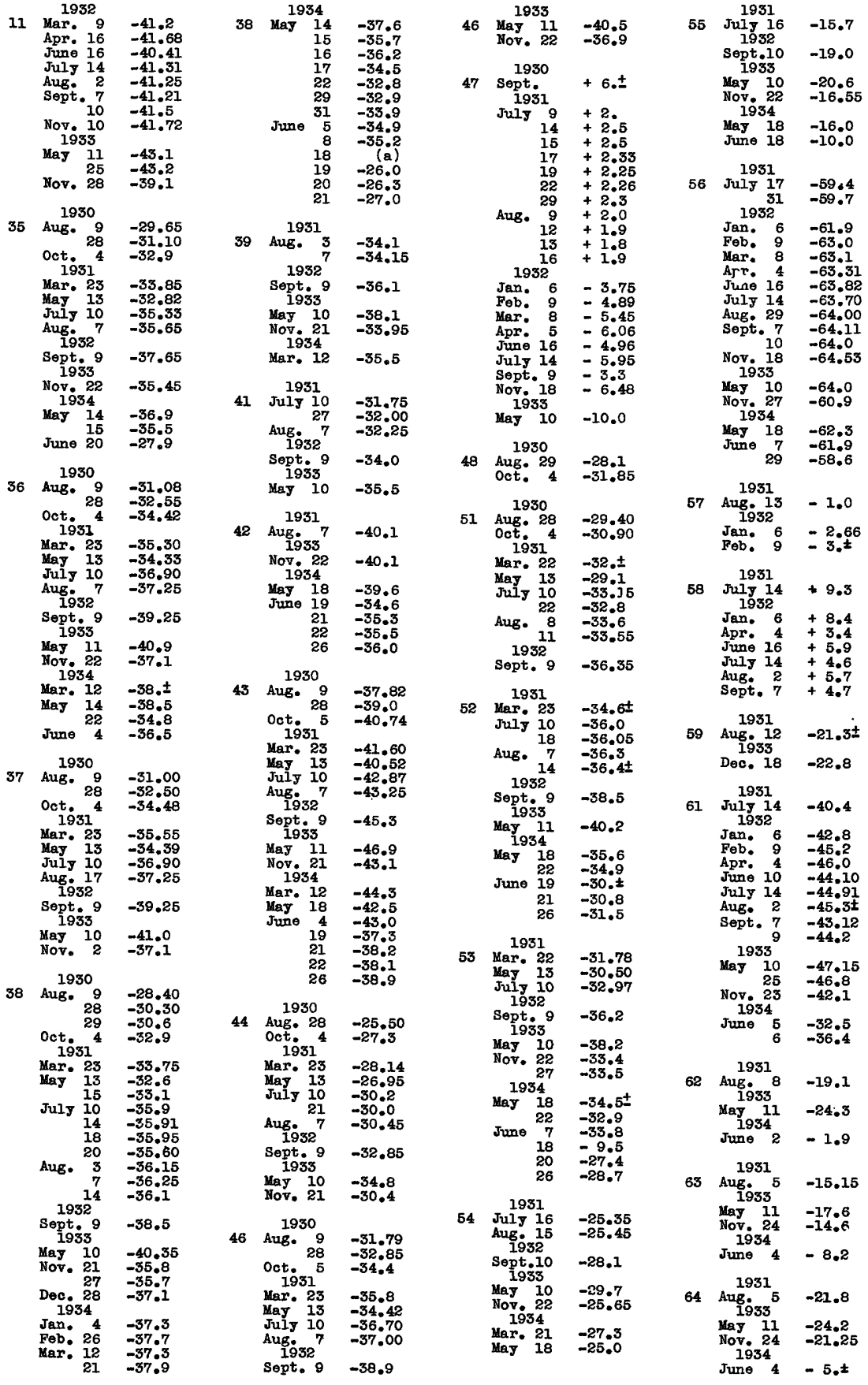

a/ Well spouting. 
Measurements of pressure head and water levels in wells in the Florida peninsula - Continued

\begin{tabular}{|c|c|c|c|c|c|c|c|c|c|c|c|}
\hline 0. & $\begin{array}{l}\text { Date of } \\
\text { measure- } \\
\text { ment }\end{array}$ & $\begin{array}{l}\text { Water } \\
\text { level } \\
\text { (feet) }\end{array}$ & No. & $\begin{array}{l}\text { Date of } \\
\text { measure- } \\
\text { ment }\end{array}$ & $\begin{array}{l}\text { Water } \\
\text { level } \\
\text { (feet) }\end{array}$ & No & $\begin{array}{l}\text { Date of } \\
\text { measure- } \\
\text { ment }\end{array}$ & $\begin{array}{l}\text { Water } \\
\text { level } \\
\text { (feet) }\end{array}$ & No & $\begin{array}{l}\text { Date of } \\
\text { measure- } \\
\text { ment }\end{array}$ & $\begin{array}{l}\text { Water } \\
\text { level } \\
\text { ( foet) }\end{array}$ \\
\hline
\end{tabular}

Orange County - Cont'd. Polk County - Cont'd.

\begin{tabular}{|c|c|c|}
\hline & 1933 & \\
\hline 65 & May & -22.6 \\
\hline 66 & $\begin{array}{c}1933 \\
\text { Nov. } 28\end{array}$ & +7.1 \\
\hline & Pasco Con & nty \\
\hline 9 & $\begin{array}{c}1934 \\
\text { Jan. } 16 \\
\text { Sept.17 } \\
28\end{array}$ & $\begin{array}{l}-15.8 \\
-10.1 \\
-10.4\end{array}$ \\
\hline 10 & $\begin{array}{c}1934 \\
\text { Jan. } 16 \\
\text { Sept.17 }\end{array}$ & $\begin{array}{l}-9.3 \\
-3.6\end{array}$ \\
\hline 13 & $\begin{array}{c}1934 \\
\text { Kar.14 } \\
\text { Sept_28 }\end{array}$ & $\begin{array}{r}-7.75 \\
-5.35\end{array}$ \\
\hline
\end{tabular}

$3 \quad 1934$

Mar. $16-18$.

$\begin{array}{ll}\text { July } 20 & -16.9 \\ \text { Sept.14 } & -17.17\end{array}$

Sept.14 $\begin{aligned} &-17.17 \\ & 26-17.47\end{aligned}$

Nov. $20 \quad-18.4$

$\begin{array}{ll}1935 & \\ \text { Mar. } 25 & -19.6\end{array}$

1934

4 Mar. $17-24.0$

Suly $20 \quad-19.0$

Sept.14 -18.75

Nov. $20 \quad-19.90$

$\begin{array}{ll}1935 \\ \text { Mar. } 25 & -21.43\end{array}$

1034

7 Jan. $10-6.3$

July $20=5.0$

Sept.14 - 5.78

1934

8 JuIy $20=7.1$

Sept. $14=7.85$

Hov. $20 \quad-8.95$

Mar. $25-12.5$

$11 \quad \begin{array}{ll}1934 \\ \text { Mar. } 15 & -97.0\end{array}$

July $19 \quad-95.3$

Sept.12 -95.75

$\begin{array}{ll}19 & -95.17 \\ 28 & -95.27\end{array}$

Nov, $22 \quad-97.78$

1935

Har. $25 \quad-99.50$

1934

$15 \quad \begin{array}{ll}1934 \\ \text { Mar. } 15 & -13.0\end{array}$

July $19 \cdot-11 \cdot 1=$

Sept.14 -11.7

$\begin{array}{ll}19 & -11.73\end{array}$

Nov. $20 \quad-13.5$

Mar. $28 \quad-14.75$

$18 \quad 1934$

Juiy 20 - 7.1

8ept.14 -7.5

Nov. $20=9.05$

1935

Har. 25

$-10.8$

22

1934

July $23-50.15$

Sept.15 -50.5

$26 \quad-50.6$

Ov. 21

$-52.13$

Mar. 26

$-54.17$

1934

24 Sept.13

Nov. 21

-14.25
-14.57

-14.57
-16.53

1935
$\operatorname{Mar} .28$

$-18.4$
1934

27 Sept.13 -29.5

Nov $26 \quad-29.85$

Nov. 21

Mar. $26 \quad-34.4$

1934

$\begin{array}{rr}\text { Sept.15 } & -33.85 \\ 26 & -33.95\end{array}$

Nov. $22 \quad-34.3$

1935

Mar. $25-36.0$

1934

32 sept.20 -6.15

Nov, $21=\begin{array}{ll}26 & -6.90 \\ & -8.65\end{array}$

Nov. 21

Mar. 26

.0 .65

1934

34 July $26 \quad-2.3$

Sept.15 -2.45

$1935-2.82$

$\operatorname{Max} .26-6.25$

35 Nov. $22 \quad-62.77$

Mar. $26-64.7$

1934

$36 \mathrm{Jan} 9$

July $23 \quad \mathbf{- 4 7 . 0}$

sept.13 -44.25

$\begin{aligned} \text { 8ept.13 } & -44.26 \\ 26 & -44.6\end{aligned}$

Nov. 21

1935

$-48.2$

$\begin{array}{ll}\text { Jan. } 9 & -42.8 \\ \text { Ju1y } 23 & -39.8\end{array}$

Sept.13 $\quad-40.03$

$\begin{array}{ll}26 & -40.4 \\ \text { Hov. } 21 & -41.98\end{array}$

1935

Har. 25

$-44.70$

1934

38 Hov. 22 -49.81

Mar. $25-52.2$

9 Jan. $5+11.2$

Sept.20 +13.3

Hov. $21+12.9$

1935

uar. $25+9.0$

$41 \begin{gathered}1934 \\ \text { Sept.21 } \\ \text { Nov. } 21+1.1\end{gathered}$

Putnam County

1934

12 May $8+20.0$

Dec. $1+20.0+$

Mar. $22+20.0-$

1934

14 Apr. 22 $\quad-34.3$

Nov. $16 \quad-30.05$

Mar. $22 \quad-31.5$

1934

20 May $9 \quad-20.8$

.

1934

10 Aug. $31+20.0$

Nov. $4+19.5$
JuIy $24-33.4$

$37 \quad \operatorname{Jan}^{2934} 9$

1934
St. Irucie county

\begin{tabular}{cc|c}
1 & $\begin{array}{c}1934 \\
\text { Mar. } 13\end{array}$ & +31.0 \\
1935 & & \\
Mar. 28 & +27.5 \\
& 1934 & \\
& Mar. 23 & +26.0 \\
& Nov.29 & +28.25 \\
1935 & +25. \\
& Mar. 28 & +25. \\
& Seminole & County
\end{tabular}

1923

1 May $13+4.25$

Dec. $4+7.80$

1934

June $4+7.2$

1933

May $18+0.9$

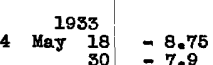

Dec. \begin{tabular}{r|l}
50 & $=7.9$ \\
& $=6.4$
\end{tabular}

$\begin{aligned} & \text { Mag } 19 \\ & \text { Dec. } 4\end{aligned} \mid+7.0$

7933

6 May 15

1933

May $18+20.0$

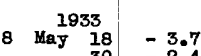

9 \begin{tabular}{rr|l}
1933 & \\
May & 28 & +0.65 \\
30 & +1.4
\end{tabular}

10 May 26

10 May 30
+8.5

$11 \mathrm{Mag}^{1933} 15 \mid+0.7$

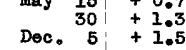

$12 \mathrm{Mag}^{1933} 26 \mid+4.8$

Dec. \begin{tabular}{r|r}
30 & +5.5 \\
5 & +5.5
\end{tabular}

1933

13 May 26 + 3.6

Deo. $\begin{aligned} 30 & +4.6 \\ 5 & +5.25\end{aligned}$

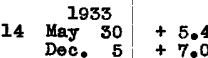

1933

24 May $24+10.0$

28 \begin{tabular}{c|c}
1930 & \\
Aug. 25 & +15.5
\end{tabular}

uay $13+14.1$

Aug. $15+12.6$

1932

Jan. 5

Feb: 8 +10.0

Mar. $7+11.5$

Apr. 4 +10.6

July 14 ti

Aul 140

$\begin{array}{ll}\text { Aug. } 1 & +11.0 \\ \text { Sept. } 6 & +11.0\end{array}$

1935

$32 \quad \operatorname{May}^{1935} 26 \quad+15.25$
Sumter county

1934

1 Mar. 29

Nov. $25 \quad-76.5$

1935

Mar. $27 \quad-77.95$

1934

3 Mar. $27 \quad-10.75$

Sept.22 - 7.2

Nov. $20-7.64$

Mar. $27-10.63$

1934

$7 \operatorname{Mar}_{0} 27 \quad-15.9$

Nov. $20 \quad-14.00$

1934

10 far. $26-10.5$

Sept.22 $\quad-6.77$
Nov. $20 \quad-8.6$

Nov. $20-8.6$

Mar. $28 \quad=10.6$

Suwannee County

$4 \quad \begin{array}{ll}1934 \\ \text { Apr. } 26 \quad-66.1\end{array}$

May $25 \quad-87.0$

Nov. $77-62.0$

Dec. $\begin{array}{ll}17 & -62.18 \\ & -64.0\end{array}$

1935

$\begin{array}{ll}\text { Har. } 3 & -64.7\end{array}$

1934

Aug. $27-5.2$

oct. $28-6$.

Union County

$\begin{array}{lll} & 1934 \\ \text { Nov. } 26 & -79.67\end{array}$

Deo. $21 \quad-80.3$

1935

Max. $22-80.8$

1934

7 Nov, $7 \quad-58.6$

Doc. $20 \quad-59.3$

1935
Mar. $22 \quad-59.87$

Volusia 0ounty

8 \begin{tabular}{ll}
\multicolumn{2}{c}{1934} \\
May 23 & +9.5 \\
Doc. 3 & +8.33
\end{tabular} 